Shes a

Heng

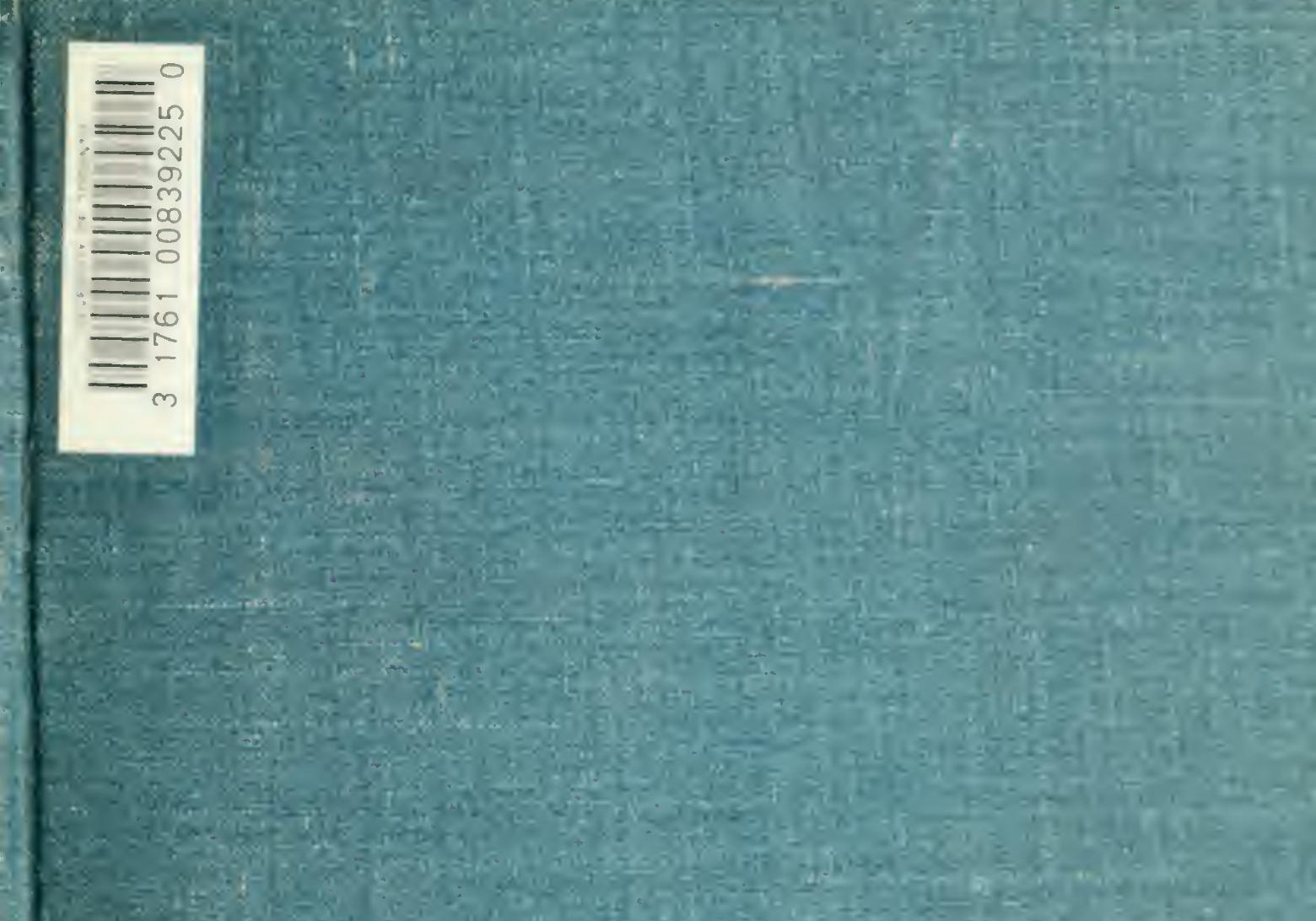

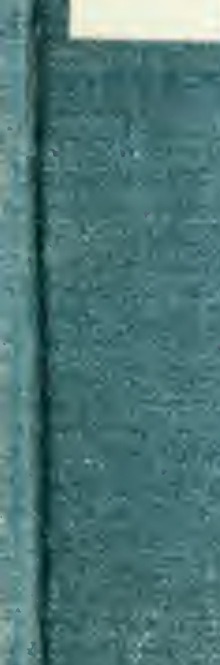
$2, \frac{1}{2}$

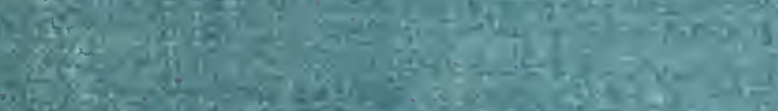

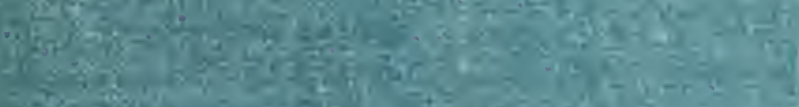

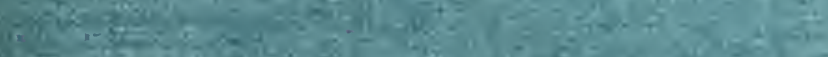

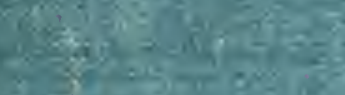

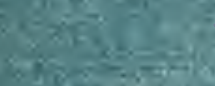
wis.

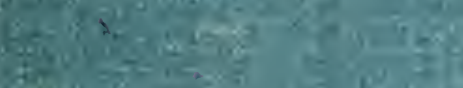

UMY n Toboryo LIBRARY 

. 
Digitized by the Internet Archive in 2008 with funding from Microsoft Corporation 


\title{
REVERSION IN GUINEA-PIGS AND ITS EXPLANATION
}

\author{
BY W. E. CA STIE
}

\section{EXPERIUENTAL STUDIES OF TIIE INHERITANCE OF COLOR IN MIICE}

\author{
B Y C. C. LI T T L E
}
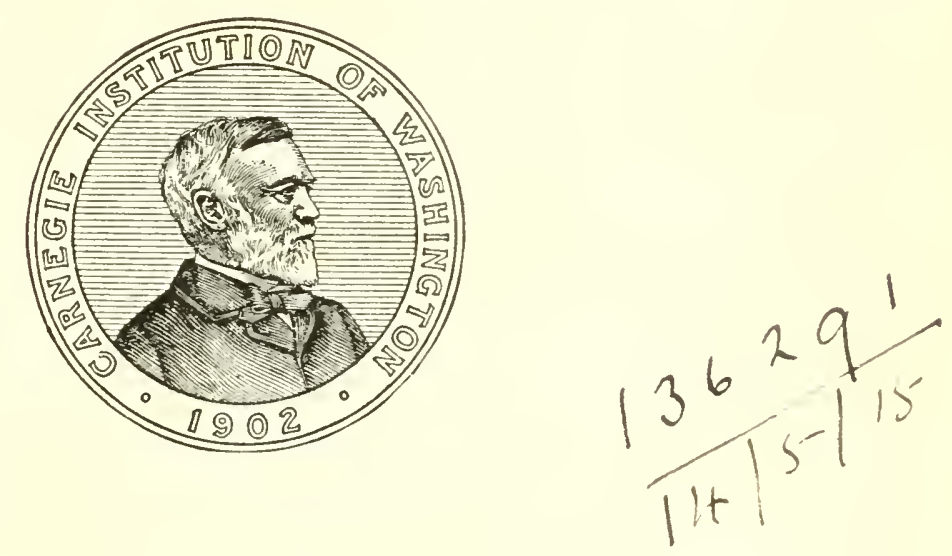

WASHINGTON, D. C.

Published by the Carnegie Institution of Washington 


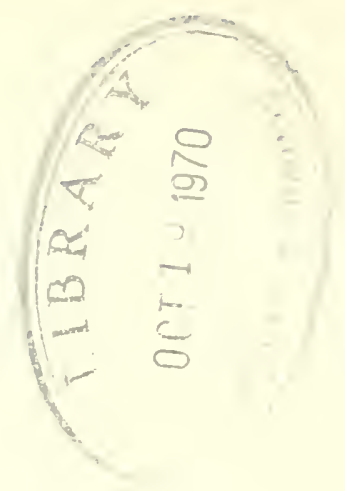

Carnegie intitetion of Masmigton. Publicition No. 179.

Papirs Nos. 19 and 19 of the śtation for Expermental. Gyolvtion at Cold spring HaRbor, New York.

\author{
Coptes of this Book \\ were first issued \\ SEP 131913
}

IRESS OF GIBSON BROTHF.RS

WASHINGTON, D. C. 


\title{
REVERSION IN GUINEA-PIGS AND ITS EXPLANATION.
}

\author{
By W. E. CASTLE.
}

Professor of Zoology in Harverd L'niversity.

Resparch Assoriate of the Crarnegic Institution of IFaslington.

Paper No. 18, Station for Exprimentul Erolution at Coht spring Harbor, Now Fork. 


\section{REVERSION IN GUINEA-PIGS ANB) ITS EXPLANATION.}

In 1905 I showed that when black-coated guinea-pigs of pure race are mated with red-coated ones only black-coated young are ordinarily produced, and that if such young are in turn mated with reds, both black young and red ones are obtained. In other words, black is a mendelian dominant to red. The fact was, however, noted that occasionally the cross of black with red causes reversion to the agouti or wild type. But this may be regarded as a modified condition of black, since the hairs of the agouti animal contain black pigment, but disposed in a definite pattern with red, the entire hair being black except a terminal or subterminal band of red (or yellow).

An examination of the tables of matings published at that time shows that all the agouti animals so produced were the progeny of a single red animal, $\sigma^{7} 2054$. This animal produced black young as well as agouti ones in crosses with black, so it was not clear to what the reversion was due. By a study of the progeny of this animal the matter was later cleared up. The black young were found never to produce agouti young in crosses with any red animals unless such reds were descended from o' 2054. The agoutis, however, produced a mixture of agoutis, blacks, and reds, when mated with ordinary red animals.

These and other corroborating experiments, reported briefly in 1907, showed that the agouti reversion in crosses of black with red is due to a factor transmitted by the red parent, never by the black one. For, as I then showed: (1) a red animal which produces the reversion to agouti in crosses with one black animal will produce it in crosses with any black animal; but (2) no black animal will produce agouti young unless crossed with a red animal which also produces agouti young in crosses with other black animals.

For simplicity, the something possessed by red animals which induces reversion, I have called the agouti or $A$ factor. It is invisible in the red animal, since the hairs of such animals are red throughout their length. Its only discoverable function is to exclude black from the terminal portion of the hair, and this function plainly can not be exercised unless black pigment is present. Now this agouti factor is transmitted like any other simple independent mendelian factor. Some reds are homozygous in $A$ and so transmit it in all their gametes. A very fine female of this sort, lindly loaned me in the summer of 1906 by Mr. B. B. Horton, was mated with two different black males ( 54565 and $\sigma^{7} 9538$ ), by each of which she bore five young, all agouti-marked. These same males when mated to other red females produced only black young.

Most of the agouti-producing reds which I have had, including the original or 2054 (received in June, 1903) and some of his descendants, have been heterozygous in the agouti factor, so that when mated with black animals they produced in approximately equal numbers agouti young and black ones. All 
reds which I have had, derived from other sources than these two, have failed to produce agouti young in crosses with black animals; see the summary in table 1, p. 8. They may therefore be considered to lack altorether the agouti factor in which wild species of cavy are regularly homozygous.

The agouti factor is transmitted through albinos exactly as are other color factors. Accordingly an albino may or may not possess and transmit the agouti factor; if it cloes possess this factor, it will produce agouti offspring when crossed with a black animal. Several examples of this have been observed among the albino deseendants of o 2054 . Thus red $0^{3} 3496$, table 1 , which when mated with heterozygous black females produced red young and black ones but no agoutis, when later mated with the albino females 4270 and 4262 produced 4 red and 4 agouti young. The father of these albinos, it should be said, was an agouti animal.

Agouti animals produced by erossing black with red do not breed true. They produce three classes of young if bred with each other or with ordinary reds. The latter form of test has been more commonly employed in my experiments because I had more red animals than agoutis and it was casier to ascertain their gametic composition. Fourtecn young, however, were obtained from the mating of $F_{1}$ agoutis inter se; they were 2 red, 2 black, and 10 agouti; see table 2, p. 9. The mating with recls produced 111 red, 45 black, and 40 agouti; expected, $98: 49: 49$. This expectation is ealculated as follows: It is expected that half the young will be red because the agouti parent is known to be heterozygous for red. It is also expeeted that half the young will receive the agouti character, which those possessing black pigment will show, but which those possessing only red pigment will not show. Hence all the reds should look alike, but half the others should be agouti. In the mating inter se of agoutis of this generation the expectation is 4 red : 3 black : 9 agouti; the observed numbers, as stated, are $2: 2: 10$, in a slightly smaller total, 14 . The tests summarized above relate to five different $F_{1}$ reversionary agouti males. Three of them were descendants of my original red male, 2054; the other two (9150 and 9152) were sons of Horton's red female. All gave similar results.

Agouti young produeed by the mating already deseribed of an $F_{1}$ reversionary agouti with an ordinary red produced the same kinds of young as did the $F_{1}$ agoutis, viz, red, black, and agouti; see the second division of table 2 . The tests applied in this case were identical in character with those applied to the previous gencration, viz, matings inter se and with ordinary reds (lacking A). Twenty-four different male animals were tested in one or both of these ways, while several females were tested in the first-mentioned way. The data for these are recorded for convenienee in connection with the male involved in the same experiment. Only two of the various animals tested failed to produce all three elasses of young. In the ease of these two, 9602 and 9685 , there can be little doubt that a more extended test would have produced the missing class. Male 9602 produeed 2 black young and 1 agouti. A further test would almost certainly have given red young, sinee his mother was red. Male 9685 produced 4 red young and 2 black ones. That he could also have produced 
agouti young can searcely be questioned. since he was himself an agouti. The total progeny of the 24 males by red females is 133 red, 66 black, and 69 agouti, the expectation being 134:67:67. By agouti mates they produced 25 red, 21 black, and 63 agouti young, the expectation being $27: 21: 61$. These are remarkably close agreements. One of the 24 males, 7932, was also mated with a black female, producing 2 black and 2 agonti young, the expected equality; no red young were to be expected.

Agouti animals produeed by mating agouti animals inter se are not so uniform in behavior as those thus far discussed. Experiment shows that they fall into four groups:

I. Agoutis producing red, black, and agouti young.

II. Agoutis producing only red and agouti young.

III. Agoutis producing only black young and agouti young.

IV. Agoutis producing only agouti young.

Group I is represented by nine agouti males, whose parents were both agoutis; they were enumerated in the third division of table 2 . Together they have produced $(a)$ by red mates, 34 red, 20 black, and 19 agouti young; cxpected $36: 18$ : 18; (b) by agouti mates, 3 red, 5 black, and 14 agouti young; cxpected $5: 4: 12$, if the females were of the same character as the males, as most of them doubtless were: $(c)$ by black mates, 3 black and 3 agouti young, the expected equality, no reds being expected.

Group II is represented by the ten animals enumerated in table 3 . They proved to be incapable of producing black young in any sort of mating. Manifestly they were homogyzous in agouti. By red mates they produced 53 red and 52 agouti young. They were accordingly heterozygous in red, and equality of red and agouti young was to be expected. By agouti mates they produced 13 red and 62 agouti young. The expectation in this case varies with the character of the agouti mate employed, which was not in every case definitely determined. If the agouti mate belongs in Group I or II, then the expectation is 1 red : 3 agouti; but if the mate belongs in Group III or IV, the expectation is all agouti young. If the mates are a mixture of the two sorts, as a random group of $F_{2}$ agoutis should be, then the expectation lies between 75 and 100 per cent agoutis; the percentage obtained is 82.66. By black mates, the Group II agoutis produced 18 young, all agouti, as expected. These were sired by two animals, both of which by red mates had produced red young as well as agouti young.

Group III is represented by the 16 tested animals cnumerated in table 4. They were incapable of producing red young, and hence were homozygous in black. But since they produced black young as well as agouti, it is evident that they were not homozygous in agouti. Three females $(374,437$, and 462) are included only provisionally in this group, since they were not testcd by matings with red animals, but only with black ones. They are known to have produced black young, but it is not certain that they could not also have produced red young, in which case they would fall in Group I. The test in the case of several other animals (as 5, 68, and 314) rests upon too small numbers 
to be conclusive, but suffices to show that the animals in question were not in all respects homozygous, the condition it was desired to obtain in the experiment. These animals were therefore promptly discarded as soon as evidence was obtained that they produced other than agouti young. In the case of animals $191,6197,7894,8020$, and 9939 , the numbers of young are sufficiently large to establish beyond question their position in Group III.

The animals included in table 4 together have produced by red mates 51 black and 91 agouti young. If all the red mates used lacked the agouti factor, we should expect equality of black and agouti young; but from this expectation we observe a considerable divergence. It is quite possible that in some of these tests red animals were used which were descended from $0^{7} 2054$ and had inherited from him an unseen agouti factor, for in making the later tests some such animals were employed, but it is doubtful whether this accounts for the whole discrepancy, amounting to about 14 per cent. This doubt is strengthened by the similar discrepancy observed in the tests with black mates, where we expect equality of black and agouti, but obtain 5 and 12 respectively. The case of animal 191 looks suspicious; he produced only one black young one in a total of 22, yet the record is certainly accurate. We had provisionally pronounced him a pure agouti, when the single black young one came which places him in Group III. It seems doubtful whether the theoretical 50 per cent of his gametes were entirely free from the agouti character. If so, such gametes would seem to have been deficient in vitality. The deviation is, however, not an impossible chance result, though it seems improbable. I regret that this animal was not more extensively tested. The matings of animals of Group III with other agouti animals produced 9 black and 46 agouti young, or 84 per cent agouti, where we expect between 75 and 100 per cent.

Agouti animals of Group IV are included in table 5. They represent the "fully fixed" agouti type breeding exactly like a pure wild species as regards color. Two thoroughly tested animals belong here beyond question, $\sigma^{7} 145$ and $\sigma^{7} 316$; two others less fully tested belong here in all probability, viz, $\sigma^{7} 160$ and $\sigma^{7} 181$, while 9473 is included as a possibly pure animal. She was fully tested qualitatively (by a mating with a brown-eyed yellow animal known to lack both black and agouti), but the number of young obtained is not large enough to make the test conclusive. Similar tests of other females might be included in the table, but they would add nothing to the demonstrative case of $0^{7} 145$, which shows that the reversionary character obtained by crossing can be obtained in a homozygous, pure condition, as it occurs in wild species. The fire animals enumerated in table 5 have produced only agouti young: $(a)$ by red mates, 52; (b) by agouti mates, 125; (c) by black mates, 26.

The occurrence of four different types of $F_{2}$ agoutis indieates that the $F_{1}$ agoutis, their parents, were heterozygous as regards twoindependent mendelian unit-characters, in agreement with the interpretation already given. These two characters are: (1) black-pigmented fur; (2) the agouti pattern (visible only in black-pigmented animals). Designating these two units as $B$ and $A$ respectively, the $F_{1}$ agoutis are all of the formula $A B$ (heterozygous in both 
units). Their gametes are $A B, A, B, O$. If an animal producing such gametes is mated with a red animal lacking both units, the zygotes formed would be, as regards these units, $A B, A, B$, and $O$, or agouti, red, black and red respectively, or collectively 2 reds : 1 black : 1 agouti, as obtained (table 2). Further, such agoutis as came from this cross would be identical in character with the $F_{1}$ agoutis. This expectation is confirmed by table 2 , second division.

But if the $F_{1}$ agoutis are mated inter se, then we expect to get zygotes corresponding with the product of two sets of gametes, each $A B+A+B+O$, that is $A_{2} B_{2}{ }^{*}+2 A_{2} B+2 A B_{2}+4 A B+2 A+2 B+A_{2}+B_{2}+O$. In appearance these zygotes would fall into three classes, agouti, black, and red, as shown in the accompanying table.

The agoutis in this $\left(F_{2}\right)$ generation, it will be noticed, should be of four different types, as actually observed. The $A B$ group should produce all three sorts of young, agouti, black, and red, being heterozygous in both characters, $A$ and $B$. The group designated by $A_{2} B$ would be pure for $A$ but heterozygous for $B$. All their young would be potentially agoutis, but since part of them would lack black pigment, such would be red. Hence they would produce only the two sorts of young, agouti and red; see table 3 . The group designated by $A B_{2}$ would transmit black pigment to all their young, but only part of these would receive $A$. Hence they would

\begin{tabular}{|c|c|c|}
\hline Agouti. & Black. & Red. \\
\hline $\begin{array}{r}4 A B \ldots \\
2 A{ }_{2} B \ldots \\
2 B_{2} \ldots \\
\\
\quad A_{2} B_{2} \ldots\end{array}$ & 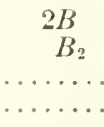 & $\begin{array}{c}2 A \\
A_{3} \\
0 \\
\ldots \ldots\end{array}$ \\
\hline 9 & 3 & 4 \\
\hline
\end{tabular}
produce agouti young and black ones, but no reds; compare table 4.

The group $A_{2} B_{2}$ would transmit both black and agouti to all their young; hence they would produce nothing but agouti young, however mated; compare table 5 . The expected proportions of these four groups of agouti animals are obviously $4: 2: 2: 1$. The numbers shown in the tables are $9: 10: 16: 5$. The apparent deficiency of individuals in Group I and excess in Groups II and III is readily accounted for. Not all the agoutis recorded as derived from an agouti $\times$ agouti cross were second-generation agoutis; many of them were thirdgeneration agoutis, having been obtained from two successive matings of agouti with agouti. In that case one or both of their parents may have been of Groups II or III, in which case the expectation for young of those groups is increased, while that for Group I is correspondingly diminished. Therefore both the kinds of agoutis obtained in the experiment and their numerical proportions are in harmony with the hypothesis presented in this paper.

*The subscript 2 is used (instead of the algebraic exponent 2 ) to indicate double representation of a factor, $i$. e., a homozygous condition as regards it. (See Castle, 1909.) 


\section{SUMMARY.}

1. The agouti coat characteristic of wild eavies and of most other wild rodents is dependent upon the presence in the fur of black pigment disposed in a definite pattern with red (or yellow).

2. The factors which control, respectively, the development of black pigment and the production of the agouti pattern are independent of each other.

3. The agouti coat is obtained only when both these factors are possessed by an individual.

4. Only such agouti individuals as are homozygous in both factors breed true under all eireumstances.

5. An agouti animal which is homozygous in $A$ (the agouti factor), but heterozygous in $B$ (black pigmentation), may produce agouti young and red ones, but not black.

6. An agouti animal which is homozygous in $B$ but heterozygous in $A$ may produce agouti young and black ones, but not red.

7. An agouti animal heterozygous in both $A$ and $B$ may produce three sorts of young, agouti, reol, and black. All $F_{1}$ (reversionary) agoutis produced by crossing black with red are of this sort. Agoutis of the other three sorts are obtained only in the second or later generations of agouti young.

\section{BIBLIOGRAPHY.}

CAstre, W. E., 1905. Heredity of eoat-eharacters in guinea-pigs and rabbits. Carnegie Institution of Washington Publieation No. 23.

-1907 . On a case of reversion induced by eross-breeding and its fixation. Seience, N. S., vol. 25 , p. 1 isl.

-1907a. The production and fixation of new breeds. Proc. Am. Breeders' Association, vol. 3 , p. 34 .

TABLE 1.-Differences among red guinea-pigs as regards the transmission of agouti.

\begin{tabular}{|c|c|c|c|c|c|c|c|c|c|c|c|}
\hline & \multicolumn{2}{|c|}{$\begin{array}{l}\text { loung by } \\
\text { red mates. }\end{array}$} & \multicolumn{3}{|c|}{$\begin{array}{l}\text { loung by } \\
\text { heterozygous } \\
\text { black mites. }\end{array}$} & \multicolumn{3}{|c|}{$\begin{array}{l}\text { Young by } \\
\text { homozy gous } \\
\text { black mates. }\end{array}$} & \multicolumn{3}{|c|}{$\begin{array}{c}\text { loung by } \\
\text { agout i mates. }\end{array}$} \\
\hline & $R \quad B$ & $A g$ & $R$ & $B$ & $A g$ & $h$ & $B$ & $A g$ & $R$ & $B$ & $A g$ \\
\hline $\begin{array}{l}\text { I. Homozygous in } 1 . \\
\text { q Ilorton's red... }\end{array}$ & & & & & & 0 & 0 & 10 & & & \\
\hline 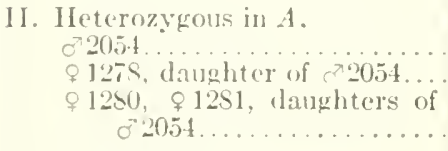 & 10 & 0 & $\begin{array}{r}3 \\
2 \\
10\end{array}$ & $\begin{array}{l}1 \\
0 \\
j\end{array}$ & $\begin{array}{l}2 \\
1 \\
6\end{array}$ & 0 & 3 & 1 & 0 & 1 & 9 \\
\hline 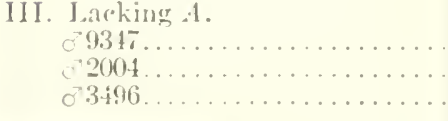 & $\begin{array}{c}44 \quad 0 \\
\ldots \ldots\end{array}$ & 0 & $\begin{array}{l}18 \\
20 \\
19\end{array}$ & $\begin{array}{l}S \\
12 \\
17\end{array}$ & $\begin{array}{l}0 \\
0 \\
0\end{array}$ & & & & & & \\
\hline
\end{tabular}


TABLE 2.-Agouti parents producin! red young, black young, and agouli young.

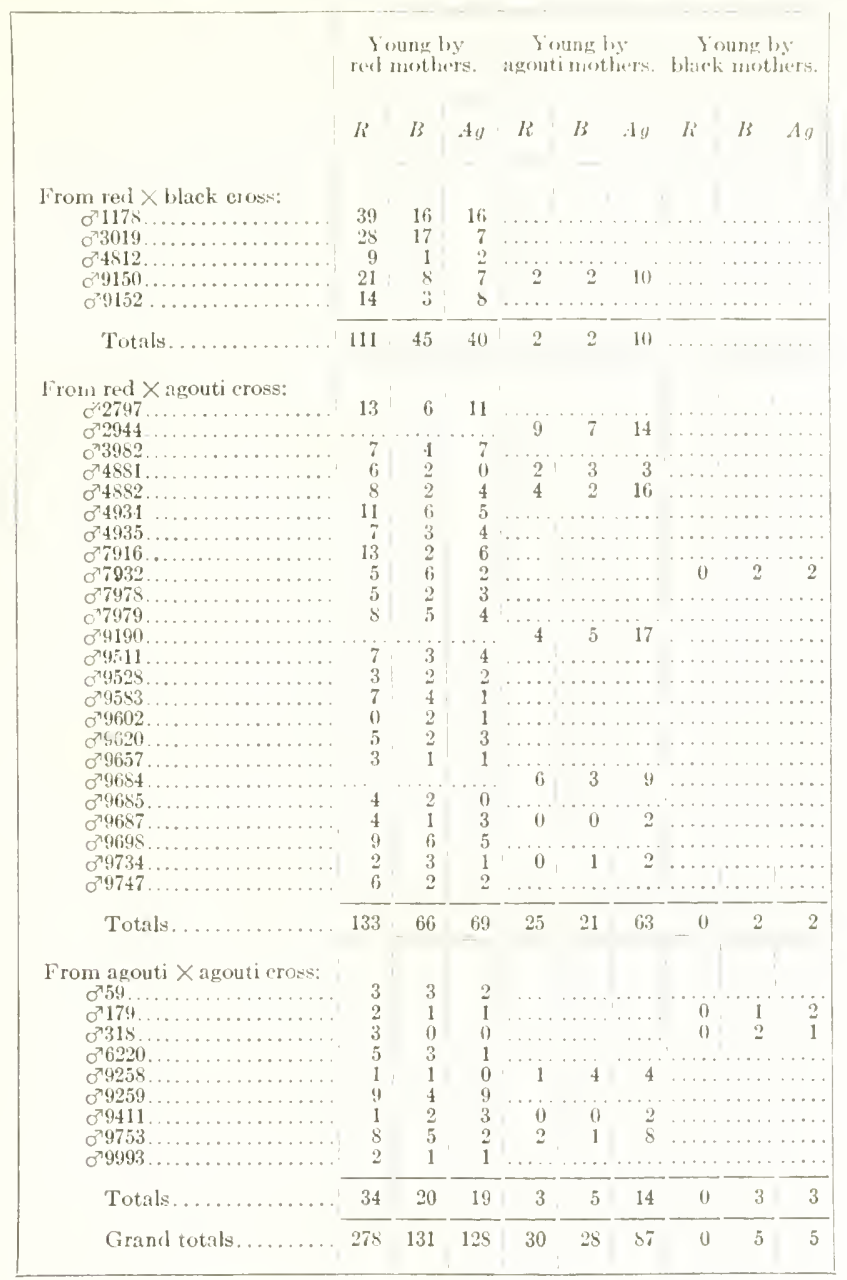

TABLE 3.- Igouti parents producing only red young and agouti young.

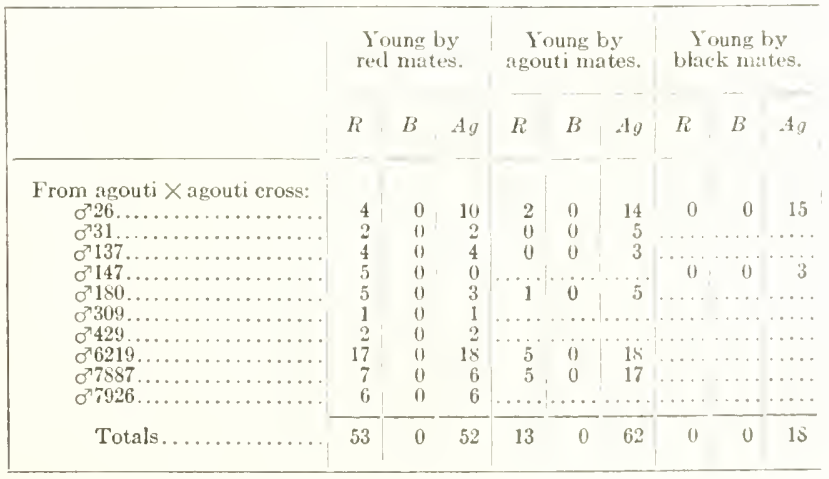


TABLE 4.-Agouti parents producing only black young and agouli young.

\begin{tabular}{|c|c|c|c|c|c|c|c|c|c|}
\hline & \multicolumn{3}{|c|}{$\begin{array}{l}\text { Young by } \\
\text { red mates. }\end{array}$} & \multicolumn{3}{|c|}{$\begin{array}{l}\text { Young by } \\
\text { agouti mates. }\end{array}$} & \multicolumn{3}{|c|}{$\begin{array}{l}\text { Young by } \\
\text { blaek mates. }\end{array}$} \\
\hline & $R$ & $B$ & $A g$ & $R$ & $B$ & $A g$ & $R$ & $B$ & Ag \\
\hline 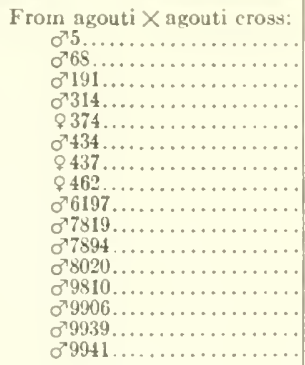 & $\begin{array}{l}0 \\
0 \\
0 \\
0 \\
\cdots \\
0 \\
\cdots \\
\cdots \\
0 \\
0 \\
0 \\
0 \\
0 \\
0 \\
0 \\
0\end{array}$ & $\begin{array}{r}1 \\
1 \\
0 \\
2 \\
\cdots \\
2 \\
\cdots \\
17 \\
5 \\
2 \\
9 \\
2 \\
4 \\
5 \\
1\end{array}$ & $\begin{array}{r}3 \\
4 \\
14 \\
2 \\
3 \\
4 \\
\cdots \\
16 \\
11 \\
2 \\
7 \\
4 \\
6 \\
16 \\
2\end{array}$ & $\begin{array}{l}0 \\
0 \\
0\end{array}$ & $\begin{array}{c}6 \\
0 \\
3 \\
0 \\
0 \\
0 \\
0\end{array}$ & $\begin{array}{r}1 i \\
1 \\
17 \\
\cdots \\
7 \\
3 \\
3\end{array}$ & $\begin{array}{l}0 \\
0 \\
0 \\
\cdots \\
\cdots \\
\cdots \\
0 \\
0\end{array}$ & $\begin{array}{l}0 \\
1 \\
1\end{array}$ & $\begin{array}{l}\cdots \\
\cdots \\
\cdots \\
0 \\
\cdots \\
2 \\
1 \\
\cdots \\
\cdots \\
\cdots \\
\cdots \\
\cdots \\
3 \\
1 \\
\cdots\end{array}$ \\
\hline 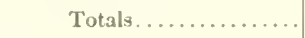 & 0 & 51 & 91 & 0 & 9 & 46 & 0 & 5 & 12 \\
\hline
\end{tabular}

TABLE 5.-Agouli parcnts producing only agouti young.

\begin{tabular}{|c|c|c|c|c|c|c|c|c|c|}
\hline & \multicolumn{3}{|c|}{$\begin{array}{l}\text { Young by } \\
\text { red mates. }\end{array}$} & \multicolumn{3}{|c|}{$\begin{array}{c}\text { Young by } \\
\text { agouti mates. }\end{array}$} & \multicolumn{3}{|c|}{$\begin{array}{l}\text { Young by } \\
\text { blaek mates. }\end{array}$} \\
\hline & $R$ & $B$ & $A g$ & $R$ & $B$ & $A g$ & $R$ & $B$ & Ag \\
\hline 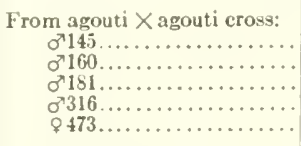 & $\begin{array}{l}0 \\
0 \\
0 \\
0 \\
0\end{array}$ & $\begin{array}{l}0 \\
0 \\
0 \\
0 \\
0\end{array}$ & $\begin{array}{r}21 \\
6 \\
8 \\
14 \\
3\end{array}$ & $\begin{array}{l}0 \\
0 \\
0 \\
0\end{array}$ & $\begin{array}{l}0 \\
0 \\
0 \\
0\end{array}$ & $\begin{array}{r}68 \\
\mathbf{4} \\
6 \\
57\end{array}$ & $\begin{array}{c}0 \\
\cdots \\
0\end{array}$ & $\begin{array}{c}0 \\
\cdots \\
0\end{array}$ & $\begin{array}{l}16 \\
\ldots \\
10\end{array}$ \\
\hline Totals...... & 0 & 0 & 52 & 0 & 0 & 135 & 0 & 0 & 26 \\
\hline
\end{tabular}




\title{
EXPERIMENTAL STUDIES OF THE INHERITANCE OF COLOR IN MICE.
}

\author{
By C. C. LITTLE,
}

Research Assistant in Genetics in the Bussey Institution of Harvard University.

Paper No. 19, Station for Experimental Evolution at Cold Spring Harbor, New York. 


\section{PREFATORY NOTE.}

The experiments on which the following paper is based were begun in the Zoological Laboratory of Harvard University at Cambridge, Massachusetts, in November 1907. Since that time more than 10,500 young have been recorded. In 1909 the animals were moved to the Laboratory of Geneties at the Bussey Institution, Forest Mills, Massachusetts, at which place the experiments are still in progress.

Throughout the course of the experiments the writer has been encouraged, aided, and advised by Dr. William E. Castle, to whom any merit that this paper may possess is chicfly lue.

The skillful and accurate representations of the various eolor varieties are from water-color paintings from life, by $\mathrm{MI}$. Eugene $\mathrm{N}$. Fiseher, whose interest has shown itself in the excellent work that he has done.

The experiments have been supported in part by an annual grant from the Carnegie Institution of Washington made to Dr. Castle "for the continuation of the study of heredity in small mammals."

Charence C. Little.

MAY 1912. 


\section{CONTENTS.}

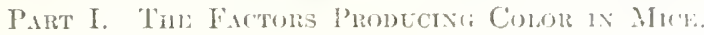

Formative and distributive rolor factors. . . . . . . . . . . .

Location of pigment...... $\ldots \ldots \ldots \ldots$

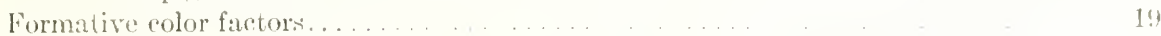

1. The general color fatetor, 1 . . . . .

2. The brown-producing color factor, $B r \ldots \ldots \ldots \ldots$

3. The black-producing eolor factor, $B \ldots \ldots . \ldots \ldots$

Distributive color factors. . . . . . . . . . . . . . 2.

4. The distributive factor, $D \ldots \ldots \ldots \ldots \ldots$

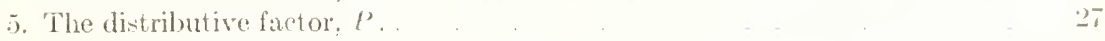

6. The distributive factor, $1 \ldots \ldots \ldots \ldots \ldots$

7. The distributive fartor, $R \ldots \ldots \ldots$.

8. Sooty yellows and sible:......

The inheritance of spotting...... . . . . .

Crosses with Japanese waltzingr nice. . . . 43

Association of churacters...........

Part II. Lxperimestil Dita.

Explanation of symbols. . . . . . . . . .

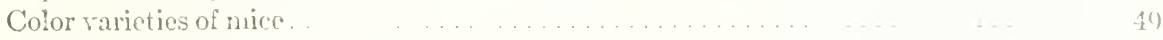

Extexded SERtis. . . . . . . . . . . . .

I. Bluck ayouti (fig. 1) . . . . . . . . . . . . . 50

Black agouti $\times$ black agouti. . . . . . . . . . . . 50

Blark agouti $\times$ dilute black agouti..................

Black agouti $\times$ brown agouti. .............

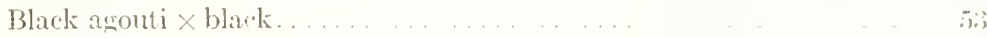

Black agouti $\times$ brown . . . . . . . . . . . . . . . . . .

Black agouti $x$ lilute brown. . . . . . . . . . . .

Black agouti $\times$ pink-eyed brown ..................

Black agouti $\times$ pink-eyed dilute brown. . . . . . . it

II. Dilute black agouti (fig. 2) ...............

Dilute black agouti $\times$ dilute blatck agouti. . int

Dilute black agouti $\times$ black............... n n . n

Dilute black agouti $\times$ pink-eyed black........ . . . . . . .

Dilnte black agouti $\times$ pink-eyed dilute black... . . . o. is

Dilute black agouti $\times$ pink-eyed black agouti...... . . 5

Dilute black agouti $\times$ pink-eyed dilute black agouti....... is

Dilate black agouti $\times$ brown................... is

Dilute bl:cek agouti $\times$ pink-eyed dilute brown . . . . . . is

III. Pink-eyed black agouti (fig. 3) ................... in

Pink-eyed black agouti $\times$ pink-eyed black aqouti. . . . . . . .

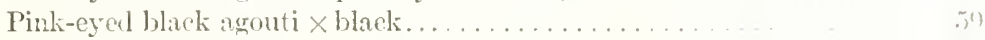

Pink-eyed black agouti $\times$ pink-eyed black. .............. (in)

Pink-eyed black agouti $\times$ dilute black.............. (is)

Pink-eyed black agouti $\times$ dilute brown agouti......... (151)

Pink-eyed black agouti $\times$ brown................ (i) 
ExteNded SERHes-Continued.

IV. l'int-ryed dilute black agouti (fig. 4) ...

V. Broun agonti (fig. 5).

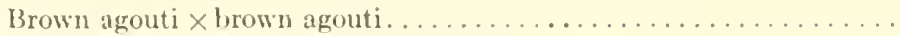

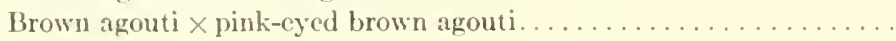

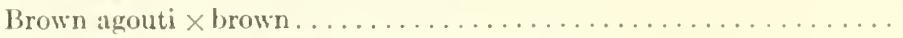

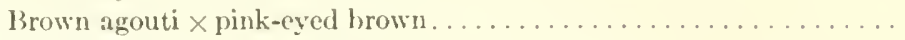

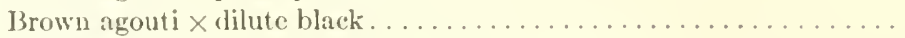

Brown agouti $\times$ pink-eyed dilute brown $\ldots \ldots \ldots \ldots \ldots \ldots \ldots \ldots$

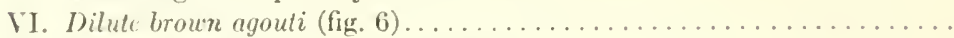

Dilute brown agouti $\times$ pinkeyed dilute brown agouti. . . . . . . .

Dilute brown agouti $\times$ brown . . . . . . . . . . . . . . . .

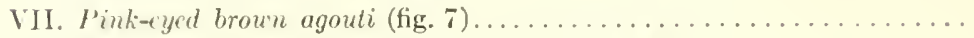

I'ink-eyed brown agouti $\times$ pink-eyed brown agouti.............

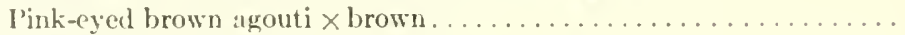

VIII. Pink-tycd dilute brown agouti (fig. S) . . . . . . . . . . . . . . 66

Pink-eyed dilute brown agouti $\times$ pink-eyed dilute brown agouti..... 66

Pink-eyed dilute brown agonti $\times$ dilute brown $\ldots \ldots \ldots \ldots \ldots \ldots . \ldots 6$

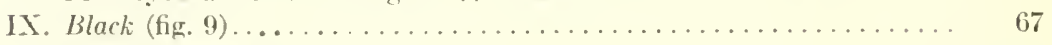

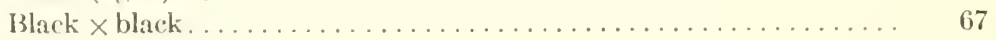

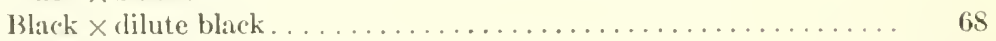

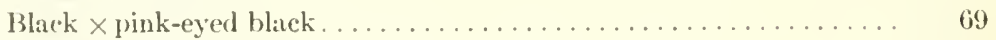

Black $\times$ brown . . . . . . . . . . . . . . . . . . . . . . . 69

Black $\times$ pink-eyed brown . . . . . . . . . . . . . . . . . . 70

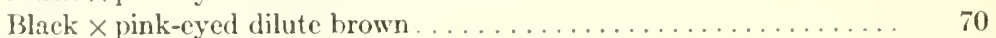

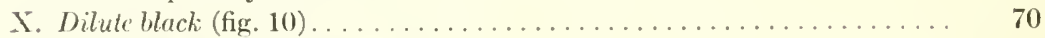

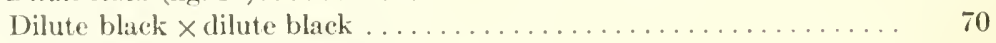

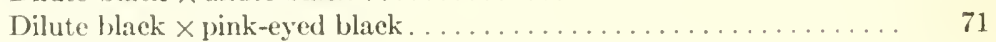

Dilute black $\times$ brown. . . . . . . . . . . . . . . . . . . 71

Dilute black $\times$ pink-cyed brown. . . . . . . . . . . . . . . 72

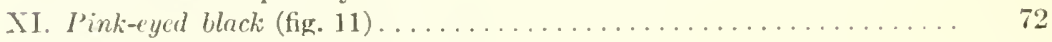

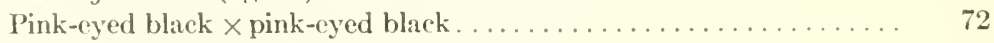

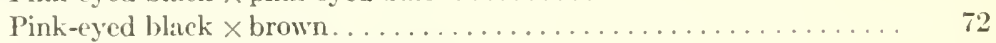

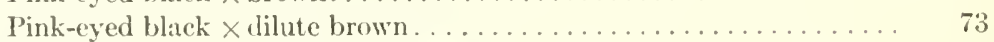

Pink-eyed black $\times$ pink-eyed brown . .................... 74

XII. Pink-eyed dilute black (fig. 12)....................... 74

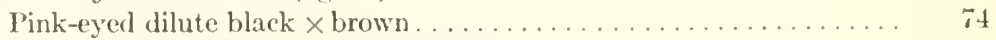

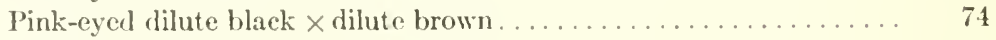

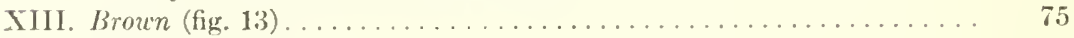

Brown $\times$ brown . ................................... 75

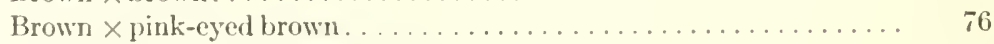

Brown $\times$ pink-eyed dilute brown $\ldots \ldots \ldots \ldots \ldots \ldots \ldots \ldots \ldots \ldots \ldots \ldots \ldots \ldots \ldots \ldots$

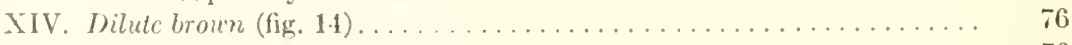

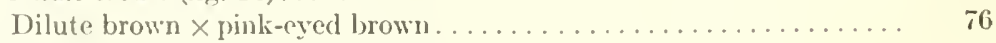

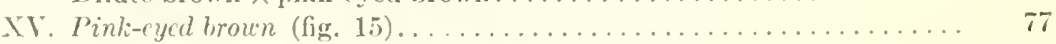

Pink-eyed brown $\times$ pink-eyed brown . . . . . .

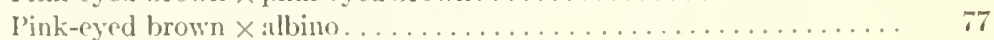

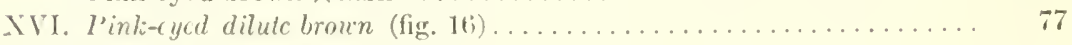

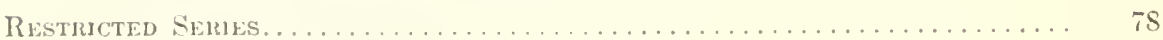

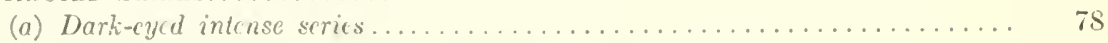

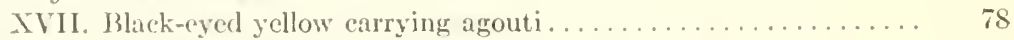

XVIII. I3lack-ryed yellow without agouti (fig. 17) ............. is

XIX. Brown-eyed yellow carrying agouti................ is

$\mathrm{XX}$. Brown-eyed yellow without agouti (fig. 18) ............ is 
Res'Tricted s'erues-Continuel.

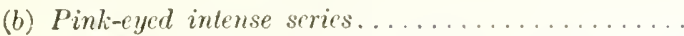

Page

7

7

$7 x$

7

7)

7

$7 x$

$7 x$

$7 x$

in

i)

7

ix

78

i)

so

it

si

8.

53

8.3

8. Sooty yeilow $x$ yellow, giving intense dark-eyed and intense pink-eyed young.

Yellow $\times$ yellow, giving intense and dilute, dark-eyed and pink-eyed young . . . . . . . . . . . . . . . . . . . . . .

Yellow $\times$ yellow, miscellaneous.

Yellow $\times$ dilute yellow, griving only intense dark-cyed young.

Yollow $\times$ dilute yellow, giving intense and dilute dark-eyed young

Fellow $x$ dilute yellow, giving only intense lark-eyed and pink-eyed young...

Fellow $x$ dilute yellow, giving intense and lilute lark-eyed and pinkeyed younir. .

Yellow $\times$ dilutesooty yellow. giving intense and dilute dark-eyer young

I dlow $x$ pink-eyerl yellow, giving only intense dark-eyed young. . .

Yellow $\times$ pink-eyed scllow, giving intense and dilute dark-eyed young .

Yellow $\times$ pink-eyed yellow, giving intense pink-eyed and dark-eyed young.

Yellow $\times$ pink-eyed yellow, giving intense and dilute dark-eyed and pink-eyed young

Cream $x$ vink-eyed yellow, giving only dark-eyed intense youner a

Yellow $\times$ black agouti, giving only dark-eyed intense yound.............

Ycllow $\times$ black agouti, giving intense and dilute dark-eyed young. ... Iellow $\times$ black agouti, giving intense and tilute lark-eyed and pinkeyed young. . . . . . . . . . . . . . . . . . . . . .

Cream $\times$ black agouti, giving only intense dark-eyed young.

Yellow $\times$ dilute black agouti, giving only intense rlark-eyerl young

Yellow $\times$ dilute black agout $i$, giving intense and dilute flark-eyed young

Cream $\times$ dilute black agouti, giving intense and dilute dark-cyed young

Sooty yellow $x$ dilute black agouti, griving intense lark-eyed and pink-

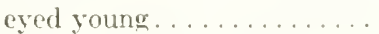

Yellow $x$ pink-eyed black agouti, giving only intense dark-eyed young.

Yellow $\times$ pink-eyed black agouti, giving interse and dilute dark-eyed young..

5

.

;

,

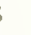

;


Restricted Series-Continued.

(d) Pink-eycd dilute scries-Continued.

Page.

Yellow $\times$ pink-eyed black agouti, giving intense and dilute, dark-eyed

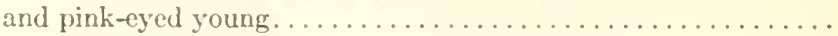

Yellow $\times$ black, giving only intense dark-eyed young. ..........

Yellow $\times$ black, giving intense and dilute dark-eyed young........

Yellow $\times$ black, giving intense dark-eyed and pink-eyed young. ......

Cream $\times$ black, giving only intense dark-eyed young. . . . . . . . . .

Cream $\times$ dilute black, giving only intense dark-eyed young. . . . . .

Yellow $\times$ dilute black, giving intense and dilute dark-eyed young....

Yellow $\times$ pink-eyed black, giving only intense dark-eyed young.....

Yellow $\times$ pink-eyed black, giving intense dark-eyed and pink-eyed young. . . . . . . . . . . . . . . . . . . . . .

Cream $\times$ pink-eyed black, giving only intense dark-eyed young. . . . .

Yellow $\times$ brown agouti, giving only intense dark-eyed young.......

Yellow $\times$ brown agouti, giving intense and dilute dark-eyed young...

Dilute yellow $\times$ dilute yellow, giving only dilute dark-eyed young... .

Dilute yellow $\times$ pink-eyed yellow, giving intense and dilute dark-eyed

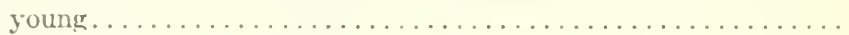

Dilute yellow $\times$ pink-eyed yellow, giving intense and dilute dark-eyed

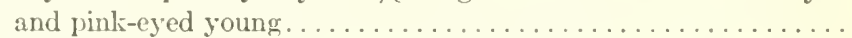

Dilute yellow $\times$ pink-eyed dilute yellow, giving only dilute dark-eyed

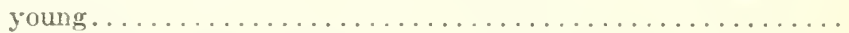

Dilute yellow $\times$ wild black agouti, giving intense dark-eyed young...

Dilute yellow $\times$ dilute black agouti, giving dilute dark-eyed young. .

Dilute yellow $\times$ dilute brown agouti, giving only dilute dark-eyed young

Dilute sooty yellow $\times$ dilute brown agouti, giving dilute dark-eyed and

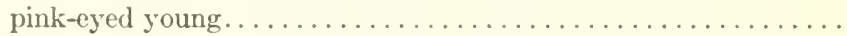

Pink-eyed yellow $\times$ pink-eyed yellow, giving only intense pink-eyed

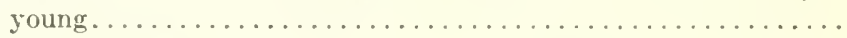

Pink-eyed yellow $\times$ pink-eyed yellow, giving intense and dilute pink-

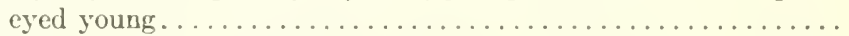

Pink-eyed yellow $\times$ pink-eyed dilute yellow, giving intense and dilute

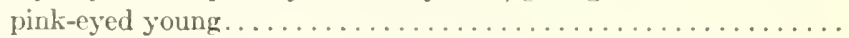

Pink-eyed yellow $\times$ black agouti, giving intense dark-eyed and pink-

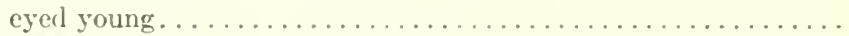

Pink-eyed yellow $\times$ dilute black, giving intense and dilute dark-eyed

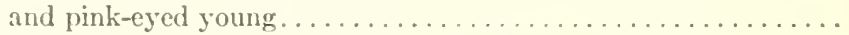

Pink-eyed yellow $\times$ brown, giving intense dark-eyed young.......

Pink-eyed yellow $\times$ pink-eyed blaek agouti, giving only intense pink-

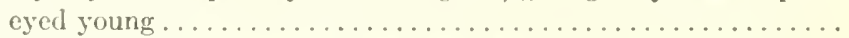

Pink-eyed yellow $\times$ pink-eyed brown agouti, giving only intense pink-

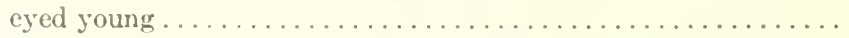

Pink-eyed yellow $\times$ pink-eyed black, giving only intense pink-eyed young

Pink-eyed dilute yellow $\times$ dilute blaek agouti, giving dilute dark-eyed

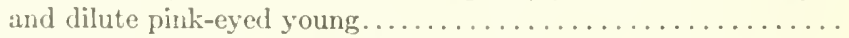

Piuk-cyed dilute yellow $\times$ black, giving intense and dilute, dark-eyed

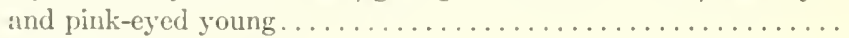

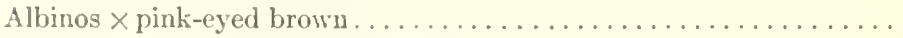

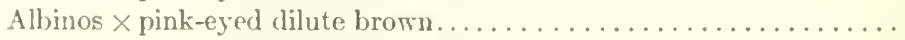

Bibliography

91

91

92

92

92

92

92

93

93

94

95

95

9 รั

96

96

96

96

97

98

98

98

98

98

99

99

99

100

100

101 


\title{
EXPERIMENTA STUDIES OF THE THERITANE OF COLOR IS IIICE.
}

\author{
PART 1. \\ THE FACTORS PRODUCING COLOR IN MICE.
}

In the coat of the common house mouse (Mus musculus) three pigments are recognizable, yellow, brown, and black. No connecting intergradations of color between these three types are visible. The inheritance of these colors and of their distribution, both qualitatively and quantitatively, has been the object of many investigations and is the principal feature of the present paper.

All mammalian color has been found due to melanin pigment. Riddle (1909) has diseussed the process of the formation of melanin pigment and states that all chemical evidence supports the idea that melanin pigment is the product of an oxidation process. The substances (chromogens) on which the oxidizing agents (enzymes) act were found to be tyrosin and certain related aromatic compounds. It has been further shown that tyrosinase-like ferments, which occur widely distributed in the organism, act as oxidizing agents, thus producing melanin compounds. Furthermore, it has been proved that at least artificial melanins may pass through a series of colors before arriving at the final stage of oxidation. In such series the earlier stages of oxidation give lighter colors than the later ones.

Cuénot (1903) advanced an hypothesis to explain the formation of color by the interaction of a chromogen substance and an enzyme. He called the chromogen the general faetor for the production of color, $C$, and supposed that in albinos this chromogen substance is lacking, thus making it impossible for color to be formed. Riddle, however, states that the nature of the chromogen, it being very widely distributed throughout the organism, is such that any theory postulating the absence of this substance would be chemically absurd. Gortner (1912), however, finds evidence that chromogens in insects may be of restricted distribution, thus forming color patterns.

At present it is impossible to decide finally between the explanation offered by Cuénot and that suggested by Riddle. We shall have to await further chemical evidence to determine whether the albino does or does not lack the oxidizable substance or substances necessary for pigment production.*

If we assume that there is only one enzyme present to act as an oxidizing agent, we must assume for it as many different degrees of activity as are required to explain the occurrence of the various colors known to mendelize (three in mice, yellow, brown, and black). If we assume that a different enzyme or

*A recent paper by Keeble and Armstrong (1912) has shown that in Primula sincnsis lack of chromogen scems to be the cause of albinism, thus favoring the original hypothesis of Cuénot. 
group of enzymes is responsible for the production of ach pigment we must suppose that in mice at least three such enzymes or groups of enzymes exist. To determine which of these conditions oceurs in mice is not a problem for the biologist, but for the chemist. The biologist must confine his attention to determining the number of distinct agencies at work in pigment formation irrespective of their chemical nature. These agencies, because of their physiologieal behavior, the biologist chooses to eall "factors," and attempts to learn what he can about their functions in the evolution of color varieties.

\section{FORMATIVE AND DISTRIBUTIVE COLOR FACTORS.}

As has alrealy been stated, three pigments (yellow, brown, and black) are observable in mice. Yellow has been found, by Riddle, to be the lowest in the scale of mammalian pigments. Nevertheless, in mice no rase has been recorded where yellow alone is present. The eye always has, in addition, brown or black pigment granules, while in many cases both are present. The same fact holds good for the coat, so far as observation goes.

These three pigments-yellow, brown, and black-are, however, discontinuous stages. If they are not the products of distinct enzymes they are the result of distinct yrades of activity of a single enzyme. Which of these conditions holds makes no difference at present, so we may, for purposes of discussion, refer their causation to three distinct factors, $\mathrm{Y}$ for yellow, $\mathrm{Br}$ for brown, and b for black.

Certain animals possess yellow and brown pigment to the exclusion of black. In such animals, with no evidenee of variation in the total amount of pigmentation, there oceur varieties in which the proportion of brown to yellow in the coat varies greatly. As the brown increases in amount the yellow decreases. It is fair, then, to assume that something is acting to convert the lower-grade pigment (yellow) into the higher grade (brown). This, we suppose, is the factor $\mathrm{Br}$ already mentioned.

The activity of such a factor may, however, be affected by other factors which determine the amount of brown formed and its location. Experiment shows that these assumed factors governing the development of brown are independent of the brown-forming factor $B r$, for they ean be transferred without visible alteration to animals with black, and vice versa. Such factors we may eall distributive.

Black is the highest grade of mammalian pigment and doubtless, as Riddle states, is a higher oxidation stage of brown; for brown pigment is often, if not always, seen in black animals, but never the reverse. We may, therefore, assume a distinet ageney for the conversion of brown into black and eall this factor $B$. If by a given cross this factor $B$ is added to a certain distributional stage of brown, the corresponding distributional stage of black is obtained, showing that the factor $B$ is independent of the distributive factors.

Such factors as $Y, B r$, and $B$, indieating as they do distinet qualitative steps in pigment formation, we may eall formative factors, in somewhat the same way as the factors controlling the clistribution and amount of pigment have been considered distributive factors. 


\section{LOCATION OF PIGMENT.}

In wild mammals all three pigments (ycllow, brown, and black) commonly oecur in the same hair. In many domesticated or "fancy" varieties, one or the other pigment prevails almost, if not quite, to the exclusion of the others; thus yellow, brown, and black varieties arise. Brown varieties (completely lacking black) oceur in certain mammals (e.g., mice, rabbits, guinea-pigs, and dogs). Theoretically they would seem to be possible in all.

Pigment appears in mice in three general regions. These are the eyes, the skin, and the hair. The pigment occurs in granules.

In the eyes microscopic examination has shown that the pigment granules are located in both the retina and the iris. Of these two localities the iris seems the more permanent pigment-producing center; for when reduction in the amount of pigment oceurs the retina seems the more easily and extensively affected.

In the skin the pigment is located only a short distance from the surface in the malpighian layer. In contradistinction to the eyes, which are visibly pigmented at birth, the skin apparently becomes pigmented only after the animal is several days old; this is largely because the hairs, in which much of the pigment lies, are not formed at birth. The pigment granules of the hair may be clearly observed under the microscope. Bateson (1903), among other investigators, has determined their location with considerable accuracy and finds that they are situated in the cortex or outer sheath of the hair, and also in the interior of the hair in the proximal walls of the medullary spaces.

To recapitulate, we find three general pigment-producing regions in mice: the eye, the skin, and the hair. The pigments (melanins) produced are limited to three: yellow, brown, and black - which we consider to be caused by the action (jointly or severally) of the factors $Y, B r$, and $B$. Domesticated or "fancy" varieties of mice appear to differ from the wild in the partial or complete exclusion of one or more of the pigments. Such exclusion may be the result of (1) the action of a distributive factor, or (2) the loss of the formative factor necessary to the production of a particular pigment.

\section{FORMATIVE COLOR FACTORS.}

\section{The General Color Factor, $Y$.}

It has long been recognized by investigators that, in mice, pigmented varieties differ from albinos by a single mendelian unit-character. Thus in crosses between homozygous self-pigmented and albino animals we find that the first generation $\left(F_{1}\right)$ consists entirely of pigmented animals. If these first-generation hybrids be then crossed inter se we should expect in $F_{2}$ that the ratio 3 pigmented young to 1 albino would be approximated. The experimental results agree well with this expectation and we have as a result of crossing $F_{1}$ inter se:

\begin{tabular}{|c|c|c|}
\hline & Pigmented. & Albino. \\
\hline Observed. & 595 & 206 \\
Expected. & 603 & 201 \\
\hline
\end{tabular}


If we consider, in addition to the above result, those obtained in a similar cross by other investigators, we may construct the following table:

\begin{tabular}{|c|c|c|}
\hline & Pigmented. & Albino. \\
\hline Allen. . . . . . . . & 210 & 97 \\
\hline Cranne . . . . . . . . & 161 & $5 \overline{1}$ \\
\hline Cusmot .............. & 269 & 93 \\
\hline Darbishire........... & 418 & $13 \pi$ \\
\hline Durhan,..... & $80 x$ & 255 \\
\hline Yon Guaita........ & 232 & $i$ \\
\hline $\begin{array}{l}\text { Parsons-Copmuan*. } \\
\text { little.............. }\end{array}$ & $\begin{array}{r}49 \\
595\end{array}$ & $\begin{array}{r}14 \\
206\end{array}$ \\
\hline $\begin{array}{l}\text { Total observed. } \\
\text { Expected!....... }\end{array}$ & $\begin{array}{l}2,788 \\
2,785.5\end{array}$ & $\begin{array}{l}936 \\
928.5\end{array}$ \\
\hline
\end{tabular}

In the eross between the heterozygous pigmented animals obtained in $F_{1}$ and pure albinos, where equality of pigmented and albino young is expected, the following result has been obtained:

\begin{tabular}{|c|c|c|}
\hline & Pigmented. & Albino. \\
\hline $\begin{array}{l}\text { Observed. } \\
\text { Expected }\end{array}$ & 21 & 16 \\
\hline
\end{tabular}

As this cross has been largely negleeted in my experiments the numbers are extremely small. If, however, a table is made showing the work of other investigators, larger and more valuable results are obtained:

\begin{tabular}{|c|c|c|}
\hline & Pigmented. & Albino. \\
\hline 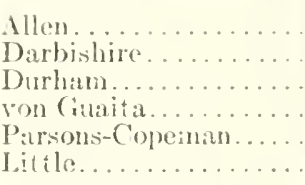 & $\begin{array}{r}84 \\
106 \\
31 \\
24 \\
59 \\
21\end{array}$ & $\begin{array}{r}64 \\
119 \\
33 \\
20 \\
59 \\
11\end{array}$ \\
\hline $\begin{array}{l}\text { Total observed.. } \\
\text { Cxpected........ }\end{array}$ & $\begin{array}{l}325 \\
315\end{array}$ & $\begin{array}{l}311 \\
315\end{array}$ \\
\hline
\end{tabular}

All investigators have found that when albino mice are crossed inter se, only albino young are produced. Albinism is, then, a recessive character. Cuenot (1903) considered albinism due to the loss of the general color factor $C$ (chromogen), but for the reasons given by Ridalle this interpretation seems of doubtful valielity.

As before stated, mammalian pigment results from the action of an enzyme ol chzymes upon a chromogen substance. Albinos are formed from colored varieties by the loss or lestriction of one of these substances. Present chemieal evidence discredits the possible loss of the chromogen; the enzyme or enzymes remain to be consiclered. Albinos probably lack one or more of these. If 
further chemical investigation shoukl show that what albinos laxk is really chromogen, as Cuénot supposed, no change in the gametie formula here used will be necessary, beyond the addition of a symbol $C$ (chromogen) in the case of colored animals.

In the writer's opinion the only enzyme which all albinos in common lack is that which acting alone produces the lowest grade of melanin pignent, namely, yellow. To this supposed factor I have given the designation $Y$. 'The factor' $B$ may or may not be present in an albino, but $B r$ apparently is never lost. $Y$ then forms the step between color and no color, producing yellow when present, no color being produced in its absence. 'This yellow is converted to brown pigment by the ever-present factor $\mathrm{Br}$, whose action, however, is locally inhibited wherever yellow pigment appears as the final oxiclation stage.

\section{The Brown-Producing Color Factor, Br.}

This factor, in my experience, is never wanting, though its presence is often at least partly concealed by the factor $B$, which carries forward the process of pigment formation from the brow to the black stage. In albinos, also, when $Y$ (the factor for producing yellow) is absent the factor Br, lacking the material on which to act, does not function visibly. Thus it is not to be wondered at that this factor $B r$ his been omitted from the zygotic formulæ of most investigators and that brown is considered commonly the result of the absence of black. The chemical evidence already given, however, together with the fact that brown pigment is of ten, if not always, to be found in black animals, seems to justify the use of a distinct term to designate the factor that forms brown. This factor is not to be confused with the absence of the factor for black formation, which is a pure negation and can not be considered as an active agent in the formation of anything.

\section{The Black-Producing Color Factor, $B$.}

As before stated, this factor is necessary for the production of the highest stage of mammalian pigment, viz, black. In its absence, the final oxidation stage is brown, so that we may speak of "animals lacking black" as brown, but it is conceivable that animals might be found which also lack $\mathrm{Br}$, in which case the final oxidation stage would be yellow, not brown, and mere absence of black would not in that case be equivalent to brown.

If we cross, then, animais homozygous for the factor $B$ with animals entirely lacking that factor, we should expect $F_{1}$ to consist entirely of heterozygous black animals. By experiment, 589 animals have been produced in this way, all of which possessed black pigment. We should expect, now, that if such black animals are crossed intei se, the next generation will consist of three animals possessing black pigment to one lacking it completely. When this cross was made the following result was obtained:

\begin{tabular}{|lll|}
\hline & Black. & Brown. \\
\hline Observed ..... & 591 & 216 \\
Exisected ..... & 605.25 & 201.55 \\
\hline
\end{tabular}


In the eross between heterozgous black animals and the extracted brown recessives, where equality of black young and young lacking black are expected, the following result has been obtained:

\begin{tabular}{|l|c|c|}
\hline & Black. & Brown. \\
\cline { 1 - 2 } Observed ..... & 198 & 187 \\
Expected..... & 192.5 & 192.5 \\
\hline
\end{tabular}

If brown animals are crossed inter se, only brown young are expected. The observerl facts coincide with the expectation, $\$ 22$ brown young having been thus obtained.

It is, then, clar that the presence of the factor for the production of black pigment and its absence result in a pair of allelomorphic unit characters. In all the cases above mentioned the heterozygous black animals were indistinguishable from the homozygous blacks, so far as external appearances go. The dominance of black is thus apparently complete. Miss Durham (1911), however, has recorded the occurrence of a distinct heterozygous form ("chocolate lilac") in erosses between pink-eyed black ("blue lilac") and pink-eyed brown ("champagne") mice. The writer has made similar crosses with animals of these color varieties, but is unable to confirm Miss Durham's results.

Pink-eyed black mice vary in depth and intensity of pigmentation, which fact will be discussed more fully under the head of distributive factors, but the writer has been unable to detect any greater degree of brownness in the pinkeyed blacks which are heterozygous ("chocolate lilaes") than in those which are homozygous. While it is possible that microscopic examination of the hair of such heterozygous pink-eyed black animals may reveal a greater relative amount of brown than occurs in the homozygous form of the same color variety, it seems of doubtful propriety to call the heterozygous form a distinct color variety. Furthermore, if the distinction between homozygous and heterozygous pink-eyed blacks were a good one, it should be recognizable in the heterozygotes produced by crossing pink-eyed black agouti with pink-eyed brown agouti types. Miss Durham, however, mentions no such difference between homozygous and heterozygous pink-eyed black agoutis, and I have been unable to find any such difference in my own experiments.

Black, in its method of inheritance, forms one of the best examples of a mendelian unit character. It is, moreover, clearly a positive character which is dominant over its absenee, or chemically expressed it is a higher oxidation stage epistatic to a lower stage and independent of the latter in inheritance.

\section{DISTRIBUTIVE COLOR FACTORS.}

We have seen that three factors act as agents in the formation of the pigments of mice. We may now consider the factors concerned in controlling the distribution of pigments thus formed. It is obvious that theoretically the distribution of pigment may be controlled in two general ways: (1) by the 
ability to form either a grater or less total anount of pigment; or (2) by the restriction or loss of one or more pigments from eertain portions of the pelage, thus produeing "coat patterns." The existence of two distinct faretors of each of these types has been proved ly experiment. "These will he presently described.

For a basis from which to calculate increase or climimution in the total amount of pigmentation (the first category of morlifieations montioned), it is desirable to have, as a standard, some known stock of as noarly constant pigmentation as possible. For this purpose none seems better than the wilk house-mouse, Hus musculus. There is, to be sure, variation anomg the wild individuals of this species, but on the whole it forms as satisfactory and constant a basis as can be obtained. To the factor produeing the degree of pigmentation observed in the eommon house-mouse we may give the designation $D$ ) (density of pigmentation).

This factor $D$ affeets the distribution of pigment granules of the three sorts, yellow, brown, and black, but there is experimental eviclenee that another factor exists which determines the amount of brown and black granules present withont affecting the number of yellow granules in the coat. To this factor we may give the designation $P$ (plenitude or fulness of brown and black pigmentation). There is a complete series of eolor varieties as deseribed by Castle and the writer (1909), in which simultaneous modifieations of both these factors exist, as well as two other series in each of which one only of the two factors is modified.

Of the second eategory of distributive factors, those which cause local restriction or loss of eertain pigments, there are two clear examples in mice. The first of these is seen in the ease of the wild type, where the so-called "agouti" pattern exists. This pattern results from the activity of a factor determining the order in which pigments are laid down in the individual hair, and also produeing a differentiation between hairs of the dorsal and ventral surfaces. This factor we may designate A (agouti). A factor of this sort produces the "ticked" coat eharaeteristic of almost all wild rodents. In the absence of A, animals are self-colored.*

The second factor of this category is a restrictive factor which almost excludes black and brown pigment from the hair and skin, thus leaving a preponderance of yellow granules in those localities and producing the so-called "yellow" varieties of mice. This factor we may (all $R$ (restriction). In its absence colored animals are either agouti if $A$ is present, or self-colored if $A$ is absent.*

From this very brief deseription it may be seen that the presenee of certain distributive factors, or modifications of them, determines what color varietics of mice shall be formed. These distributive faetors determine either the total amount of pigmentation or the relative amounts of yellow, brown, and black that are visible. It is, then, obvious that they are factors douling with "quantity" of pigment, not with "quality" of pigment, as do the formative facturs $Y, B r$, and $B$. Since the "distributive" factors $D, P, A$, and $R$ deal with

*This ignores spotted forms, which will be considered separately. 
quantity of pigment, we might expect that they would show more fluctuations than do the formative or qualitative factors $Y, B r$, and $B$; and such is the case, as will presently be more fully described.

\section{The Distributive Factor, $D$.}

We have stated that this factor is responsible for the degree of density of yellow, brown, and black pigmentation seen in the common wild house-mouse. The presence of this factor is allelomorphic to a modification of density of pigmentation which we may call "dilute" pigmentation and designate by $d$. This dilute type of pigmentation was recognized by Bateson (1903) in mice. At that time he stated that it consisted of a reduced number of pigment granules, affecting both the cortex and medulla of the hair. To this the writer may add that the pigmentation of the skin is visibly lessened in "dilute" forms, and that the eyes are also affected. When the eye of a "dilute" mouse is examined under the microscope, reduction in the amount of pigment, as compared with the densely pigmented forms, is seen to exist. This reduction oceurs in both retina and iris, but is more extensive in the former locality than in the latter.

The dilute forms of rabbits, as compared with the intense forms, show, on microscopic examination of the hair, a reduction in number of the pigment granules in the cortex of the hair. The dilution in this case seems transferable to hair of any color and is therefore comparable to dilution in mice, as it is also in superficial resemblance, having a streaky and washed-out appearance to the unaided eye.

In guinea-pigs the condition seems somewhat different. The problem there does not appear to have been worked out with especial reference to dilution. There dilute forms do not appear streaky, although the eream type of reduction seems either directly or indirectly transferable to black and brown. It seems, however, doubtful whether a true dilution exists in guinea-pigs. There is no evidence showing a modification of the intense colors, which modification behaves as a unit character; and it seems probable, from the recent occurrence of a pink-eyed colored guinea-pig (Castle, 1912b), that the reduction of pigment seen in guinea-pigs is due to a modifieation approaching that seen in pink-eyed mice, rather than the dilute modification.

The "dilute" modification affects all three pigments (yellow, brown, and black), wherever they may occur. Castle and the writer (1909) recognized this in mice in the "non-yellow" varieties, including those possessing the agouti factor. Plate (1910) recognizes a dilute series of color varieties, though using a slightly different nomenclature to designate them. Morgan (1911a) independently puts on record the oecurrence of dilute animals with the agouti pattern. Miss Durham (1911) also recognizes the existence of a dilute type of every color variety. Previous to that time, however, she had not recognized the relation of the dilute agouti animals to the dilute "non-agouti" forms.

Entirely distinct from this modification of the factor for density of pigmentation, which produces dilute forms, is the fluctuation of the degrec of density itself. Though "density" and "dilution" act as a pair of allelomor- 
phic characters, "density" is subject to considerable fluctuation. Thus we may have a gradual series of yellow mice, all possessing the factor $D$, but varying in depth of pigmentation from an extremely light cream-color to a deep rich orange. Microscopic examination of the hair of these various forms shows in "cream" animals a distinctly smaller amount of pigment than in the hairs of the darker grades of "dilute" yellow animals. Dilute animals also vary in depth of color. For example, certain dilute browns may be of a distinctly lighter color than others. We know from the behavior of "density" and "dilution" in crosses that they are allelomorphic to each other, but we must admit that they are fluctuating characters and not stable in the sense of the formative qualitative factors $Y, B r$, and $B$. The differences in depth of color in the case of any color variety, either intense or dilute, are more casily discerned in those animals which have a preponderance of light pigment, such as yellows, or in those possessing reduction in amount of pigment due to some modification, such as dilute dark-eyed and intense pink-eyed mice.

In this connection it is interesting to note the occurrence of certain "coat patterns" on mice, reported by Morgan (1911a). He describes, among others, patterns consisting of distinct regions of lighter and darker color. He further states that when the iight hairs are examined under the microscope they show a lessening of pigment granules in different regions, "a lessening that is a characteristic feature of the so-called dilute condition." But as reduction in the amount of pigment occurs in the case of the "light" densely pigmented and the "pink-eyed" forms, as well as in the dilute forms, evidences of the sort offered by Morgan can not be considered to establish his conclusion.

Is it not possible that these cases are those of intensely pigmented animals showing on their coat somatic segregation of certain of the fluctuations that are seen in dense pigmentation? Such "lightness" would not be in any way" correlated with ditution, and would appear in homozygous animals as well as in heterozygous ones.

The writer suggested (1911b) that such patterns as were described might not be a criterion of the heterozy gosity of their possessor, but due entirely to the physiological condition of the animal at moulting. Morgan in reply (1911c) stated that the cases he described were not "moulting" patterns, which were, as he stated, "too familiar to *** call for comment." Iet in his first paper (1911a) he mentions certain "gray" animals, and figures two, which, as he states, "show areas of lighter and darker color, and these may come and go at each moult."

The writer has obtained in a homozygous dilute brown animal ( 7317 ) regions of clearly lighter hair than the predominant body color of the individual. These lighter hairs are apparently full-grown, and remained clearly distinguishable in this animal for nearly a year, after which the animal died. If this individual was heterozygous he might, as Morgan states, be considered as giving "evidence of his clual nature," but his gametic composition is "single?" so perhaps the "evidence" in the case of the heterozygous animals reported by Morgan is a matter of coincidence. 
The above-described fluctuations in the density of pigmentation are to a certain extent hereditary. Thus cream-colored mice crossed inter se have a greater number of cream-colored than of deep-yellow young. So, too, from deep-yellows crossed toget her the decp-yellow young preponderate, but creamcolored young may oceur as well.

We may now eonsider the result of crosses between intense animals possessing the factor $D$ and animals with the modified or "dilute" condition $d$. If homozygous intensely pigmented animals $(D D)$ are crossed wtih dilute animals $(d d)$ only intense young $(D d)$ are formed in $F_{1}$. In my experiments 424 young have been thus produced, all intense, manifesting $D$. If these heterozygotes are erossed together we should expeet in $F_{2}$ the ratio 3 intense to 1 dilute young. The experimental results are as follows:

\begin{tabular}{|c|l|c|}
\hline & Intense. & Dilute. \\
\hline Observed ..... & 610 & 205 \\
Expected..... & 605.25 & 203.75 \\
\hline
\end{tabular}

When the heterozygous intense animals are crossed back with the dilute type the following results have been obtained:

\begin{tabular}{|c|c|c|}
\hline & Intense. & Dilute. \\
\hline Observed..... & 301 & 197 \\
Expected..... & 249 & 249 \\
\hline
\end{tabular}

Here there is a marked deficiency of dilute animals, which is in all probability partly due to failure on my part to recognize as dilute certain of the pinkeyed dilute animals produced during the years 1907-08. During these years many matings of this type were made. In classifying the young obtained from these I may have been in error. Thus if we consider the matings made sinee 1908, which should theoretically produce both dilute and intense young, we should have the following results:

\begin{tabular}{|c|c|c|c|c|}
\hline & \multicolumn{2}{|c|}{$\begin{array}{l}\text { Cross of heterozygous } F \\
\text { intense animals inter se. }\end{array}$} & \multicolumn{2}{|c|}{$\begin{array}{c}\text { Cross of heterozygons } F_{i} \\
\text { intense animals with } \\
\text { recessive. }\end{array}$} \\
\hline & Intense. & Dilute. & Intense. & Dilute. \\
\hline $\begin{array}{l}\text { Observed. } \\
\text { Expected. }\end{array}$ & $\begin{array}{l}345 \\
363.7 .5\end{array}$ & $\begin{array}{l}140 \\
121.2 .5\end{array}$ & $\begin{array}{l}146 \\
156\end{array}$ & $\begin{array}{l}166 \\
156\end{array}$ \\
\hline
\end{tabular}

Here there is an excess of dilute animals, which makes it seem probable that in the matings previous to 1909 , of the two types given above, I confused the dilute and intense pink-eyed forms, often failing to distinguish them cor- 
rectly. However, I feel sure that errors of this sort have not occurred since 1909 , and the figures given above may be considered as a correct representation of the observed facts. For the most part the behavior of density and dilution is clearly that of a pair of allelomorphic unit characters, and they may therefore be treated as such. Thus dilute animals crossed inter se give, as expeeted, only' dilute young, 603 such animals having been produced.

\section{The Distributive Factor, $P$.}

As before stated, this factor affects brown and black pigment, lut does not affect the amount of yellow present. The modification of this factor giving rise to the "pink-eyed" series of colored mice, reduces the amount of black and brown pigment to a very great extent. The reduction affects hair, skin, and eyes. Miss Durham (1908) has pointed out the fact that the eyes, as the hair, are not entirely devoid of pigment. In examining with the microscope sections of the cye of a "pink-eyed" colored mouse, she found traces of pigment present, but in such minute quantities as to make any qualitative analysis impossible. The writer has examined under the microscope crushed eyes of the brown, dilute brown, pink-eyed brown, and pink-eyed dilute brown varieties and has thus been able to trace the steps in the reduction of pigment in these four varieties with fair success. The eyes were prepared by dehydrating and clearing in xylol. The lens was then removed and the iris and retina spread on the slide and mounted in balsam. When thus prepared, the following conditions were observed:

(1) In intense-brown animals, the iris is more heavily pigmented than the retina, but both are thickly pigmented with brown only, no yellow.

(2) In dilute-brown animals, there is reduction of the total amount of pigment, but the retina shows the effects of the reduction more than does the iris. The pigment is brown only, no yellow.

(3) In pink-eyed intense-brown animals there is very little pigment in the retina. The iris is moderately pigmented, but much less so than in the dilutebrown form. The pigment is brown only.

(4) In pink-eyed dilute-brown animals the retina is apparently unpigmented, but the iris still contains a small amount of brown pigment. No yellow pigment is present.

We may now turn to the experimental results obtained in crosses between dark-eyed animals $(P P)$ and pink-eyed animals $(p p)$. In this case $F_{1}$ consists entirely of dark-eyed animals $(P p), 1,085$ individuals having been thus obtained, all dark-eyed and to external appearances indistinguishable from homogyzous dark-eyed animals. These $F_{1}$ heterozygotes crossed inter se have given the following result:

\begin{tabular}{|c|c|c|}
\hline & Dark-eyed. & Pink-eyed. \\
\hline Observed.... & 1,673 & 457 \\
Expected.... & $1,597.5$ & 532.5 \\
\hline
\end{tabular}


If these results are alded to those obtained by Miss Durham in similar matings we have:

\begin{tabular}{|c|c|c|}
\hline & Dark-eyed. & P'ink-cyed. \\
\hline $\begin{array}{l}\text { Durbam............. } \\
\text { Little................ }\end{array}$ & $\begin{array}{r}576 \\
1.673\end{array}$ & $\begin{array}{l}303 \\
457\end{array}$ \\
\hline $\begin{array}{l}\text { Total observed.. } \\
\text { Expected....... }\end{array}$ & $\begin{array}{l}2,549 \\
2,481.6\end{array}$ & $\begin{array}{l}760 \\
827.4\end{array}$ \\
\hline
\end{tabular}

The result is not strikingly close to the expeeted numbers. There is in my experiments a deficieney of pink-eyed animals too extensive to be overcome by the excess of pink-eyed obtained by Miss Durham. The difference in result in the two cases may be considered as probably too great to be due entirely to chance.* Furthermore, in the following cross the result is still more aberrant and again there is a lack of pink-eyed animals. The cross is that of heterozygous dark-eyed animals $(P p)$ with pink-eyed animals $(p p)$. Equality of darkeyed and pink-cyed young is expected.

\begin{tabular}{|r|cc|}
\hline & Dark-cyed. & Pink-eyed. \\
Observed... & 370 & 284 \\
Expected... & 327 & 327 \\
\hline
\end{tabular}

Here, if the higher numbers (gained by adding Miss Durham 's results) are considered, the numbers are closer to equality, though still widely unequal:

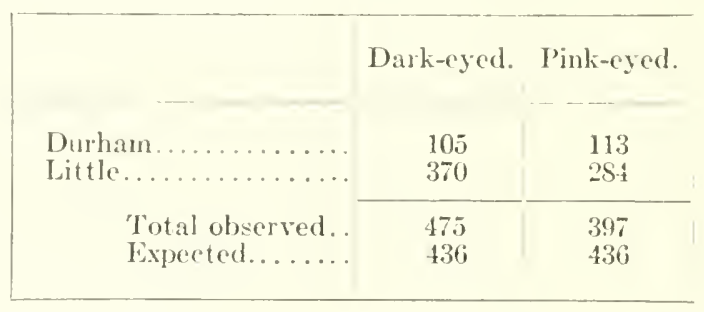

It is possible that in the "pink-eyed" animals of my strain some constitutional weakness exists, either directly connected with the "pink-eyed" modification or to a marked degree correlated with it, which tends to cause a higher degree of mortality among the pink-eyed than among the dark-eyed young. I have tried, so far as possible, to record the eye-color of young at birth, but have failed in many cases. Even if it had been possible, it would not be safe to state that animals with apparently unpigmented eyes were all pink-eyed colored forms, for albinos at birth are indistinguishable from the pink-eyed colored series.

When "pink-eyed colored animals are crossed inter se, only "pink-eyed" animals have been produced; 496 young have been thus obtained.

*Using the method deseribed by East \& Hayes (1911) p.37, we find that the deviation from the expected ratio is 0.0810 , while the probable error is \pm 0.0752 . 
"Pink-eyed" colored varieties are mueh "yellower" in applurance than their corresponding dark-eyed intense and dilute forms. This is due to two facts:

(1) That in such forms as the pink-eyed black agouti and pink-eyed brown agouti (both intense and dilute) the yellow band of the agouti pattern is left fully pigmented, while the black and brown pigment in the same hairs is much reduct in amount. Similarly pink-eyed yellow animals possess fully pigmented yellow hair and thus have as heavily pigmented eoats as do the dark-eyed yellow types.

(2) In the pink-eyed black and pink-eyed brown varieties (intense and dilute) there are no yellow pigment granules in the hair, but the extremely snall amount of black or brown pigment present gives the optical effect of an animal with yellow pigment. This is espeeially marked in the case of the pink-eyed brown variety.

The mutual independence of the factors $D$ and $P$, and of their modifications $d$ and $p$, was recognized by Castle and the writer (1909) and found to hold good in all the color varieties, whether possessing the agouti pattern or not. At that time we reported the cross of a dilute "dark-eyed" animal with an intense "pink-eyed" animal, resulting in the production of a "dark-eyed intense" $F_{1}$. We had then only a small number of $F_{2}$ animals from such crosses, but those showed that the four theoretical elasses of offspring were produced. In similar erosses we have now obtained the following result:

\begin{tabular}{|c|c|c|c|c|}
\hline & $\begin{array}{l}\text { Dark-eyed } \\
\text { intense. }\end{array}$ & $\begin{array}{l}\text { Dark-eyed } \\
\text { dilute. }\end{array}$ & $\begin{array}{l}\text { Pink-eyed } \\
\text { intense. }\end{array}$ & $\begin{array}{c}\text { Pink-cyed } \\
\text { dilute. }\end{array}$ \\
\hline $\begin{array}{l}\text { Ubserved. } \\
\text { Expected. }\end{array}$ & $\frac{71}{77}$ & $\begin{array}{l}32 \\
25.7\end{array}$ & $\frac{25}{2.5} .7$ & 30 \\
\hline
\end{tabular}

Other erosses showing the independence of $D$ and $P$ have been made, and the results all follow the expectations with reasonable accuracy. Miss Durham (1911) has also recognized the independence of $D$ and $P$, but without giving numerical results showing the oceurrence of the intense and dilute types of the various pink-eyed eolor varieties. She, however, recognizes the independence of pink-eye and dilution only in those mice "in which yellow is absent." The fact that their independence has been observed and experimentally proved in animals (agouti) in which yellow is present seems to remove this restriction. 'Thus, for example, the cross reported in 1909, and already referred to, shows that their independence is clear-eut, ever in the individual hair, and that the presence of yellow in the hair aids in showing their independence; for in the dilute agoutis (brown or black) all the pigment in the hair is reduced in amount, while in the pink-eyed agoutis (brown or black), the yellow band in the hair is as heavily pigmented as in dark-eyed agouti forms.

We may now consider, in order, the two factor's which have to do with the relative distribution of the three pigments, yellow, brown, and black, in the hair and skin. These factors $A$ (agouti) and $R$ (restriction), already bricfly deseribed, have certain characteristies in common, and evidence exists (as will 
be discussed later) that they may be closely related. Their sphere of action is limited to the hair and skin, to the exclusion of the eye. In this respect they differ fundamentally from the distributive factors $D$ and $I^{\prime}$, already described.

\section{The Distribetive Factor, $A$.}

This factor was first recognized by Cuénot (1902) uncler the designation of $G$ (gris), as producing the pattern seen on the coat of the wild honse-mouse; but he erred in considering the factor $(i$ as allelomorphic to the factor $N$ (noir) for the production of black pigment. Castle $(1907 a)$ proved that in guinea-pigs. the agouti pattern is a unit character allelomorphic to its absence. Guided by this hypothesis he formed a new color valriety of guinea-pig (cimnamon). Furthermore, he proved $(1907 a)$ that the agouti pattern might be carried by certain red animals, which when erossed with blacks produced agouti young in the first generation. By experimental test it was proved that all black animals behaved the same in the crosses made and that the reds differed. II (1911a) quotes Castle as stating that in the above-mentioned erosses both the blacks and reds were able to transmit the agouti type of coat. Having thus niisquoted ('astle, Morgan offers as a suggestion the explanation which Castle proved was eorrect in 1907 .

The agouti pattern eonsists in mice (Allen, 1901) of two chief types of clorsal hairs: (1) Those haring a fine black tip, a sub-apieal band of light ochraceous color (oceupying about one-fifth of the hair) and a dark plumbeous basal portion. (2) Others, less numerous, are black throughout.

The ventral hairs Allen describes as possessing a distal half, which is dirty white to pale ochraceous buff, and a basal half which is plumbeous. Cantle $(19076)$, in describing the agouti pattern in guinea-pigs, states that the lips are bluck in hairs showing the ticking; then follows a yellow or red band, and then the hair is black to the base. Both of these investigators find that the "tieked" Irairs have black tips, as does Hurst (1905) in the case of rabbits.

Morgan (1911a) states that he has obtained black animals which have certain of their hairs brown-tipped. These he characterizes as agout is without the yellow band and further states that the ticked hairs in the coat of "agouti" animals are brown-tipped. It is obvious that he is dealing with acolor pattern in his "gray" (agouti) animals which is not identical with the agouti pattern as described by other investigators. It tends, therefore, to confusion to treat the pattern that he is dealing with as agouti. Furthermore, it seems probable that the blacks, which he reports as having ticked (brown-tipped) hairs, do not possess a factor in the least comparable with the "agouti" pattern. Morgan himself states that these brown-tipped hairs occur only in heterozygous black mice. The question suggests itself, how can mice possess, as a result or necessary concomitant of heterozygosis, a pattern which is the characteristic of a homozygous wild race?

I3ateson (1903) stated that in black mice the tips of the large contour hairs are often brown. Ticked hairs in non-agouti (black) mice are not, then, a new development, and as black mice have been long used in experiments and have 
never been found to transmit the agouti pattern, it seems that Morgan has been misled by the superficial appearance of "ticking" in the hair.

That superficial ticking is not identical with the agouti pattern is observable in the case of "sable" mice, as will be more fully discussed later. It is also observable in certain "dingy" or "smoky" young produeed by Himalayan rabbits. In this case there may be as many as two light bands in the "ticked" hairs, the dark portions of which seem to contain a small amount of black pigment producing the dingy appearance alluded to. In such cases it is known that neither parent carries the agouti pattern, yet here are hairs with an apparently similar ticking; therefore not all ticking of rodent hairs is due to the same factor.

We may now consider crosses in which the "agouti" pattern is involved. In the cross between homozygous agouti and non-agouti forms, $F_{1}$ consists entirely of agouti (black agouti or brown agouti) animals, 344 young having been thus obtained. When certain of these heterozygous $F_{1}$ animals were crossed inter se there were obtained:

\begin{tabular}{|c|l|l|} 
& Agouti. & Non-agouti. \\
\hline Observed.... & 257 & 74 \\
Expected.... & 243.75 & 81.25 \\
\hline
\end{tabular}

If the heterozygous $F_{1}$ agoutis are crossed with non-agouti mice we should expect equality of agouti and non-agouti young. In this cross I have obtained:

\begin{tabular}{|c|c|c|}
\hline & Agonti. & Non-agouti. \\
\hline Observed.... & 194 & 170 \\
Expected... & 182 & 182 \\
\hline
\end{tabular}

When non-agouti animals are crossed inter se only non-agouti young are produced, the numbers in this case being 1,812 .

From the result of these crosses it may be stated that the agouti pattern, though it may or may not be a single unit character, certainly behaves like one. Until it has been shown to be complex, the only safe course seems to be to consider it simple and allelomorphic to its absence.

\section{The Distributive Factor, $R$.}

This factor produces the true yellow varieties of mice by an almost complete exclusion of brown and black from the skin and hair. In those localities, therefore, the process of pigment formation is carried only as far as the "yellow" stage. The chief point of importance in connection with the appearance of yellow in the coat is this: Ycllow-pigment granules, so far as experimental evidence goes, never appear in the skin and hair of mice unless certain distributive factors ( $A$ or $R$ ) are present to exclude part or all of the brown and black from those localities. In such regions oxidation beyond the yellow stage is impos- 
sible. In the absence of factors $A$ and $R$ the oxidation proceeds, over the whole coat, to the stage determined by the presence of the formative factors, $B r$ or $B$.

"Ycllow" mice are not produced by a factor comparable to the factors $\mathrm{Br}$ and $B$, but by a factor having an entirely different function, namely, that of restriction or inhibition. The nature of the agouti factor $A$ is also restrictive, though in a much more limited degree. Thus the factors $A$ and $R$ have functions which are roughly comparable, in that they both "restrict" the formation of black and brown, allowing yellow to take their place.

In stuelying the relation of "yellow" to black agouti mice, Miss Durham (1911) has obtaincl extremely interesting and valuable results. Thus she has in two eases obtained at "yellow" animal from agouti parents, which is a reversal of the ordinary conditions. The fact that such a reversal of dominance ean exist is of extreme importance and adds one more peculiarity to the genetie behavior of "yellow" mice. In all crosses made by the writer, however, yellow has prover epistatic to black agouti. When the black agouti young olutained from yellows were cossied inter $\varepsilon, 71$ young were obtained, none of which were yellow.

When eream (fig. 18) is erossed with wild black agouti the yellow young obtained are cream; thus 3 eream and 2 light-black agouti young have been obtained. The wild black agouti possesses potentially a "eream" degree of pigmentation. If ereams are crossed with black agouti animals produced by synthesis in experiments with other varieties, the yellow young produced are yellow, not crcum, thus 12 yellow and 6 intense non-yellow young have been produeed. These synthesized agout is, then, are not potentially eream, but are darker-colored members of the series which fluetuates between cream and deep orange.

Cucinot (1905) reported the fact that homozygous yellow mice were not obtainable in his extensive experiments. This fact has been corroborated by other investigators. ('uénot (1911) has stated that the factor R, which restricts brown and black from the pelage, is the same in function as the factor $Y$, which forms the "yellow" degree of oxidation, and that there is no need of including both in the gametic formulx of mice. But chemical evidence indieates that all brown or black pigmented mice must possess the ability to form yellow pigment in order to form the higher stages, viz, browi and black. Furthermore, they must possess this at times in all their gametes, otherwise a homozygous brown or black animal would be impossible. $Y$, therefore, which produces the yellow degree of oxidation is not eomparable to $R$, which ean oceur in only one of the gametes of a zygote and which restricts brown and black forming material, thus producing visibly ycllow mice.

Mice homozygous in $Y$ are represented by wild black agoutis, but mice homozygous in $R$ need not oceur, by any present theory, nor do they occur in actual experiment.

Yellow varicties of mice exist, as Cuénot (1911) reeognizes, in all the color varieties in which non-yellow mice exist. Their external appearanee, however, leads one to identify only six types, namely: (1) black-eyed yellows, brown-eyed 
yellows, black-eyed dilute yellows, and brown-cyed dihte yollows in the "darkeyed" series; (2) pink-eyed yellows and pink-eyod dilutr yollows in the pale series. The experimenter can not distinguish by extermal appearances the black eyed and brown-eyed forms of the pink-eyed yellow series, and so must class them together unless breeding tests be applied.

The "yellow" coat of mice is due to as true a pattern faretor as is the agout i coat, and the investigator errs when he considers the "gellow coat" a lower stage of development of a black or brown coat. Yollow pignent appears in the ticked or agouti coat by the action of a factor whose function jis of a restrictire or inhibitive nature. In a very similar fashion yellow pigment appears on an greater seale in the cuat of the "yellow" mouse.

"Yellow" in mice is no more allelomorphic to gray than is gray allolomorphie to black. Castle, as already stated, has shown that the factor which produees the tieked or gray coat is allelomorphic to its absenee, not to black or any other pigment. It is an exeellent thing to simplify gametic formulie when this ean be done with the support of experimental eridence, but the experimental work should precede the "simplification" unless a false impression is to be produced.

If yellow animals are cerosed with non-ycllow, equality of yollow and nomyellow young is approximated. The following numbers have bero obtained:

\begin{tabular}{|c|c|c|}
\hline & Yellow. & Son-yellow: \\
\hline (H)ierved. & $86 t$ & siz \\
\hline Expected. & 864 & sitiv \\
\hline
\end{tabular}

Several litters of young have been produeed by yellows mated intersesinee the publieation in 1910 of figures showing approxinnately a 2 to 1 ratio. Thes achlitional observations are:

\begin{tabular}{|c|c|c|}
\hline & Íllow. & Non-yellow. \\
\hline (observed ....... & $4 i$ & 20 \\
\hline Expereted, 2-2 to 1 & 4.3 .2 & 226 \\
\hline Expeceterl, 3 to 1 & 51 & 17 \\
\hline
\end{tabular}

If these figures be added to those obtained by Misi Durham (1911), by Cuénot (1903), and by Castle and the writer (1910), the following result is obtained:

\begin{tabular}{|c|c|c|}
\hline & Yellow. & Son-ytllow. \\
\hline $\begin{array}{l}\text { Misis Durham (1911) . . . . } \\
\text { Cuénot (1903) . . } \\
\text { Castle \& Little (1910) . . } \\
\text { Little (1910 and 1911) . . }\end{array}$ & $\begin{array}{r}415 \\
263 \\
1,024 \\
45\end{array}$ & $\begin{array}{l}2: 32 \\
109 \\
3: 34 \\
2 !)\end{array}$ \\
\hline $\begin{array}{l}\text { Total . . . . . } \ldots \\
\text { Expected, } 2 \text { to } 1 \ldots \\
\text { Expected, } 3 \text { to } 1 \ldots\end{array}$ & $\begin{array}{l}1,753 \\
1,752,2 \\
2,004.75\end{array}$ & $\begin{array}{l}8931) \\
891 \\
609.25\end{array}$ \\
\hline
\end{tabular}


The relation of the restriction factor $R$ to the factors $P$ and $D$ has been considered briefly under the head of those factors. The oceurrence of dilute yellow mice, clearly distinguishable from "creams" or "light yellows," was reported by the writer (1911) in the dark-eyed color series. Since that time a few crosses have been made with pink-eyed dilute yellows and they have been found to eonform in their general behavior with other yellow varieties. They apparently can not be obtained in a homozygous state, and when crossed inter se give pink-eyed dilute yellow and pink-eyed dilute non-yellow, as 2 to 1 .

Dilute yellow animals, whether elear, sooty, or sable, are in appearanec more heavily pigmented than are the lightest ereams; but they, as the intense yellows, are found in shades of yellow that vary between eream and deep orange. Any and all dilute yellows have, however, the characteristic streaky, washedout look of the dilute black or dilute brown forms. In crosses, dilute yellows bred inter se have given:

\begin{tabular}{|l|l|c|} 
& $\begin{array}{c}\text { Dilute } \\
\text { yellow. }\end{array}$ & $\begin{array}{c}\text { Dilute } \\
\text { non-yellow. }\end{array}$ \\
\hline Observed. . . . . & 100 & 54 \\
Expected, 2 to 1. & 102.67 & 51.33 \\
Expected, 3 to 1.. & 115.5 & 38.5 \\
\hline
\end{tabular}

It will, then, be seen that dilute yellows, like intense yellows, give a 2 to 1 ratio, the homozygous type being apparently unable to develop.

Dilute yellows crossed with dilute non-yellows have given the following:

\begin{tabular}{|c|c|c|}
\hline & $\begin{array}{l}\text { Dilute } \\
\text { yellow. }\end{array}$ & $\begin{array}{c}\text { Dilute } \\
\text { non-yellow. }\end{array}$ \\
\hline $\begin{array}{l}\text { Observed........ } \\
\text { Expected........ }\end{array}$ & $\begin{array}{l}61 \\
58.5\end{array}$ & $\begin{array}{l}56 \\
58.5\end{array}$ \\
\hline
\end{tabular}

8. Sooty Yellows and Sables.

It is well-known that varieties of yellow mice exist which have a varying amount of dark pigment (brown or black) in the hairs on their dorsal and lateral surfaces; this produees types of yellow known as "sooty yellows" or "sables." The amount of dark pigment varies from a few dark hairs, scattered along the mid-dorsal line, to a condition in which the whole dorsal and nearly all the lateral surfaces are dark, leaving yellow confined to the more ventral portions of the sides and to the belly. A series of arbitrary grades indicating the degree of sootiness has been construeted within the past year. By this means it is hoped to get more accurate ideas as to the nature of sooty yellows. The grades are based upon skins of "sooty" animals and these skins are used as the types by which the living animals are graded. Several experiments have been attempted with the sooty yellows, but all these are still in a preliminary state. Higher numbers of individuals from experiments now in progress may tend to change the conelusions to be drawn from work with this variety. 
The sooty yellows in my stock are most of them homozyon for for hack, i.e., BB. The question arose, how would such sooty forms hehare if crossed with clear yellow lacking $B$. Experimental evidenceshows that sooty yellows having only one dose of $B$ are not as dark as those with two doses.

Thus 7451 sooty (grade $+1 \frac{1}{1}$ ) when crossed with sooty yellow female 7152 $\left(+1 \frac{1}{4}\right)$ gave sooty yellow young, the average grude of which was +1 . The same male when crossed with a brown ( 97730$)$ gave yellow young, the grarles of which averaged +.31 . The writer has never obtained a sooty ycllow or sab!e that did not carry the factor for the production of black pigment $(B)$ in at least half its gametes. Several hundred sooty yellows or sables have heen obtained.

Yellows having one dose of $B$ when erossed inter se should give (besides yellows of their own type) those lacking $B$ entirely as well as those having two doses of $B$. If the "sooty" character segregates, 25 per cent of the yellow animals should approximate the grade of their "sooty" grandparent, 50 per cent should resemble their parents, and 25 per cent should be elear yellow like their other grandparent. A table follows, showing the results of two families in this experiment. The numbers of young are as yet small.

Sooty yellow $\times$ trown.

\begin{tabular}{|c|c|c|c|c|c|c|c|c|c|}
\hline \multirow{2}{*}{$\begin{array}{l}\text { Cirade of } \\
\text { sooty } \\
\text { grand- } \\
\text { imant. }\end{array}$} & \multirow{2}{*}{$\begin{array}{l}\text { No. of } F_{\mathrm{I}} \\
\text { yellow } \\
\text { young. }\end{array}$} & \multirow{2}{*}{$\begin{array}{c}\text { Average } \\
\text { grade of } \\
F_{1} \text { yellows. }\end{array}$} & \multirow{2}{*}{$\begin{array}{l}\text { No. of } F_{2} \\
\text { yellow } \\
\text { young. }\end{array}$} & \multicolumn{5}{|c|}{ Grades of $\mathrm{F}_{2}$ yellow young. } & \multirow{2}{*}{$\begin{array}{l}\text { Average } \\
\text { of } F: \\
\text { yellow } \\
\text { young. }\end{array}$} \\
\hline & & & & 0 & $\therefore 5$ & .50 & .75 & 1.00 & \\
\hline $\begin{array}{l}+25 \ldots \\
+1.25 \ldots\end{array}$ & 12 & $\begin{array}{l}+.06 \\
+.31\end{array}$ & 6 & $\begin{array}{l}7 \\
1\end{array}$ & $\because 2$ & 2 & & 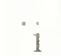 & $\begin{array}{r}+.00 \\
+.42\end{array}$ \\
\hline
\end{tabular}

It will, then, be seen that when the sooty grandparent is of low grade, $+\frac{1}{4}$, nearly clear yellow, his "sooty" character is to all intents and purposes lost in the cross with brown. It fails to reappear in $F_{2}$, so far as the animals obtained are concerned. When the grade of the sooty grandparent is 5 times as great, that is, +1.25 , it will be seen that the average grade of $F_{1}$ is also abont 5 times as great (that is, 0.31 as compared with 0.06 ). Also in $F_{2}$ (larker forms are obtained which may approach the degree of sootiness seen in the grandparent.

Miss Durham (1911) is able to distinguish clearly between "sooty yellows" and "sables." In this eonnection she characterizes "sables" as produced in crossing yellows with blacks or browns. They have a dark black or brown streak down the middle of the back, while the rest of the mouse is yellow. Generally the hairs in the dark streak show a ticked pattern independent of whether the animal carries agouti or not. She has had certain animals (sables) which were dark-pigmented except for a yellow belly. Such animals ahwats molted out sables. She says "sables" are not to be confused with sooty yellows, which result from mating yellow with black, and are dirty color all over with no pattern. She finds that yellows crossed inter se may give "sables," and that "sables" crossed inter se may give yellows, and that matters are 
further complicated by the occurrence of so-called "reversed sables," in which the dark hairs had yellow tips and bases, with a dark subapical band.

The writer must confess that he is unable to draw a clear line between "sables" and "sooty yellows" in all cases. The term sooty yellow is therefore intended in this paper to eover both varieties.

It is possible to explain the appearance of sooty yellows on the basis of fluctuation in activity of the factor $R$, restriction. Thus, when $R$ is present in full strength the animal is clear yellow; if $R$ is slightly weaker, some dark pigment shows itself.

The amount of dark pigment visible becomes progressively greater as the factor $R$ becomes weaker or takes on a rhythmical activity. Thus, if $R$ is hampered in activity during the growth of the first part of the hair, we have a dark tip formed. But if $R$ comes into full activity again, a yellow band results, followed by a second weakening of $R$, resulting in a dlark base to the hair. This would account for the superficial similarity to the agouti pattern. "Reversed sables" may possibly result from a reversal of the order in which the strong and weak periods of $R$ oceur. So, too, those very dark sooty yellows that lack the ticked-hair pattern may be considered due to continued weakness of the factor $R$ during development of the hair of the first coat. When the second coat is formed, however, the factor $R$ makes its appearance felt more strongly and an ordinary type of sable results, with less dark pigment than was present on the first eoat.

In all such eases the idea is present that there is quantitative variation in the activity of the restriction factor $R$, showing itself in the varying amount of black or dark pigment present. If such weakness is due to any interchange of substance between gametes or any quantitative incxactitude in the process of segregation, we should expect that repeated crosses of sooty yellows with blacks would tend to produce much weakened ycllows (i. e., very dark sooty) with much black pigment, as well as modified blacks with some yellow pigment present. While this experiment has not yet been carried to large numbers it may be of interest to record the pedigree of one family:

\begin{tabular}{|c|c|c|}
\hline Generation. & Parents. & Progeny. \\
\hline $\begin{array}{l}\text { III } \\
\text { III }\end{array}$ & $\begin{array}{l}7437 \text { sooty yel. } \times \circ 4346 \text { black } \\
c^{7} 751 \text { sooty yel. } \times \quad 7729 \text { black } \\
\text { o } 1029 \text { sooty yel. } \times\left\{\begin{array}{l}\$ 1027 \\
01033\end{array}\right\} \text { black. }\end{array}$ & $\begin{array}{l}9 \operatorname{soot} y, \text { av. }+.78 \text {, and } 2 \text { blk. } \\
4 \text { soot } y, \text { av. }+1.25 \text {, and } 2 \text { blk. } \\
6 * \text { soot } y \text {, av. }+1.50 \text {, and } 7^{*} \text { blk. }\end{array}$ \\
\hline
\end{tabular}

*Among these sooties was o 1318 (fig. 20) graded + 3, larker by four "one-quarter" grades than any sooty previously obtained. The best previous was +2 . Among theblacks in the same litter was 01316 , the first visibly modified black known to be homozygous in hundreds of black animals that I have seen. His coat is distinctly tawny.

"Sooty yellows" and "sables" have not been reported in the pink-eyed series. This aceords with the results expected by theory, for the modification of the factor $P$, which produces pink-eyed forms, reduces the brown and black 
pigment gramules in the hair to such a degree that we hould experet the dark pigment in the hatrs of kark-eyed "sooty" "yellows, and "sables" to be entirrly" lost in corresponding pink-ered forms.

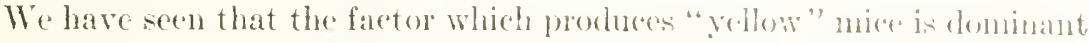
to its absence and is (in function) an inhilitor or lestrictor of lowm and black. It is interesting to compare with this condition the conditions ofsereal in rabbits and guinea-pigs.

In rabhits ("astle (1907b) has shown the occurrelece of the types of " yellow" animak, both of which are hypostatic to non-ycllow formes. The precess of restrietion, if it be such, that produces the yellow type of cout in rabluts is not as extensive as that which produees the clear yellow of mire. Thus all yellow rabbits which lack the factor 4 are, as Castle has shown, sooty; that is, they have considerable black pigment in the hair, which produces not an chear yellow, but a dull or dingy yellow coat. Such a condition, varying or fiuctuating as it cloes in sooty yellows of the same ganctic composition, may be called due to an imperfectly recesive eharacter; that is to say, a condition which shows varying amounts of a dominant character on extracted recessive individuals, may be eonsidered as showing imperfect recesiveness. Such a condition would be more explicable on the grounds that "yedlow" in rabbits appeared as a restriction of black and brown than as a loss of those substances. Yellow in rabbits would then be, aceording to a nomenclature and system suggested by Dr. Castle, due to a semi-potent restrictive factor. By semi-potent is meant a positive character which must be present in all the gametes of an indivichal, for its manifestation in the zygote.

With such semi-potent characters may be contrasted uni-potent characters, which eause visible effect in the zygote when present in onc-half its gametes. An example of this category of factors is seen in the factor $R$, in mice, which we have been diseussing.

In guinea-pigs, however, we secm to have a different condition, in that sooty-yellow animals are very rarcly formed. Thus yellow guinea-pigs extracted as recessive from a hlack race are, in a great majority of cases, clear yellows, whether they are "reds" or light "creams." The occurrence of such clear yellows is more explicahle on a theory demanding loss of brown and black pigment from the skin and hair than from a process of restriction, for it has been seen that restriction is at times an extremely imperfect process, subjecet to frequent fluctuations in degres of activity, while loss is or should be a clear-cut process, removing the possibility of frequent fluctuations by completely removing the materials from which such fluctuations arise.

In studying "yellow" color varieties similarity of color should not have :ufficient value in analysis to argue a common origin of all yellow forms. Discussion of such a question as the origin and physiological significance of different types of yellow must, at least for the present, be based on generalitins, since lefinite evidence is wanting. On the evidence griven by such general fatets, the writ $r$ has above outlined a possible explanation of the obsered conditions, fully realizing, however, that at best such an explanation is incomplete and musat isfactory. 


\section{THE INHERITANCE OF SPOTTING.}

Spotted forms exist in all the various color varieties of mice. Such spotted or piebald animals possess an amount of white varying from a few white hairs to a condition in which pigment oceurs in the eye alone, all the coat being white. Spotting is at present one of the least-understood color phenomena, and further research is necessary before the correetness of any hypothesis concerning it can be proved. Nevertheless, it seems advisable to eonsider the physiologieal nature of spotting and to attempt to eliminate such theories as may be shown, even with our present imperfoet knowledge, to be ineorreet. As stated in the first part of this paper, present ehemical knowledge leads us to the belief that all mammalian pigments are melanins.

Superficially, spotting appears to be partial albinism, and the question naturally arises as to whether it really is due to the same eause or eauses that produce albinism, sueh cause or eauses manifesting their presence in a lesser degree or in a mosaie condition.

Experimental evidenee does not support a theory which postulates the common origin of white produced by spotting and that produced by albinism. If spotting is partial albinism we should expeet, when spotted animals are crossed with albinos, that only spotted or albino animals would be obtained. Among the results olserved by various investigators, none show better the fallacy of this point of view than the elassic experiments of Darbishire (1902) with ('rosses of spotted waltzing mice and albinos of gray (black agouti) aneestry. The appearance of uniformly pigmented animals in the first generation of this cross proved conclusively that the processes produeing the white of spotted eoats and the white of albinos are not only non-identieal, but are fundamentally different.

Since a difference in origin of these two types of white exists, the next matter of interest is to find out whether the differenee lies in the qualitative chemieal make-up of the two whites or in the nature of the distributive proeesses which allow them to appear in the hair.

Experiments learing upon the qualitative nature of the two types of white have been made by Mudge (1909a) on piebald (spotted) and albino rats. He treated the pelage of animals of both these varicties with chemical agents calculated to provide an oxilizing substanee which might act upon the ehromogen in the white portions of the coat, if such a chromogen were present there. He found that the white hairs in both eategories of animals became vellow, both reaeting equally to the agent provided. A few months after the publieation of his work on rats he obtained similar results in pichald and albino miee, by slightly varying the composition of the agent used.

The writer does not poseess sufficient knowledge of chenistry to eomment upon the ultimate value of the work done by Mudge, but in absenee of contrary evidence it seems that his work, especially as it deals with the very types that we are considering, is worthy of confidence and forms a suitable hase from which to draw conclusions. 
If, as Riddle states, it seems absurd to postulate the compleie loss of chromogens in albinos, we must suppose that an enzyme or enzymes have been lost, in order to prevent the formation of pigment. If, now, the work of Mudge shows that the white of spotting lacks the same class of substance as the white of albinism we must say that here also the enzyme or enzymes are absent from the white areas. But by the work of Darbishire, already alluded to, and that of later investigators as well, it is shown that the processes concerned in the origin of the two types of whites are not identical. We must then, by elimination, come to the conclusion that the nature of the processes which control the distribution of the enzyme or enzymes differs in the two categorics.

We have seen that the amount of pigment in the hair of intense pigmented animals is dependent upon the cooperation of two factors, $D$ and $P$. In the wild Mus musculus the pigment occurs distributed over the cntire coat, and the animal is said to be self or uniformly pigmented.

We have supposed that the distribution of pigment is controlled by certain factors. Thus we have supposed that density of pigmentation is controlled by a factor $D$, by the activity of which a certain amount of pigment is formed in eyes and skin and hair. We have recognized a quantitative morlification of this factor in the case of dilute varieties, possessing less pigment. Since this modification affects all three pigments (yellow, brown, and black) and since we have supposed brown and black to be higher oxidation stages of yellow, it seems logical to consider $D$ a factor modifying $Y$, and in this way also modifying $\mathrm{Br}$ and $\mathrm{B}$, which are, so to speak, converted $Y$. When $D$ is modified in amount, less $Y$ is converted to the brown or black stage. This is the condition seen in dilute animals. Logically we should expect another type of modification of $Y$. In self animals $Y$ is distributed over the whole coat. We should expect some forms in which $Y$ was distributed only to certain portions of the body. This modification is seen in the forms in which whitespots occur. Such white areas may be considered as those from which the $Y$-forming substance is absent. Thus the relation of these factors to one another may be roughly shown as follows:

Color producing
substance $Y$$\left\{\begin{array}{c}\begin{array}{c}\text { Distributed in a certain } \\ \text { degree of density }=D \\ \text { Distributed to a certain } \\ \text { extent (self) }=S\end{array} \\ \begin{array}{l}\text { Modified in amount to } \\ \text { form dilute varieties }=d\end{array} \\ \begin{array}{l}\text { Modified in amount to } \\ \text { form spotted varieties }=s\end{array}\end{array}\right.$

If we designate the spotted (piebald) forms by the letter $s$, we may logically consider the unmodificd self forms as being of the constitution $S$. Tic would expect, then, that in crosses between a spotted race of known gametic formula $(s)$ and a self race of formula $(S)$ a mendelian monohybrid ratio would be observed. That such is the case has been recorded by Doncaster (1906) and by Castle and MacCurdy (1907) in the case of "hooded" and self rats. Such a type of spotting as that seen in the hooded rats is, then, a unit character so far as its behavior in crosses is concerned.

Cuénot, working with mice, has found that spotted forms cxist, varying greatly in proportion of white to colored areas. This series of spotted forms he accounts for by supposing that there are present a number of small factors 
for the production of spotting (panachure). These he designates $p_{1}, p_{2}, p_{3}$, $p_{4}$, . . . . cte. Cuénot is by nomeans alone in favoring multiple factors as an explanation for spotting. It is easy and attractive to imagine a factor for every observed degree of spotting The various types of spotted animals seem clear-cut, the colored and white areas seem to form a marked contrast, and the presence of many factors to produce these many forms gives an air of finality to an hypothesis which is alluring.

The advantages of a multiple-factor hypothesis, however, are rendered dubious by the observed occurrence of strains which show that a certain amount of fluctuation exists in the manifestation of even these assumed multiple units. It is questionable whether it woukd be possible to distinguish between a result produced by multiple factors of the number necessary to explain the occurrence of the various spotted forms and a continuous series formed by fluctuation of of the original modification which produces spotting.

Observed experimental facts, however, do not favor a multiple-factor hypothesis. Thus, if multiple factors for spotting existed, the black-eyed white variety would possess the greatest number of these spotting factors. Cuénot in mice and Castle in guinca-pigs found that spotting was recessive to sclf in erosses. Therefore the black-eyed white forms would possess a great number of recessive spotting factors, $p_{1}, p_{2}, p_{3}, p_{1}, p_{5}, p_{6}$, ete. How, then, could two such animals when crossed inter se give in their young practically the whole gamut of spotted forms, as Castle (1905, p. 45), found was the case.

In a somewhat similar way the presence-and-absence hypothesis meets with trouble in the same cross, $i$. e., black-eyed white $\times$ black-eyed white. The spotting from which the black-eycd whites are derived is recessive. It is, therefore, according to the presence-and-absence hypothesis, as advanced by Bateson and Punnett, due to the loss or absence of a factor or factors for uniformity of pigmentation. Tet two animals having, according to this theory, lost the factors for pigment production in the coat, give young which often have a large amount of pigment on the coat. The presence-and-absence hypothesis, in order to explain this ease, must imagine a degree of fluctuation in the manifestation of the spotting eharacter which makes proof of the multiple-factor hypothesis difficult if not impossible.

In the writer's opinion, present knowledge of spotted forms is too scanty to decide whether spotting is due to a process of loss of the factor for uniformity of pigmentation, or to a hypostatic restrictive factor. It seems, howerer, that such spotting as one eneounters in guinea-pigs, hooded rats, and in many mice is a unit character subject to enormous quantitative fluctuation, and that it may be considerel due to a modifieation of the factor $Y$ or $U$ which is hypostatic to unmodified or "self" forms.

In view of the fact that the same substance $I$ is distributed in two different ways to produce spotting and dilution, we may consider it as consisting of an amomnt of pigment $(D)$ distributed over the entire animal $(S)$; therefore we may consicker the pigment of the wild mouse as being designated by the letters DS. An animal may then be of one of the following formula:

DS intense self. Ds intense spotted. dS dilute self. ds dilute spotted. 
We have previously diseused the olservable fluctuations in anount of pigment in animals possessing $D$, for "xample in yellows. The fluctuations observed in the case of spotted animals are lit te if any greater in extrent than the fluctuations from deep orange to cream already noted in the case of yellow mice. If there are two ways ( $d$ and $s$ ) in which the factors $I$ ) and s' may respeetively be modified, we should expect that the same might hold in the case of the factor $P$. The quantitative modifieation of this factor $(p)$, acting upon brown and black pigment to the exclusion of yellow, protuees the pink-eyed colored selies.

If a regional modification of black and brown forming substances ( $\mathrm{Br}$ and $B$ ) existed, we should expeet a spotted condition to be formed. Here, howeror, the spots would be black or brown on a yellow ground. To such a class as this we may say that the tortoise varieties of guinea-pigs belong. This condition is in a measure hypostatic to self-pigmented forms, as are the (s) spotted forms. We have supposed that the factor $P$ produced a certain amount of hlack or brown substance typified by the wild Mus musculus. This fartor, then, appears to bear the same relation to the factors $B r$ and $B$ that the factor $D$ does to the factor $Y$. We may, therefore, logically construct a rough diagram to show the relations of the distributive factors to $B r$ and $B$, as we did in the case of $I^{r}$ :

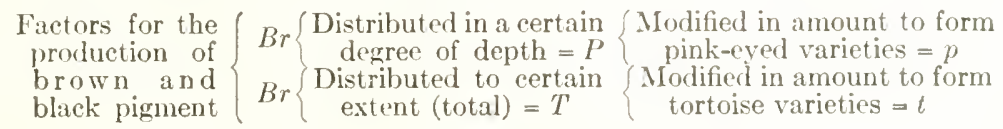

If we designate the tortoise spotting by $t$, we may consicler its epistatic allelomorph as $T$, total or self pigmentation. In this case the factor $P$ becomes complicated, as did the factor $D$, becoming $P T$. As in the ease of the factor $D S$, animals may be of any one of the following formula:

$$
\begin{aligned}
& P T \text { dark-eyed self. } \quad p T \text { pink-eyed self. } \\
& P t \text { dark-eyed tortoise. }
\end{aligned}
$$

In mice we find that the $p$ modification has taken place, while in guineapigs the $t$ modification is well known, and Castle (1912b) has described the origin of a pink-eycd form of guinea-pig which may turn out to be the p modifieation.

It may be seen from the foregoing description that the two forms of spotting (piebald and tortoise) are entirely independent, and it is thus entirely conceivable that they should oceur in the same individual. This appears to be the case in the well-known tri-colored breeds of domesticated animals.

One of the best-known cases of inheritance in tri-colored races is found in the case of "basset" hounds, on which Calton based his "law" of heredity. The character eonsidered was the presence or absence of black in arldition to yellow and white. When black was present the tri-color condition was produced. Though there is no direet rvidence at hand, Bateson (1909), in cliscussing these experiments, states that yellow is not usually lominant to black. If this is the case the observed facts may be explained as follows:

In guinea-pigs the presence of black and yellow spots on any indivintual depends upon the presence of a spotting character which acts upon a totully 
black pigmented animal to produce a blotehed black-and-yellow appearance. For the sake of convenience we may eall animals possessing this "tortoise" marking $t$. All self-black animals lacking this modification, and therefore having no red blotches, are of the formula 'T' Experiments with guinea-pigs (at present being carried on by Dr. Castle) shows that self-black is epistatic to tortoise. This pair of characters is, however, independent from the factors, $E=$ extended black pigmentation, necessary for the production of any black hairs on the coat, and its allelomorph $e=$ the loss of black pigment from the coat, producing yellow animals.

Thus, if a race of tortoise animals existed, formula $E E t t$, we should have a homozygous race of tortoise animals (which in fact exist). If, however, the tortoise animals were of the formula Eett we should expect young of three kinds:
(a) EEtt tortoise.
(b) Eett tortoise.
(c) eett yellow**

Types $(a)$ and $(b)$ having $E$ present would be able to form black pigment on the coat; but type $(c)$, lacking $E$, would be yellow in appearance, though it would be potentially tortoise.

If the factor for spotting with white $(s)$ be added to the formula of a tortoise animal (Eett), we should have, if these animals were bred together, three kinds of young.

(a) EEttss tri-color (tortoise and white).

(b) Eettss tri-color (tortoise and white).

(c) eettss yellow and white.*

Types $(a)$ and $(b)$ would be tri-color, that is, tortoise and white; type $(c)$ would be yellow and white. This might aecount for the appearanee of yellow and white individuals in a race of tri-colored animals.

If, however, yellow were epistatic to black, as in mice, we should have to explain things differently. Tortoise animals could then be of only one formula and would breed true, being recessives, whereas self yellows might also produce tortoise young.

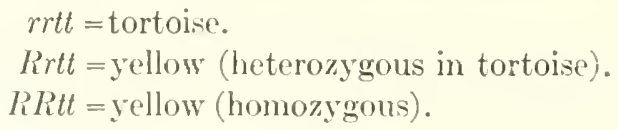

If, now, the modifieation $s$ were added to such hypothetical tortoise animals, we should have

$$
\text { rrttss = tri-eolor (tortoise and white) homozygous. }
$$

If such animals were crossed inter se, we should, on genetie grounds, luave to suppose a change of dominanee to explain the oceurrence of yellow-andwhite young. This does not seem likely. A simple meehanieal fact is, however, able to account for the oecurrence of yellow-and-white animals in an homozygous or heterozygous race of tortoise-and-white (tri-color) animals. Both forms of spotting are independent as to the regions of the coat which they affect. If the white regions should, by chance, coincide with the black regions 
of a tortoise animal we should have an animal yellow-and-white in appearance, though gametically a pure tri-color (tortoise and white). This condition is found in guinea-pigs where two yellow (red) and white animals when crossed together have given young with black on the coat (Castle, 1912), and we know that one of these animals at least must have the gametic composition of a tricolor. In a case of this sort the yellow-and-white animals would occur in ratios entirely free from any mendelian principle, and would give a spurious reversal of dominance.

Perhaps one of the two foregoing suggestions may serve to throw some light on the results upon which Galton's "law" of heredity was based. It must be remembered that tortoise-shell animals are in their gametic composition no more intermediates between black (extended) and yellow (restricted) animals than forms spotted with white are intermediate between colored forms and albinos.

\section{CROSSES WITH JAPANESE WALTZING MICE.}

Morgan (1911a) has mentioned the fact that in crosses between self and spotted forms, in mice, the spotting seemed modified or contaminated by the eross. He gives no figures, however, in support of this statement and fails to mention that the modification of spotted forms by crossing with self was reported by MacCurdy and Castle (1907).

Dr. Castle and the writer have examined earefully the degree of pigmentation of a race of pure Japanese spotted mice and have estimated the percentage of colored area on the dorsal surface; 72 animals were thus examined. The average pigmentation was 32 per cent. The range of pigmentation was from 20 to 55 per cent. Animals of this pure Japanese race were crossed with a uniform self-pigmented race of homozygous dilute brown animals, known to produce no spotted or albino young. $F_{1}$ from these animals consisted of all self pigmented young showing no spots of white. Certain of these $F_{1}$ animals were crossed inter se to obtain $F_{2}$, others were crossed back with females of the pure Japanese race.

In the first case $F_{2}$ was found to consist of 45 self animals (no spots) and 21 animals having some white hairs or spots on the dorsal surface. The 3 to 1 ratio is here approximated, the exact theoretical expectation being 49.5 self to 16.5 spotted. The extracted spotted animals differ widely from the original Japanese race from which they inherited the spotted-coat character. A comparison of the two eategories of spotted forms (together with the back cross, which will be treated later) will be seen in the following table:

\begin{tabular}{|c|c|c|c|}
\hline & $\begin{array}{c}\text { No. of } \\
\text { spotted } \\
\text { individuals. }\end{array}$ & $\begin{array}{l}\text { Average } \\
\text { percentage } \\
\text { of dorsal } \\
\text { surface } \\
\text { pigmented. }\end{array}$ & $\begin{array}{l}\text { Range of in- } \\
\text { dividuals in } \\
\text { percentage } \\
\text { of dorsal } \\
\text { surface } \\
\text { pigmented. }\end{array}$ \\
\hline $\begin{array}{l}\text { (1) Japanese ........ } \\
\text { (2) } F_{2} \text {. . .......... } \\
\text { (3) Back cross . } \\
\text { (4) Back cross } F_{2} \ldots\end{array}$ & $\begin{array}{l}72 \\
21 \\
47 \\
19\end{array}$ & $\begin{array}{l}32 \\
85.3 \\
60.2 \\
70.4\end{array}$ & $\begin{array}{lll}20 & \text { to } & 55 \\
50 & \text { to } & 99 \\
40 & \text { to } & 99 \\
47 & \text { to } & 55\end{array}$ \\
\hline
\end{tabular}


From this table it will besecn that the spotted individuals of $F_{2}$ have been contaminated hy the cross, having their dorsal pigmentation inereased on the average more than 50 per cent over the average of the pure Japanese race. The range of the spotted forms in $F_{2}$ is also very different from that in the Japanese race. There are no $F_{2}$ animals within 18 per cent of the average graele of the Japanese mixe ( 32 per eent); also there is only one $F_{2}$ animal out of 21 that is as lightly pigmented as the darkest of the Japanese race.

The back cross, between $F_{1}$ animals and inclividuals from the pure Japanese race, we should expect to give spolted and self animists in a $1: 1$ ratio. The spotted animals, on a basis of contamination, should not be so extensively modified as in the $F_{2}$ animals; that is, their degree of dorsal pigmentation should be less. There have been 96 animals produced in this back eross, of which 49 are self and 47 spotted, showing that "spotting" amd "self" are still behaving as a pair of allelomorphie characters. The spotted animals from this cross-see ahove table, (3) - hhow an average of 60.2 per cent of the dorsal surface pigmented; their range is from 40 to 99 per rent. This coincides qualitatively with the expectation.

One more eross may be recorled. Certain of the 49 selfs produced by the back eross were bred inter se, thus producing a generation which may be designated as "back cross $F_{2} . "$ spotted animals resulting from this eross, on the theory of contamination, should show a degree of dorsal pigmentation between that of the first $F_{2}$ (85.3 per cent) and of the back eross (60.2 per eent). As a matter of fact the results show that their average pigmentation is 70.4 per cent.

\section{ASSOCIATION OF CHARACTERS.}

The question naturally arises as to whether the various characters are completely independent of each other or whether eoupling or gametic association of any sort exists between some of them. Morgan (1911b) has observed in Drosophila certain results best explained on an hypothesis of "association" of cortain characters in the gamete. It remains to be seen whether any such "assoeiation" of eharacters exists in mice. For this purpose the writer has tabulated the results of four crosses:

I. Cross 10.. Whid Black Agoutr (Mus musculus) Crossen with Dilute Brown.

The black-agouti parent possesses factors $B=$ black, $A=$ agouti, and $D=$ density. The dilute-brown parent lacks the factors $B, A$, and $D$. $F_{1}$ resembles the wild parent. In $F_{2}$ we expect 8 classes, as follows:
(1) Black agouti
$=B r B A D^{*}$
(5) Brown $=B r D$
(2) Black
$=B r B D$
(6) Dilute hro
(7) Dilute black
(S) Dilute brown
$\mathrm{i}=\operatorname{BrAd}$
(3) Brown agouti $=B r A D$
(4) Dilute black agouti $=B r B A d$
$=B r B d$
$=B r d$

*All animals in this cross possess the general color factor $Y$, and the factor for fullness of black and brown pigmentation, $P$. 'They are therefore omitted from the formula for purpose of simplification. 
On an hypothesis of association we should axperet types (1) and (8) to be in excess of the numbers called for by random segregatton. The experimental results are:

\begin{tabular}{|c|c|c|c|c|c|c|c|c|}
\hline$\ldots \ldots \ldots$ & $\begin{array}{c}\text { (1) } \\
l: 1 / 1\end{array}$ & $\begin{array}{l}(2) \\
B / k .\end{array}$ & $\begin{array}{c}\text { (3) } \\
B r \mid l y\end{array}$ & $\begin{array}{l}\text { (1) } \\
\text { Dilutr } \\
\text { li.l! }\end{array}$ & $\begin{array}{l}\text { (5) } \\
\text { limики. }\end{array}$ & $\begin{array}{l}\text { (i) } \\
\text { biluto } \\
\text { lir.ly. }\end{array}$ & $\begin{array}{l}\text { (j) } \\
\text { 1)ilnte. } \\
\text { lik. }\end{array}$ & $\begin{array}{l}\text { (s) } \\
\text { Diliutr } \\
\text { Br. }\end{array}$ \\
\hline olserverl............ & 20 & 9 & 7 & !) & (1) & 4 & 4 & 2 \\
\hline $\begin{array}{l}\text { Expeeded on at batis of } \\
\text { randon segregation. }\end{array}$ & 23 & 7.7 & $7 i$ & 7.7 & 21 & 26 & 2.6 & 1.0 \\
\hline
\end{tabular}

The sum of classes (1) and (s) on a basis of random segregation is 24. "The observed number is less by 2 , showing no signs of association of the characters $A, B$, and $D$.

II. Cross 10. Pink-Lyed Black Agouti Crossed with Dilute Brown Agoutr.

'The pink-eyed black agouti parent posicsaes $B$ ' (black), D) (density), and lacks $P$ (fullness of black and brown pigmentation, dark eye). The dilute

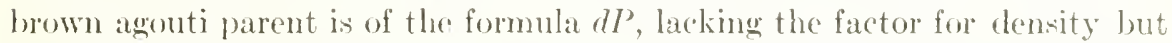
poscessing that for dark eye. If is indistinguishable fron the wid black agouti (Mus musculus).

Pinti-eyed bluck agouti BrpBD $\times$ dilute-broun agouti BrPd.

$F_{1}$ Black agouti, $B B r_{2} P p D$ d

$F_{2}$ (1) Black agouti, BrBPl).1

(2) Brown agouti, BrPDA

(3) Pink-eyeil black agouti, BBrpD.1

(4) Dilute black agouti, BrBP'dA
$F_{2}($ 5) Pink-eyed brown agouti, $B r p D A$

(6) Pink-eyed dilute-bliack agouti, $B r B p d A$

(7) Dilute-lorown agouti, BrPdd

(S) Pink-eyed dilute-brown agouti, BrpdA

Classes (3) and (7) should be in 'xeess if there is any association. The experimental results follow:

\begin{tabular}{|c|c|c|c|c|c|c|c|c|}
\hline & $\begin{array}{c}\text { (1) } \\
B A g .\end{array}$ & $\begin{array}{c}(2) \\
B r i t y .\end{array}$ & $\begin{array}{l}(3) \\
\text { ping. }\end{array}$ & $\begin{array}{l}\text { (4) } \\
\text { dibag. }\end{array}$ & $\begin{array}{c}(\overline{3}) \\
\text { plitag. }\end{array}$ & $\begin{array}{c}(f j) \\
p d B a g .\end{array}$ & $\begin{array}{l}\text { (7) } \\
\text { Atring. }\end{array}$ & $\begin{array}{c}\text { (S) } \\
\text { pilbring }\end{array}$ \\
\hline (observed. & 40 & 13 & 12 & is & 3 & 3 & 5 & 2 \\
\hline $\begin{array}{l}\text { Expected on a basis of } \\
\text { ranrlen segregation. }\end{array}$ & $10 . \overline{1}$ & 13.5 & 13.5 & 13.5 & 4.5 & 1.5 & 4.5 & 1.5 \\
\hline
\end{tabular}

The sum of classes (3) and (7) on a basis of random segregation is 19 , the observed number in the classes is 17 ; again no evidence of association.

III. Cross 66. P'ink-Fyed Black Crossed with Brown.

The pink-eyed black parent possesses the factor $B$ but lacks $P$ and is therefore $B p$; the brown parent lacks $B$ but possesses $P$.

Parents black $B p \times$ brown $P$.

$F_{1}$ Black BPp. $\quad F_{2}(1)$ Black $B P$,
(2) Pink-eyed black $13 p$,
(3) Brown $P$,
(1) Pink-eyed brown p. 
On a basis of association of characters both classes (2) and (3) should be in excess. The observed result follows:

\begin{tabular}{|c|c|c|c|c|}
\hline Classes. & $\begin{array}{c}\text { (1) } \\
\text { Black. }\end{array}$ & $\begin{array}{c}(2) \\
\text { Pink-eyed } \\
\text { black. }\end{array}$ & $\begin{array}{c}(3) \\
\text { Brown. }\end{array}$ & $\begin{array}{l}(4) \\
\text { Pink-eyed } \\
\text { brown. }\end{array}$ \\
\hline Observed. . & 199 & 75 & 61 & 19 \\
\hline Expected on basis of random segregation.... & 199 & 66.3 & 66.3 & 22.1 \\
\hline
\end{tabular}

It will be seen that while type (2), pink-eyed black, is slightly in excess, the browns (which must also on the association hypothesis be in excess) are not. The sum of classes (2) and (3) is 136, while on the supposition of random segregation we should expect 132.6 .

IV. Cross 96. Brown Crossed with Pink-Eyed Dilute-Brown.

Brown possesses both factors $D$ and $P$; pink-eyect dilute brown has neither of them and is $d p$ in formula.

Brown DP $\times$ Pink-eyed dilute brown $d p$.

$F_{1}$ Brown, DdPp. $\quad F_{2}$ (1) Brown, $D P, \quad$ (2) Dilute brown, $d P$, (3) Pink-eyed brown, $D p$, (4) Pink-eyed dilute brown, $d p$.

On an association hypothesis both classes (1) and (4) should be in excess.

\begin{tabular}{|c|c|c|c|c|c|}
\hline Classes. & $\begin{array}{c}\text { (1) } \\
\text { Brown. }\end{array}$ & $\begin{array}{l}(2) \\
\text { Dilute } \\
\text { brown. }\end{array}$ & $\begin{array}{c}\text { (3) } \\
\text { Pink-eycd } \\
\text { brown. }\end{array}$ & $\begin{array}{l}(4) \\
\text { Pink-eyed } \\
\text { dilute } \\
\text { brown. }\end{array}$ & $\begin{array}{l}\text { Sum of } \\
\text { classes (1) } \\
\text { and (4). }\end{array}$ \\
\hline Observed. & 49 & 21 & 3 & 1 & 50 \\
\hline $\begin{array}{l}\text { Expected on a basis of random seg- } \\
\text { regation...................... }\end{array}$ & 41.4 & 13.8 & 13.8 & 4.6 & 46 \\
\hline
\end{tabular}

The sum of classes (1) and (4) is only 4 in excess of the expectation on a basis of random segregation. 'This may be considered as showing no association, because class (4) is not in excess of the expectation. If now we add together the numbers of individuals observed in the classes that should show "association," if it exists, we have 225, while the number called for by the mendelian hypothesis of random segregation is 220.6 , a striking approximation to the observed numbers. We may then conelude that these experiments show no sign of association in the gametes between the factors $D, P, A$, or $B$ or between the four conditions characteristic of their absence. 


\section{PART II. EXPERIMENTAL DATA. EXPLANATION OF SYMBOLS.}

Before giving in cletail the matings made, a few general facts may be stated. In the course of the experiments noted here, more than 10,500 animals have been raised. The independence of all the factors given in this paper has been made certain from breeding tests. The results may first be considered in a general way which may serve, for the present, to show that the factors included in this paper exist as units in inheritance. We may best eonsider the yellow and non-yellow forms under different headings. For non-yellow mice, the results given here are largely eorroborative of evidence previously given by Cuénot, Bateson, Durham, and other investigators.

In expressing the gametic or zygotic formula of the various types we employ a slight modification of the two systems most frequently used. Thus, when a given factor is known to be absent, its symbol is omitted from the formula. For example, the gametic formula of homozygous brown-pigmented animals is given as $Y B r D P$, the zygotic formula $Y_{2} B_{2} D_{2} P_{2}$. Albinos, which are gametically homozygous brown animals, would differ merely in that the color producer $Y$ is absent; they would, therefore, have the gametic formula $B r D P$ and the zygotic formula $\mathrm{Br}_{2} D_{2} P_{2}$. If the original brown race had been heterozygous in the color factor $Y$, its zygotie formula would be ${ }^{y} B r_{2} D_{2} P_{2}$ and the gametes that could be formed would be obviously $Y B r D P$ and $B r D P$.

If, however, we are dealing with such a pair of characters as "dark-eye" $P$ and "pink-eye" $p$, we are not justified in supposing an absence of $P$ in the pink-eyed forms. We merely know that an hypostatic modification of $P$ has occurred, and this is best designated by $p$. If now we have a homozygous brown animal, with the zygotic formula $Y_{2} \mathrm{Br}_{2} \mathrm{D}_{2} P_{2}$, we may designate the homozygous pink-eyed brown as $Y_{2} B r_{2} D_{2} p_{2}$. The dark-eyed brown heterozygous in $P$ would then be $Y_{2} \mathrm{Br}_{2} \mathrm{D}_{2} \mathrm{Pp}$ and would form two sorts of gametes $\mathrm{YBrDP}$ and $Y B r D p$.

It is interesting to note that the system employed by the foremost exponents of the presence-and-absence hypothesis really hints at the presence of two conditions, the one $(B)$ epistatic to the other $(b)$. On the other hand, Castle, who does not follow so implicitly the limits of the presenee-and-absence hypothesis, adopts a system of notation which, in the ease of certain characters, indicates the hypostatic condition by the absence of any symbol to designate it.

The excellent comparative study by Cuénot (1911) has served to make elear many debated points due to variations in systems of notation, and it is therefore with some doubt as to its advisability that the writer advances still a different one. It seems, however, exceeding present knowledge to denote by the same system characters which may obviously be absent and those whose absence is far from proved. 
There should exist, according to the hypothesis advaneed above, S1 types of zygotes in the non-yellow self-colored races. A similar number of types of albinos should also be formed. In the experiments here recorded noeffort has been made to obtain a large number of types of zygotes, yet 58 of the 81 pure colored types have been mot with. The oceurrence of these 58 types is assured hy breeding tests, but it is almost certain that all 81 types have occurred many times in the writer's experiments, since only a very small part of the animals raised has been used for breeding.

A table follows showing the numbers of possible zygotic types, and the number of the observed types in the 16 self-pigmented non-yellow color varieties which are homozygous in the color-produeer $\left(Y^{*}\right)$.

\begin{tabular}{|c|c|c|c|}
\hline Gametic formula. & Description. & Possible. & Observed. \\
\hline 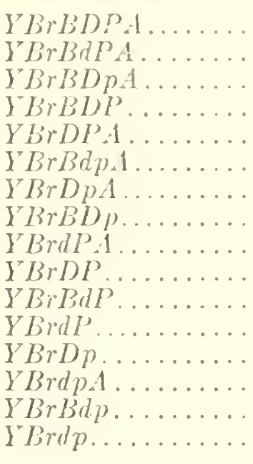 & 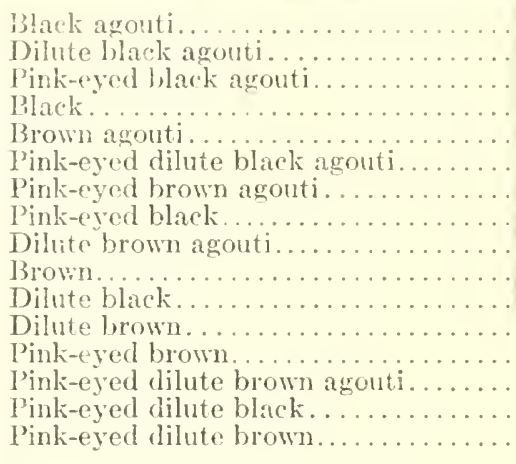 & $\begin{array}{l}16 \\
8 \\
8 \\
8 \\
8 \\
4 \\
4 \\
4 \\
4 \\
4 \\
4 \\
2 \\
2 \\
2 \\
2 \\
2 \\
1\end{array}$ & $\begin{array}{l}8 \\
5 \\
8 \\
5 \\
5 \\
2 \\
3 \\
3 \\
2 \\
4 \\
4 \\
2 \\
2 \\
2 \\
2 \\
1\end{array}$ \\
\hline$Y \operatorname{Brdp} \ldots \ldots \ldots \ldots \ldots$ & & 81 & 58 \\
\hline
\end{tabular}

If yellow animals differ from the non-yellow by the presence of an epistatic restriction factor, $R$, we should expect that the $\$ 1$ zygotic types of nonyellow mice would have their counterpart in the yellow series. Cuénot (1911) reeognizes this fact, but explains it in a slightly different way, which need not le discussed here.

Yellow animals eorresponding with 14 of the 16 non-yellow color varieties have been recognized in breeding tests. The yellows which are potentially dilute brown and those which are potentially pink-eyed dilute-brown agouti are the only forms not as yet demonstrated by breeding tests. There is no reason to suppose that these can not be produced, and it is almost certain that they have occurred among my animals but have not happened to be ehosen for breeding.

The gametic and zygotic formulx used in this part of the paper will be identical with those employed in the first part. A set of abbreviations, given on 1 . 50, will be used in tables. The results here tabulated follow the various experiments through April 15, 1912. 


\section{COLOR VARIETIES OF MICE.*}

1. Hxtended Series (Restriction Factole Miseñ).

1. With the agonti pattern.

Color variety.

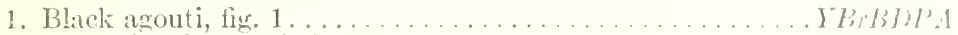

2. Dilute black agouti, fig. 2. . . . . . . . . . . . . . Thrbdl'A

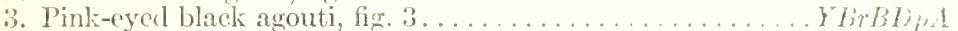

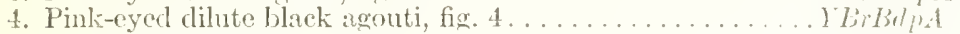

5. Brown agonti, fig. $5 \ldots \ldots \ldots \ldots \ldots \ldots \ldots \ldots \ldots \ldots \ldots \ldots \ldots$ L $\ldots \ldots \ldots$

6. Dilute brown agouti, ficr. $6 \ldots \ldots \ldots \ldots \ldots \ldots \ldots \ldots$. . . . . . . . . . . . .

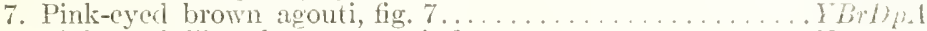

S. Pink-eyed dilute brown agouti, fir. S............. Ybrelpd

Black agouti series

Brown agouti series

\section{\&. Without the agouti pattern.}

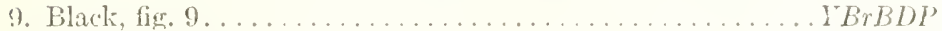

10. Dihute black, fig. $10 \ldots \ldots \ldots \ldots \ldots \ldots \ldots \ldots \ldots \ldots \ldots \ldots$. . . . . . . . . . . . .

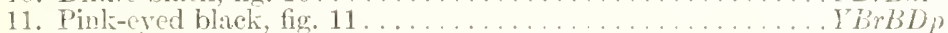

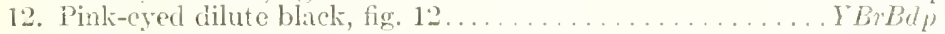

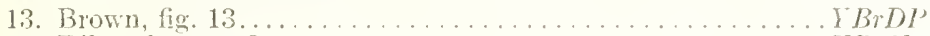

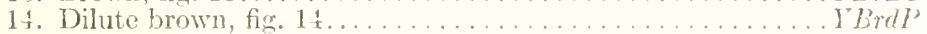

15. Pink-eyed brown, fig. $15 \ldots \ldots \ldots \ldots \ldots \ldots \ldots \ldots \ldots \ldots \ldots \ldots$

16. Pink-eyed clilute brown, fig. $16 \ldots \ldots \ldots \ldots \ldots \ldots \ldots \ldots \ldots \ldots$ Brdp

Black series

Prown serins

B. Restricted Series. Animals in this Series Always Heterozygots in $R$. Color varicty.

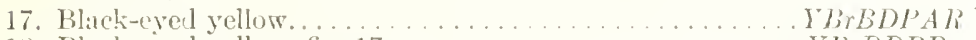

15. Black-eved yellow, fig. 17 ...................... Y

19. Brown-eyed yellow, fig. $15 \ldots \ldots \ldots \ldots \ldots \ldots \ldots \ldots \ldots \ldots \ldots \ldots \ldots$

20. Brown-eyed yellow........................ Y BrDPR

21. Dilute black-eyerl yellow.................... Y BrBdPAL

22. Dilute black-eyed yellow.................... YBrBdPR

23. Diinte brown-eyed yellow. . . . . . . . . . . . . . . . . Y BrdPAK

24. Dilute brown-eyed yellow, fig. $19 \ldots \ldots \ldots \ldots \ldots \ldots$ Y Brdl' $\mathrm{K}$

Dark-eyed intense yellow series

Dark-eyed dilute yellow series

2.5. Pink-eyed yeliow

YBrBDpAR

26. Pink-cyed yellow Y $B r B D p R$

27. Pink-eyed yellow
28. Pink-cyed yellow Y $B r D p A R$

29. Pink-eyed dilute yellow I $\operatorname{BrDpR}$

30. Pink-eyed dilute yellow

IBrBdpAR YBrBdpR

31. Pink-eyed dilute yeliow. . . . . . . . Y $B r d p A R$

32. Pink-eyed dilute yellow Y $\operatorname{BrdpR}$
(Black, brown and yellow Pink-eyed pigment.

Brown and intense yellow series
Black, brown and ycllow pigment

Brown and yellow pig-
Pink-eyed dilute yellow series

There are 32 pigmented varieties of mice which may be obtained in pure races. The "restrieted series," however, may be obtained pure in the sense only that animals may be obtained which give merely the type of yellow witten before their gametic formula, and the single varicty of the "extended" series which the rest of their gametic constitution demands. Albino varieties corresponding with these 32 colored forms are expected to occur and may be produced at will. These albinos are listinguishable from one another only by breeding tests, and it is therefore doubtful whether all the 32 varieties have as yet been isolated.

* The factors $T$ (total pigmentation) and $S$ (self-pigmentation) are not included in these 
In the following pages will be found a brief deseription of the various color varieties, as they appear to the unaided eye, followed by a list of erosses made with each eolor variety. In the tables it has been found expedient to use the following abbreviations to designate in simpler form the eolor varieties, a list of which has already been given:

$$
\begin{aligned}
& B \text { =black, } \quad p=\text { pink-eyerl, } \quad Y \text { =yellow, } \\
& B r=\text { brown }, \quad A g=\text { agouti, } \quad s Y=\text { sooty yeliow, } \\
& d \text { = dilute, } \quad W^{r}=\text { white (albino), } \quad c Y=\text { cream yellow. }
\end{aligned}
$$

Thus, for example, $p d B A g$ is equivalent to pink-eyed dilute black agouti, color variety No. 4 of the extended series.

Unfortunately, in many of the crosses the numbers of animals recorded are small. Aberrations from the expected mendelian ratios of the eolor elasses may also be found in some eases; but an examination of these seem. to indieate that they would diminish with an inerease in the number of animals recorded.

\section{EXTENDED SERIES.}

\section{Bhack Agorti, I'brBDPA (Fig. 1).}

The common coloration seen in the house-mouse (Mus musculus). Eyes black, ears darkly pigmented, hairs on ventral surface tipped with dull-yellowish, then dark slaty to the base. Tail dark-pigmented. Dorsal hairs tipped with black, then having a yellow band and below that being slaty to their base. Such an arrangement produces the "ticked" or "agonti" coat pattern. Tuft of hairs at the base of the ears yellowisha few light hairs on sides, flanks, and feet. Hairs around anus are light.

\section{Black agouti $\times$ black agouti.}

Cross 1. Giving only $B A g$ young; therefore one of the parents, at least, may be considered

\begin{tabular}{|c|c|c|}
\hline Mating. & Parcuts. & $B .1 g$. \\
\hline $\begin{array}{l}74 \\
64 \\
82 \\
14 \\
45\end{array}$ & 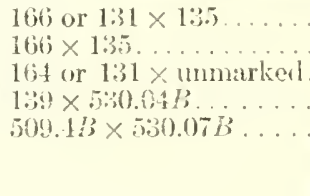 & $\begin{array}{r}6 \\
2 \\
9 \\
11 \\
8 \\
36\end{array}$ \\
\hline
\end{tabular}
homozygous black agouti, type 1 (extended series). The animals used in this eross were descended from yellows.

Cross 2. ${ }_{j}^{3}$ Parents hrterozygous in black. $Y_{2} B r_{2} B_{2} L_{2} P_{2} A_{2} \times Y_{2} B r_{2} B D_{2} P_{2} A_{2}$. Expectation, $3 \mathrm{BA} g$ to $1 \mathrm{BrAg}$.

\begin{tabular}{|c|c|c|c|}
\hline Mating. & I'arents. & B.g. & Brig. \\
\hline 561 & 4914 or $4915 \times 4913 \ldots$ & 7 & 2 \\
\hline
\end{tabular}


Cross 3. Parents heterozygous in color factor and in black. Y $\mathrm{Br}_{2} \mathrm{BD}_{2} \mathrm{P}_{2} \mathrm{~A}_{2} \times \mathrm{YBr}_{2} \mathrm{BD}_{2} \mathrm{P}_{2} A_{2}$. Expectation, $9 \mathrm{BAg}, 3 \mathrm{BrAg}$, to $4 \mathrm{~W}$. The parents in this cross were derived from yellows.

\begin{tabular}{|c|c|ccc|}
\hline Mating. & Parents. & BAg. & BrAg. & W. \\
\hline 45 & $530.02 B \times 16 \ldots \ldots$ & 5 & 5 & 2 \\
\hline
\end{tabular}

Cross 4. Parents heterozygous in black and density. $Y_{2} \mathrm{Br}_{2} B D d P_{2} A_{2} \times Y_{2} \mathrm{Br}_{2} B D d P_{2} A_{2}$. Expectation, $9 \mathrm{BAg}, 3 \mathrm{BrAg}, 3 \mathrm{dBAg}, 1 \mathrm{dBr} A g$.

\begin{tabular}{|c|c|c|c|c|c|}
\hline Mating. & Parents. & $B A g$. & BrAg & $d B A g$ & $d B r A g$. \\
\hline 25 & $530.64 \times 530.54$ & 9 & 4 & 1 & 1 \\
\hline
\end{tabular}

Cross 5. Parents heterozygous in dark eye. $\mathrm{Y}_{2} \mathrm{Br}_{2} \mathrm{~B}_{2} \mathrm{D}_{2} \mathrm{PpA} \mathrm{A}_{2} \times \mathrm{Y}_{2} \mathrm{Br}_{2} \mathrm{~B}_{2} \mathrm{D}_{2} \mathrm{Pp} \mathrm{A}_{2}$. Expectation, $3 \mathrm{BAg}$ to $1 \mathrm{pBAg}$.

\begin{tabular}{|c|c|c|c|}
\hline Mating. & Parents. & BAg. & $p B A g$. \\
\hline 134 & $673 \times 671 \ldots$ & $\mathrm{S}$ & 2 \\
138 & $672 \times 671 \ldots$ & 10 & 1 \\
\hline & & 18 & 3 \\
\hline
\end{tabular}

Cross 6. Parents heterozygous in color factor, dark eye, and agouti. $Y_{B} r_{2} B_{2} D_{2} P p A \times$ $\mathrm{YBr}_{2} \mathrm{~B}_{2} \mathrm{D}_{2} \mathrm{PpA}$. Expectation, $27 \mathrm{BAg}, 9 \mathrm{~B}, 9 \mathrm{pBAg}, 3 \mathrm{pB}, 16 \mathrm{~W}$.

\begin{tabular}{|c|c|c|c|c|}
\hline Mating. & Parents. & BAg. & $p B$. & $\mathrm{W}$. \\
\hline 404 & $2889 \times$ unmarked .... & 2 & 1 & 1 \\
\hline
\end{tabular}

Cross 7. Parents heterozygous in black, dark eye, and agouti. $Y_{2} \mathrm{Br}_{2} B \mathrm{D}_{2} \mathrm{PpA} \times \mathrm{YBr}_{2} B \mathrm{D}_{2} \mathrm{PpA}$. Expectation, $27 \mathrm{BAg}, 9 \mathrm{pBAg}, 9 \mathrm{Br} A g, 9 \mathrm{~B}, 3 \mathrm{pBr} A g, 3 \mathrm{Br}, 3 \mathrm{pB}, 1 \mathrm{pBr}$.

\begin{tabular}{|c|c|c|c|c|c|c|c|c|c|}
\hline Nating. & Parents. & $B A g$. & BrAg. & $B$. & $p B A g$. & $p B r A g$. & $B r$. & $p B$ & $p B r$. \\
\hline $\begin{array}{l}163 \\
119 \\
175 \\
116 \\
140 \\
162 \\
169\end{array}$ & $\begin{array}{l}545 \times 546 \ldots \ldots \ldots \\
547 \times 546 \ldots \ldots \ldots \\
548 \times 546 \ldots \ldots \\
545 \text { or } 548 \times 546 \ldots \\
545-547-548 \times 546 . \\
672-673 \times 918 \ldots \ldots \\
917 \times 918 \ldots \ldots \ldots\end{array}$ & $\begin{array}{r}5 \\
5 \\
7 \\
6 \\
16 \\
5 \\
4\end{array}$ & $\begin{array}{l}5 \\
1 \\
3 \\
3 \\
6 \\
\cdots \\
\cdots\end{array}$ & $\begin{array}{l}3 \\
2 \\
2 \\
2 \\
2 \\
1 \\
1 \\
\cdots\end{array}$ & $\begin{array}{l}3 \\
1 \\
3 \\
\because \\
2 \\
\cdots\end{array}$ & $\begin{array}{l}\cdots \\
\cdots \\
\cdots \\
3 \\
\cdots \\
\cdots\end{array}$ & $\begin{array}{l}1 \\
2 \\
1 \\
2 \\
1 \\
2 \\
2\end{array}$ & $\begin{array}{l}\cdots \\
1 \\
1 \\
1 \\
1\end{array}$ & $\begin{array}{l}\cdots \\
\cdots \\
\cdots \\
\cdots \\
\cdots \\
\cdots\end{array}$ \\
\hline & & $4 \mathrm{~S}$ & 18 & 11 & 9 & 3 & 9 & 4 & . \\
\hline
\end{tabular}


Cross S. I'arents heterozygous in color factor, density, and dark eye. $Y^{\prime} \mathrm{Br}_{2} B_{2} D d P \mathrm{P}_{\mathrm{A}} \mathrm{A}_{2} \times$ $\mathrm{YBr}_{2} \mathrm{~B}_{2} \mathrm{DdPpA}$. Should give $27 \mathrm{BAg}, 9 \mathrm{dBAg}, 9 \mathrm{pBAg}, 3 \mathrm{pdBAg}, 16 \mathrm{~W}$.

\begin{tabular}{|c|c|c|c|c|c|c|}
\hline Mating. & Parents. & BAg. & $d B \perp g$. & plisig. & pllitig. & II. \\
\hline \multirow{3}{*}{$\begin{array}{l}310 \\
-162\end{array}$} & $27.56,2760 \times 27.57$ & 2 & 2 & 1 & 1 & 1 \\
\hline & $2120 \times$ mmarked ... & $\therefore$ & 2 & . & . & . \\
\hline & & $\bar{i}$ & i & 1 & 1 & 1 \\
\hline
\end{tabular}

Cross 9. Parents heterozygous in density, dark eye, and agouti. $\mathrm{r}_{2} \mathrm{Br}_{2} \mathrm{~B}_{2} \mathrm{DdP} p \mathrm{~A} \times$ $\mathrm{Y}_{2} \mathrm{Br}_{2} \mathrm{~B}_{2} \mathrm{DlPpA}$. Expectation, $27 \mathrm{BAg}, 9 \mathrm{pBAg}, 9 \mathrm{~B}, 9 d B A g, 3 p d B A g, 3 d B, 3 p B, 1 \mathrm{pdB}$.

\begin{tabular}{|c|c|c|c|c|c|c|c|c|c|}
\hline Mating. & Parents. & $B A g$. & $d B \perp g$ & b. & $p l i+g$ & 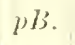 & $p d B .1 g$ & $d B$ & $p d B$. \\
\hline 403 & Cumarked $\times$ unmarked & 9 & $\bar{j}$ & 9 & 1 & 2 & . & & . \\
\hline
\end{tabular}

Cross 10. Parents heterozygous in black, density, and dark eye. $\mathrm{Y}_{2} \mathrm{Br}_{2} B D d P p A_{2} \times$ $\mathrm{Y}_{2} \mathrm{Br}_{2} \mathrm{BDdPpA}$. Expectation, $27 \mathrm{BAg}, 9 \mathrm{pBAg}, 9 \mathrm{BrAg}, 9 \mathrm{dBAg}, 3 \mathrm{pdBAg}, 3 \mathrm{pBrAg}$, $3 d B r i g, 1$ pdBr.Ag.

\begin{tabular}{|c|c|c|c|c|c|c|c|c|c|c|c|}
\hline Mating. & Parents. & $B A g$. & $d B A g$. & $p B A g$. & $B r A g$. & dBrAg. & $p d B A g$. & pBrag. & pdBrAg. & $p-?$ & ? \\
\hline \multirow{7}{*}{$\begin{array}{l}338 \\
199 \\
20: 3 \\
211 \\
27 \bar{j} \\
260\end{array}$} & \multirow{7}{*}{$\begin{array}{r}1290 \times 1289 \\
1291 \times 1289 \\
1293 \times 1289 \\
1291-1293 \\
\times 1289 \\
1290-1291 \\
1293 \times 1289 \\
1539 \times 1289\end{array}$} & 9 & 1 & & 2 & 2 & & & 1 & 1 & \\
\hline & & 5 & 7 & 3 & 4 & 1 & 1 & 1 & - & . & \\
\hline & & 2 & 1 & 3 & 2 & . & & & & & \\
\hline & & 3 & 3 & . & 1 & 1 & . & 1 & . & $\ldots$ & \\
\hline & & 17 & 4 & $j$ & 2 & 1 & 2 & 1 & 1 & 1 & \\
\hline & & 4 & 2 & 1 & 2 & $\ldots$ & .. & & . & 2 & 3 \\
\hline & & 40 & $1 \mathrm{~S}$ & 12 & 13 & 5 & 3 & 3 & 2 & 4 & 3 \\
\hline
\end{tabular}

Cross 10A. Parents heterozygous in black, density, and agouti $Y_{2} \mathrm{Br}_{2} B D d P_{2} A \times Y_{2} B r_{2} B D d P_{2} A$. Expectation, $27 \mathrm{BAg}, 9 \mathrm{dBAg}, 9 \mathrm{BrAg}, 9 \mathrm{~B}, 3 \mathrm{dBr} A g, 3 \mathrm{~dB}, 3 \mathrm{Br}, 1 \mathrm{dBr}$.

\begin{tabular}{|c|c|c|c|c|c|c|c|c|c|}
\hline Mating. & Parents. & BAtg. & $d B: 1 g$. & Br.lg. & $B$. & dBrAg. & $d B$ & $\mathrm{Br}$. & dBr. \\
\hline \multirow[t]{2}{*}{$\begin{array}{ll}1 & 2 \\
1 & 7 \\
1 & 8 \\
11 & 10\end{array}$} & 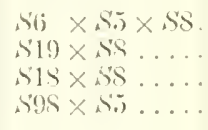 & $\begin{array}{r}7 \\
10 \\
3\end{array}$ & $\begin{array}{l}3 \\
6 \\
\cdots \\
\cdots\end{array}$ & $\begin{array}{l}4 \\
2 \\
1\end{array}$ & $\begin{array}{l}3 \\
4 \\
1 \\
1\end{array}$ & $\begin{array}{l}2 \\
1 \\
1\end{array}$ & $\begin{array}{l}2 \\
2 \\
2\end{array}$ & $\begin{array}{l}. \\
\cdots \\
\ldots\end{array}$ & 1 \\
\hline & & 20 & 9 & 7 & 9 & 4 & 4 & 0 & 2 \\
\hline
\end{tabular}

Black agouti $\times$ dilute black agouti.

Cross 11. Giving only $B A g$ young, both parents liomozygous. $Y_{2} B r_{2} B_{2} D_{2} P_{2} A_{2} \times$ $\mathrm{Y}_{2} \mathrm{Br}_{2} \mathrm{~B}_{2} \mathrm{l}_{2} \mathrm{P}_{2} \mathrm{I}_{2}$.

\begin{tabular}{|c|r|c|}
\hline Miting. & Parents. & B.1 $/$ \\
\hline ti & $131 \times 135$. & 8 \\
\hline
\end{tabular}




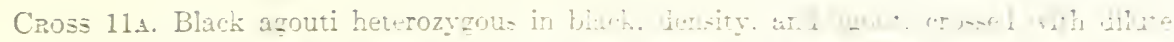

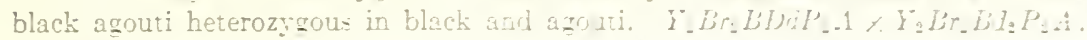

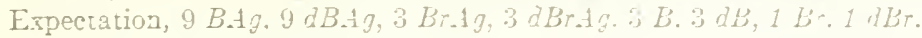

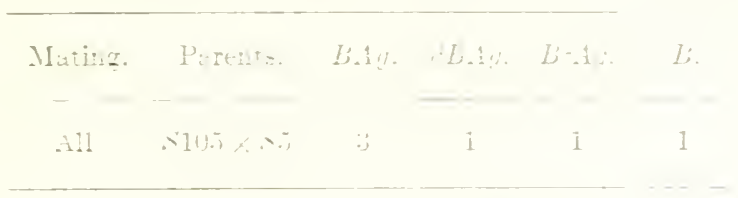

Cross 12. Blach agouti, heterozyous in color factor. biack. Cark fye and argouti. crossed with dilute black agouti heterozyous in color factor, black. dark fye and agouri.

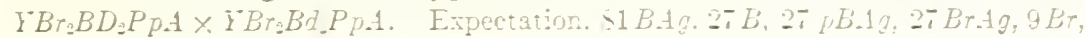
$9 \mathrm{pB}, 9 \mathrm{pBr} A \mathrm{~g}, 3 \mathrm{pBr}, 6 \pm \mathrm{W}$.

\begin{tabular}{|c|c|c|c|c|c|c|c|c|c|}
\hline Mating. & Purent: & $B .1 g$. & B $A$. & l'. & HEA & $B$ & Eir. $\quad, B \cdots .13$ & Br. & W. \\
\hline 1222 & $310.5 \times 3 \frac{1}{4} 94$ & $\overline{7}$ & 3 & $\therefore$ & ; & 1 & & & $j$ \\
\hline
\end{tabular}

\section{Black agouki $\times$ broun ago it.}

Cross 13. Black agouti, heterozygous in black and den-ity crosed with brown agouti hetero

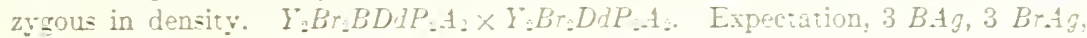
$1 d B . A g, 1 d B r A g$.

\begin{tabular}{|c|c|c|c|c|c|}
\hline Mating. & Purents. & $B A 3$. & Brag. & $d B A g$. & aBrAg. \\
\hline \multirow[t]{2}{*}{$\begin{array}{l}507 \\
37+\frac{1}{1} \\
161\end{array}$} & $\begin{array}{l}\text { Unmarked } \times 3111 \ldots \ldots \\
3115 \times \text { unmarkital } \\
\text { Lnmarked } \times 3114-3115 .\end{array}$ & $\begin{array}{l}1 \\
1 \\
3 \\
6\end{array}$ & $\begin{array}{l}3 \\
\frac{1}{6}\end{array}$ & $\begin{array}{l}1 \\
1 \\
1\end{array}$ & $\begin{array}{l}2 \\
i\end{array}$ \\
\hline & & 11) & 11 & $\because$ & 3 \\
\hline
\end{tabular}

Black: agouti x blact:

Cross 14 . Black agouti heterozygous in the color factor crossed with black heterozygous in

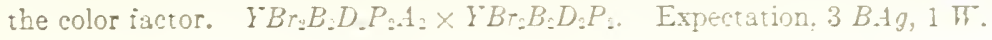

\begin{tabular}{|c|c|c|c|}
\hline Mating. & Purents. & $B A 3$. & $i^{\circ}$. \\
\hline 410 & Cuncurked $\times$ unmarked. & j & 1 \\
\hline
\end{tabular}

Cross 15. Black agouti heterozygous in agouti crossed with homozy gous blac'.

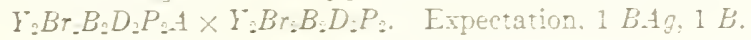

\begin{tabular}{|c|c|c|c|}
\hline Mating. & Pareatio. & BAg. & B. \\
\hline \multirow[t]{2}{*}{$\begin{array}{l}5,5 \\
4.5 \\
A 13\end{array}$} & $\begin{array}{c}721.5 \times 7216 . \\
\therefore 59 \times \\
\therefore-14\end{array}$ & 2 & $\begin{array}{l}5 \\
4 \\
1\end{array}$ \\
\hline & & 11 & 10 \\
\hline
\end{tabular}


Cross 16. Black agout heterozygous in dark eye and agouti erossed with black heterozygous in dark eye. $\quad \mathrm{I}_{2} \mathrm{Br}_{2} \mathrm{~B}_{2} \mathrm{D}_{2} \mathrm{PpA} \times \mathrm{I}_{2} \mathrm{Br}_{2} \mathrm{~B}_{2} \mathrm{D}_{2} \mathrm{Pp}$. Expeetation, $3 \mathrm{BAg}, 3 \mathrm{~B}, 1 \mathrm{pBAg}, 1 \mathrm{pB}$.

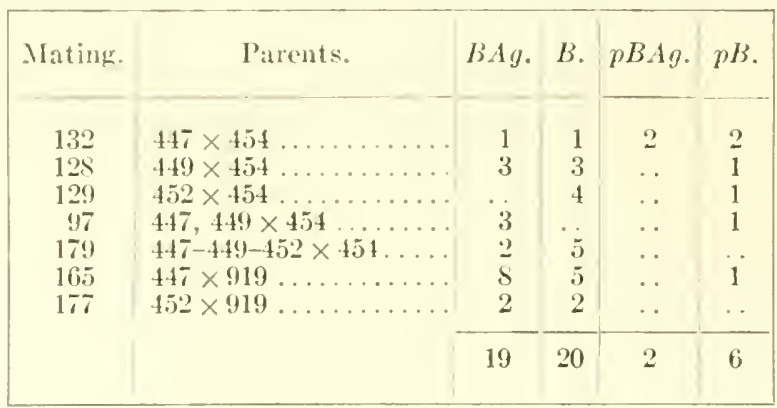

Cross 17. Black agouti heterozygous in blaek, dark eye, and agouti, crossed with black heterozygous in black and dark eye. $Y_{2} \mathrm{Br}_{2} B \mathrm{D}_{2} \mathrm{PpA} \times \mathrm{Y}_{2} \mathrm{Br}_{2} B D_{2} \mathrm{I}^{\mathrm{p} p}$. Expectation, $9 \mathrm{BAg}$, $9 \mathrm{~B}, 3 \mathrm{pBAg}, 3 \mathrm{pB}, 3 \mathrm{BrAg}, 3 \mathrm{Br}, 1 \mathrm{pBrAg}, 1 \mathrm{pBr}$.

\begin{tabular}{|c|c|c|c|c|c|c|c|c|c|}
\hline Mating. & Parents. & $B A g$. & $B$. & $p B A g$. & BrAg. & $B r$. & pBrAg. & $p B$. & $p B r$. \\
\hline $\begin{array}{l}130 \\
107 \\
335 \\
324\end{array}$ & $\begin{array}{l}551 \times 553 \ldots \\
551 \times 671 \ldots \\
2461 \times 2122 \\
2460 \times 2122\end{array}$ & $\begin{array}{l}3 \\
5\end{array}$ & $\begin{array}{l}3 \\
4 \\
4\end{array}$ & $\begin{array}{l}6 \\
1 \\
2\end{array}$ & 1 & $\begin{array}{l}3 \\
1\end{array}$ & $\ddot{1}$ & $\begin{array}{l}1 \\
\cdots \\
\cdots\end{array}$ & $\ddot{2}$ \\
\hline & & 9 & 11 & 9 & 1 & 5 & 2 & 1 & 2 \\
\hline
\end{tabular}

Cross 17A. Black agouti heterozygous in black, density, and agouti, erossed with black heterozygous in density and black. $Y_{2} B r_{2} B D d P_{2} A \times Y_{2} B r_{2} B D d P_{2}$. Expectation, $9 \mathrm{BAg}, 9 \mathrm{~B}, 3 \mathrm{dBA}, 3 \mathrm{~dB}, 3 \mathrm{BrAg}, 3 \mathrm{Br}, 1 \mathrm{dBrAg}, \mathrm{I} d \mathrm{Br}$.

\begin{tabular}{|c|c|c|c|c|c|c|c|c|c|}
\hline Mating. & Parents. & $B A g$. & B. & BrAg. & $B r$. & $d B A g$. & $d B r A g$ & $d B$ & $d B r$. \\
\hline$A 6$ & $S 6 \times S 35$ & 2 & 5 & 3 & 2 & 1 & . & 1 & 1 \\
\hline
\end{tabular}

Black agouti $\times$ broun.

Cross 18. Black agouti heterozygous in blaek erossed with homozygous brown. $\mathrm{Y}_{2} \mathrm{Br}_{2} \mathrm{BD}_{2} \mathrm{P}_{2} \mathrm{~A}_{2} \times \mathrm{Y}_{2} \mathrm{Br}_{2} \mathrm{D}_{2} \mathrm{P}_{2}$. Expectation, $1 \mathrm{BAg}, 1 \mathrm{BrAg}$.

\begin{tabular}{|c|c|c|c|} 
Mating. & l'arents. & BA $g$. & BrAg. \\
\hline 526 & $5943 \times 4920 \ldots$ & 3 & 3 \\
\hline
\end{tabular}

Cross 1S A. Black agouti heterozygous in black and agouti erossed with homozygous brown. $\mathrm{Y}_{2} \mathrm{Br}_{2} \mathrm{BD}_{2} \mathrm{P}_{2} \mathrm{~A} \times \mathrm{Y}_{2} \mathrm{Br}_{2} \mathrm{D}_{2} \mathrm{P}_{2}$. Expectation, $1 \mathrm{BAg}, 1 \mathrm{BrAg}, 1 \mathrm{~B}, 1 \mathrm{Br}$.

\begin{tabular}{|c|c|c|c|c|c|}
\hline Mating. & Parents. & BAg. BrAg. & $B$. & $B r$. \\
\hline$A 1 t$ & $S 6 \times B l z-3001 \ldots$ & $\ldots$ & 2 & 1 & 2 \\
\hline
\end{tabular}


Cross 19. Black agouti heterozygous in color factor, black, and agouti crossed with brown heterozygous in the color factor. $\mathrm{YBr}_{2} \mathrm{BD}_{2} \mathrm{P}_{2} \mathrm{~A} \times \mathrm{YBr}_{2} \mathrm{D}_{2} \mathrm{P}_{2}$. Expectation, $3 \mathrm{BAg}$, $3 \mathrm{~B}, 3 \mathrm{BrAg}, 3 \mathrm{Br}, 4 \mathrm{~W}$.

\begin{tabular}{|c|c|c|c|c|c|c|}
\hline Mating. & Parents. & $B A g$. & $B r A g$. & $B$. & $B r$. & H. \\
\hline 401 & $3306 \times 3307$ & 7 & 1 & 2 & 1 & 5 \\
\hline
\end{tabular}

Black agouti $\times$ dilute broun.

Cross 20. Black agouti heterozygous in color factor, black, and density crossed with dilute brown heterozygous in color factor. $\mathrm{YBr}_{2} B D d P_{2} A_{2} \times \mathrm{YBr}_{2} d_{2} P_{2}$. Expectation, $3 \mathrm{BAg}$, $3 d B A g, 3 \mathrm{BrAg}, 3 \mathrm{dBrAg}, 4 \mathrm{~W}$.

\begin{tabular}{|c|c|c|c|c|c|c|}
\hline Mating. & Parents. & $B A g$. & $d B A g$. & $B r A g$. & $d B r A g$. & $W$. \\
\hline 559 & $-25 \times-89 \ldots \ldots$ & 1 & 2 & 2 & 1 & 1 \\
\hline
\end{tabular}

Cross 20A. Homozygous black agouti $\times$ homozygous dilute brown.

$\mathrm{Y}_{2} \mathrm{Br}_{2} \mathrm{~B}_{2} \mathrm{D}_{2} \mathrm{P}_{2} \mathrm{~A}_{2} \times \mathrm{Y}_{2} \mathrm{Br}_{2} \mathrm{~d}_{2} \mathrm{P}_{2}$. Expectation, all $\mathrm{BAg}$.

\begin{tabular}{|c|c|c|}
\hline Mating. & Parents. & $B A g$. \\
\hline A1 & $S 2 \times S 1 \ldots$ & 8 \\
\hline
\end{tabular}

Cross 20в. Black agouti heterozygous in black and density crossed with homozygous dilute brown. $\mathrm{Y}_{2} \mathrm{Br}_{2} \mathrm{BDdP} \mathrm{P}_{2} \mathrm{~A}_{2} \times \mathrm{Y}_{2} \mathrm{Br}_{2} d_{2} \mathrm{P}_{2}$. Expectation, $1 \mathrm{BAg}, 1 \mathrm{dBAg}, 1 \mathrm{BrAg}, 1 \mathrm{dBr} \mathrm{Ag}$.

\begin{tabular}{|c|c|c|c|c|c|}
\hline Mating. & Parents. & BAg. & BrAg. & dBAg. & dBrAg. \\
\hline A 12 & $309 \times B l z \times 3012$ & 2 & $\cdots$ & 2 & 2 \\
$A 15$ & $3 S 1 \times B l z \times 3012$ & 1 & $\cdots$ & $\cdots$ & 2 \\
\hline & & 3 & $\cdots$ & 2 & 4 \\
\hline
\end{tabular}

Cross 20c. Black agouti heterozygous in black, density, and agouti crossed with homozygous dilute brown. $\mathrm{Y}_{2} \mathrm{Br}_{2} \mathrm{BDd} \mathrm{P}_{2} \mathrm{~A} \times \mathrm{Y}_{2} \mathrm{Br}_{2} \mathrm{~d}_{2} \mathrm{P}_{2}$. Expectation, $1 \mathrm{BAg}, 1 \mathrm{BrAg}, 1 \mathrm{dBAg}$, $1 \mathrm{~B}, 1 \mathrm{dBr} A g, 1 \mathrm{Br}, 1 \mathrm{~dB}, 1 \mathrm{dBr}$.

\begin{tabular}{|c|c|c|c|c|c|c|c|c|c|}
\hline Mating. & Parents. & $B A g$. & BrAg. & $B$. & $d B A g$. & $d B r A g$. & $B r$. & $d B$ & $d B r$. \\
\hline \multirow{4}{*}{$\begin{array}{l}A- \\
A 4 \\
A 9\end{array}$} & \multirow{4}{*}{$\begin{array}{l}373-374 \times S 5 \\
S 6 \times \text { dil. } B r . \\
S 62 \times S 5 \ldots\end{array}$} & 2 & 2 & & 1 & 1 & & 1 & 2 \\
\hline & & 1 & 1 & 4 & 1 & 3 & 1 & . & $\because$ \\
\hline & & 1 & 1 & 1 & 1 & 1 & 2 & . & 1 \\
\hline & & 4 & 4 & 5 & 3 & 5 & 3 & 1 & 3 \\
\hline
\end{tabular}


Black agouti $\times$ pink-cyed brown.

Choss 21. Black agouti heterozygous in dark eye and agouti, crossed with homozygous pinkeyed brown. $Y_{2} \mathrm{Br}_{2} B_{2} D_{2} P \mathrm{PA} \times \mathrm{Y}_{2} \mathrm{Br}_{2} \mathrm{D}_{2} p_{2}$. Expectation, $1 \mathrm{BAg}, 1 \mathrm{pBAg}, 1 \mathrm{~B}, 1 \mathrm{pB}$.

\begin{tabular}{|c|c|c|c|c|c|}
\hline Mating. & Parents. & $B A g$. & pBAg. & b. & $p B$. \\
\hline $39 \mathrm{~s}$ & $330.5 \times p 330 ! \ldots$ & 3 & 7 & 3 & 6 \\
\hline
\end{tabular}

Black agouti $\times$ pink-eyed dilute broun.

Cross 21A. Homozygous black agouti erossed with homozygous pink-eyed dilute brown. $Y_{2} \mathrm{Br}_{2} B_{2} D_{2} P_{2} A_{2} \times Y_{2} \mathrm{Br}_{2} d_{2} p_{2}$. Expectation, all $B A g$.

\begin{tabular}{|c|c|c|}
\hline Mating. & Parents. & $B A g$. \\
\hline \multirow[t]{2}{*}{$\begin{array}{l}626 \\
6330 \\
6333\end{array}$} & \multirow[t]{2}{*}{ 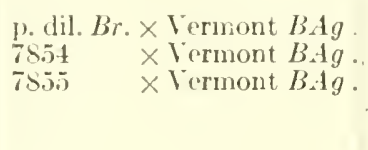 } & $\begin{array}{r}26 \\
\frac{9}{7}\end{array}$ \\
\hline & & 42 \\
\hline
\end{tabular}

Cross 21в. Black agouti heterozygous in black, density, and agouti erossed with homozygous pink-eyed dilute brown. $\mathrm{Y}_{2} \mathrm{Br}_{2} B D d \mathrm{P}_{2} \mathrm{~A} \times \mathrm{Y}_{2} \mathrm{Br}_{2} d_{2} p_{2}$. Expectation, $1 \mathrm{BAg}$, $1 \mathrm{BrAg}, 1 \mathrm{~B}, 1 \mathrm{dBAg}, 1 \mathrm{dBrAg}, 1 \mathrm{Br}, 1 \mathrm{~dB}, 1 \mathrm{dBr}$.

\begin{tabular}{|c|c|c|c|c|c|c|c|c|c|}
\hline Mating. & Parents. & $B A g$. & $\mathrm{BrAg}$. & $B$ & $d B A g$. & $d B r A g$. & $B r$ & $d B$. & $d B r$. \\
\hline \multirow[t]{2}{*}{$\begin{array}{l}A 3 \\
599\end{array}$} & \multirow[t]{2}{*}{$\begin{array}{l}\text { Unmarked } \times S 5 \ldots \ldots \ldots . . . . \\
\text { Unmarked } \times \text { unmarked. }\end{array}$} & $\begin{array}{l}3 \\
1\end{array}$ & 1 & $\begin{array}{l}2 \\
1\end{array}$ & $\begin{array}{l}3 \\
1\end{array}$ & $\begin{array}{l}1 \\
3\end{array}$ & $\begin{array}{l}3 \\
1\end{array}$ & $\ddot{2}$ & $\begin{array}{l}1 \\
\cdots\end{array}$ \\
\hline & & 4 & 1 & 3 & 4 & 4 & 4 & 2 & 1 \\
\hline
\end{tabular}

II. Dilute Black Agouti, YBrBdPA (Fig. 2).

Eyes black, ears moderately pigmented, ventral hairs light slate colored with a yellowish tinge. Tail moderately pigmented. Dorsal hairs showing the "agouti" pattern distinctly but somewhat faded, or washed out in appearance. Tuft of light hairs present at base of the ears and around the anus.

Dilute black agouti $\times$ dilute black agouti.

Cross 22. Both parents homozygous. $Y_{2} \mathrm{Br}_{2} B_{2} d_{2} P_{2} A_{2}$. Expectation, all $d B A g$.

\begin{tabular}{|c|cc|}
\hline Mating. & Parents. & $d B A g$. \\
\hline 621 & $7477 \times$ unmarked... & 12 \\
\hline
\end{tabular}

Cross 22A. Both parents heterozygous in black, dark eye, and agouti. $Y_{2} B r_{2} B d_{2} P p A$. Expectation, $27 d B A g, 9 d B, 9 p d B A g, 9 d B r A g, 3 d B r, 3 p d B, 3 p d B r A g, 1 p d B r$.

\begin{tabular}{|c|c|c|c|c|c|c|c|c|c|}
\hline Mating. & Parents. & $d B A g$. & $d B r i g$. & $d B$. & $p d B A g$ & $p d B r A g$ & $p d B$. & $d B r$. & $p B r$. \\
\hline \multirow[t]{2}{*}{$\begin{array}{l}629 \\
612\end{array}$} & \multirow[t]{2}{*}{$\begin{array}{l}7695 \times 7690-91-92 \\
7694 \times 7690 \ldots \ldots \ldots\end{array}$} & $\begin{array}{l}9 \\
\ldots\end{array}$ & $\begin{array}{l}2 \\
\ldots\end{array}$ & $\begin{array}{l}1 \\
1\end{array}$ & $\begin{array}{l}1 \\
2\end{array}$ & $\begin{array}{l}1 \\
1\end{array}$ & $\begin{array}{l}1 \\
1\end{array}$ & $\begin{array}{l}1 \\
.\end{array}$ & $\begin{array}{l}. \\
\therefore\end{array}$ \\
\hline & & 9 & 2 & 2 & 3 & 2 & 1 & 1 & 0 \\
\hline
\end{tabular}


Dilute black: agouti $\times$ black:

Cross 22B. Dilute black agouti heterozygous in agouti crossed with homozygous bluck.

$\mathrm{Y}_{2} \mathrm{Br}_{2} B_{2} d_{2} P_{2} A \times Y_{2} \mathrm{Br}_{2} B_{2} D_{2} P_{2}$. Expectation, $1 \mathrm{BA}_{4} \mathrm{~A} g$, $1 \mathrm{l}$.

\begin{tabular}{|c|c|c|}
\hline Miating. & P'arents. & $B A g$. \\
\hline 562 & $6106 \times 5 \times 51$ & $\therefore$ \\
\hline
\end{tabular}

Dilute black agouti $\times$ pink-eyed black.

Cross 23. Both parents homozygous. $Y_{2} B_{2} B_{2} d_{2} P_{2} A_{2} \times Y_{2} B_{2} B_{2} D_{2} p_{2}$. Expectation, all $B_{4} A g$.

\begin{tabular}{|c|c|c|} 
Mating. & Purents & $B A g$. \\
323 & $p 45 \times 1871 \ldots$ & $s$ \\
\hline
\end{tabular}

Cross 24. Dilute black agonti heterozygous in black, dark eye, and agouti crossed with pink-eyed black heterozygous in black. $\mathrm{Y}_{2} \mathrm{Br}_{2} \mathrm{Bd} \mathrm{P}_{2} \mathrm{PpA} \times \mathrm{Y}_{2} \mathrm{Br}_{2} \mathrm{BD}_{2} \mathrm{p}_{2}$. Expectation, $3 \mathrm{BAg}, 3 \mathrm{~B}, 3 \mathrm{pBAg}, 3 \mathrm{pB}, 1 \mathrm{BrAg}, 1 \mathrm{Br}, 1 \mathrm{pBrAg}, 1 \mathrm{pBr}$.

\begin{tabular}{|c|c|c|c|c|c|c|c|c|c|}
\hline Mating. & Parentr. & $B .1 g$. & B. & $B i A g$. & Br. & $p B . A g$. & $p B$ & $p B r A g$. & $p B i$. \\
\hline 372 & $p^{2} 685 \times 2400 \ldots$ & 1 & 3 & 1 & 1 & . & . & 4 & . \\
\hline
\end{tabular}

Dilute black agouti $\times$ pink-€yed dilutc black.

CRoss 25. Both parents homozygous. $\mathrm{Y}_{2} \mathrm{Br}_{2} \mathrm{~B}_{2} d_{2} \mathrm{P}_{2} \mathrm{~A}_{2} \times \mathrm{Y}_{2} \mathrm{Br}_{2} \mathrm{~B}_{2} d_{2} \mathrm{p}_{2}$. Expectation, all $d B A g$.

\begin{tabular}{|ccc|}
\hline Mating. & Parents. & $d B A g$. \\
416 & $p 3627 \times$ unmarked.... & 5 \\
\hline
\end{tabular}

Dilute black agouti $\times$ pink-eycd black agouti.

Cross 26. Dilute black agouti heterozygous in dark eye, crossed with pink-eyed black agouti heterozygous in density. $Y_{2} B_{2} B_{2} d_{2} P p A_{2} \times Y_{2} B r_{2} B_{2} D d p_{2} A_{2}$. Expeetation, $1 B A g, 1 p B A g, 1 d B A g, 1 p d B A g$.

\begin{tabular}{|c|c|c|c|c|c|}
\hline Mating. & Parents. & BAtg. & $p B A g$. & $d B A g$. & $p d B A g$ \\
\hline 368 & $2255 \times p 1775$ & & 1 & 1 & . \\
\hline
\end{tabular}

Dilutc black agouti $\times$ pink-eyed dilute black agouti.

Cross 27. Dilute black agouti heterozygous in dark eye crossed with homozygous pinkeyed dilute black agouti. $\mathrm{I}_{2} \mathrm{Br}_{2} \mathrm{~B}_{2} d_{2} \mathrm{Pp}_{\mathrm{A}} \mathrm{A}_{2} \times \mathrm{Y}_{2} \mathrm{Br}_{2} B_{2} d_{2} p_{2} A_{2}$. Expectation, $1 \mathrm{~d} B \mathrm{Ag}$, $1 p d B A g$.

\begin{tabular}{|c|c|c|c|}
\hline Mating. & Parents. & $d B A g$. & $p d B A g$. \\
\hline \multirow[t]{2}{*}{$\begin{array}{l}522 \\
356 \\
560\end{array}$} & $\begin{array}{l}p \text { unmarked } \times \text { unmarked. } \\
p 2.54 \times p 2339 \ldots \ldots \ldots \ldots \ldots\end{array}$ & $\begin{array}{l}3 \\
1 \\
2\end{array}$ & $\begin{array}{l}2 \\
4 \\
\cdots\end{array}$ \\
\hline & & 6 & 6 \\
\hline
\end{tabular}


Dilute black agouti $\times$ broun.

Cross 28. Dilute black agouti heterozygous in agouti crossed with homozygous brown. $\mathrm{Y}_{2} \mathrm{Br}_{2} \mathrm{~B}_{2} \mathrm{~d}_{2} \mathrm{P}_{2} \mathrm{~A} \times \mathrm{Y}_{2} \mathrm{Br}_{2} \mathrm{D}_{2} \mathrm{P}_{2}$. Expeetation, $1 \mathrm{BAg}, 1 \mathrm{~B}$.

\begin{tabular}{|l|c|c|c|}
\hline Mating. & Parents. & Bi $g$. & $B$. \\
\hline 227 & Unmarked $\times$ unmarked $\ldots$ & 3 & 1 \\
\hline
\end{tabular}

Dilute black agouti $\times$ pink-eyed dilute brown.

Cross 2 $\mathcal{S}_{\mathrm{A}}$. Both parents homozygous. $Y_{2} B r_{2} B_{2} d_{2} P_{2} A_{2} \times Y_{2} B r_{2} d_{2} p_{2}$. Expectation, all $d B A g$.

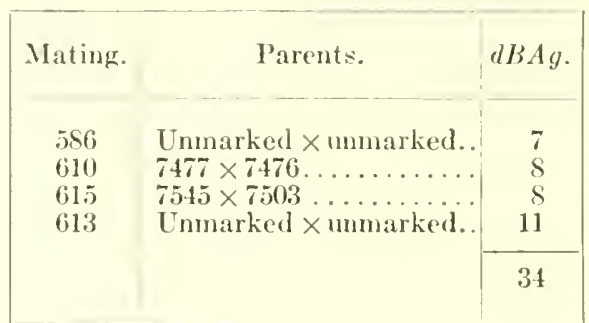

Cross 2SB. Dilute black agouti heterozygous in agouti erossed with homozygous pink-eyed dilute brown. $\mathrm{Y}_{2} \mathrm{Br}_{2} B_{2} d_{2} \mathrm{P}_{2} \mathrm{~A} \times \mathrm{Y}_{2} \mathrm{Br}_{2} d_{2} p_{2}$. Expectation, $1 \mathrm{dBAg}, 1 \mathrm{~dB}$.

\begin{tabular}{|c|c|c|c|}
\hline Mating. & Parents. & $d B A g$. & $d B$. \\
\hline \multirow{3}{*}{$\begin{array}{l}598 \\
617\end{array}$} & \multirow{3}{*}{$\begin{array}{l}\text { Unmarked } \times \text { unmarked } \\
\text { Unmarked } \times \text { unmarked } .\end{array}$} & 4 & 3 \\
\hline & & 4 & 2 \\
\hline & & 8 & 5 \\
\hline
\end{tabular}

Cross 28c. Dilute black agouti heterozygous in black erossed with homozygous pink-eyed dilute brown. $\mathrm{Y}_{2} \mathrm{Br}_{2} B d_{2} P_{2} \mathrm{~A}_{2} \times \mathrm{Y}_{2} \mathrm{Br}_{2} \mathrm{~d}_{2} \mathrm{p}_{2}$. Expectation, $1 \mathrm{dBAg}, 1 \mathrm{dBr} \mathrm{Ag}$.

\begin{tabular}{|c|c|c|c|}
\hline Mating. & Parents. & dBAg. & dBrAg. \\
\hline 585 & Unmarked $\times$ unmarked ... & 4 & 4 \\
\hline
\end{tabular}

Cross 28v. Dilute black agouti heterozygous in black and agouti, erossed with homozygous pink-eyed dilute brown. $\mathrm{Y}_{2} \mathrm{Br}_{2} \mathrm{Bd}_{2} \mathrm{P}_{2} \mathrm{~A} \times \mathrm{Y}_{2} \mathrm{Br}_{2} d_{2} p_{2}$. Expectation, $1 \mathrm{dBAg}, 1 \mathrm{~dB}$, $1 \mathrm{dBrAg}, 1 \mathrm{dBr}$.

\begin{tabular}{c|c|c|c|c|c|}
\hline Mating. & Parents. & $d B A g \cdot$ & $d B$. & $d B r A g$. & $d B r$. \\
\cline { 1 - 3 } 591 & Unmarked $\times$ unmarked... & $\ldots$ & 3 & $\ldots$ & 1 \\
\hline
\end{tabular}


III. Pink-eyed Black Agouti, YBBrDp.1 (Fig. 3).

Eyes very deep pink. Ears apparently unpigmented. Hairs on ventral surface dull yellow with bluish base, showing the presence of the agouti pattern. Dorsal hair elosely resembling that of the dark-eyed brown agouti form to the unaided eye. Nore yellow, however, seems to be present in the coat, though it has been seen that this is not because of an increased amount of yellow pigment. There is a tuft of light hairs at the base of the ears. The hairs directly around the anus, lowever, resemble the other ventral hairs so closely as to be indistinguishable from them.

Pink-eyed black agouti $\times$ pink-eyed black agouli.

Cross 29. One or both parents homozygous. $Y_{2} B_{2} B_{2} D_{2} p_{2} A_{2} \times I_{2} B_{2} B_{2} D_{2} p_{2} A_{2}$. Expectation, all $p B A g$.

\begin{tabular}{|c|c|c|}
\hline Mating. & Parents. & $p B .1 g$. \\
\hline 112 & $560 \times 0.59$. & 15 \\
\hline 130 & $690 \times 691$ & 7 \\
\hline $1 \% 3$ & $689 \times 691$ & $\tilde{5}$ \\
\hline 139 & $692 \times 691 \ldots$ & 16 \\
\hline \multirow[t]{2}{*}{190} & $690-692 \times 691$ & 15 \\
\hline & & 58 \\
\hline
\end{tabular}

Cuoss 30. Both parents heterozygous in black. $Y_{2} B r_{2} B D_{2} p_{2} A_{2} \times Y_{2} B r_{2} B D_{2} p_{2} A_{2}$. Expectation, $3 p B A g, 1 p B r A g$.

\begin{tabular}{|c|c|c|c|}
\hline Mating. & Parents. & $p B .1 g$. & $p B r i g$. \\
\hline \multirow{2}{*}{$\begin{array}{l}1: 0 \\
101\end{array}$} & $55 \times 559 \ldots \ldots$ & 19 & 1 \\
\hline & & , & 5 \\
\hline
\end{tabular}

Cross 31. Both parents heterozygous in black, density, and agouti. $Y_{2} B r_{2} B D d p_{2} A \times$ $Y_{2} \mathrm{Br}_{2} B D d p_{2} A$. Expectation, $27 p B A g, 9 p d B A g, 9 p B r A g, 9 p B, 3 p d B, 3 p d B r A g$, $3 \mathrm{pBr}, 1 \mathrm{pdBr}$.

\begin{tabular}{|c|c|c|c|c|c|c|c|c|c|}
\hline Mating. & Parents. & $p B+g$. & $p d B . \mid g$. & plirag. & $p B$. & $p d B r A g$ & $p d B$. & $p B r$. & $p d B r$. \\
\hline 300 & $2018 \times 2017$ & 17 & 2 & 6 & 3 & & .. & .. & \\
\hline
\end{tabular}

Pink-eyed black agouti $\times$ black.

Cross 32. Pink-eyed black agouti heterozygous in agouti crossed with homozygous black. $\mathrm{Y}_{2} \mathrm{Br}_{2} B_{2} \mathrm{D}_{2} p_{2} \mathrm{~A} \times \mathrm{Y}_{2} \mathrm{Br}_{2} \mathrm{~B}_{2} \mathrm{D}_{2} \mathrm{P}_{2}$. Expectation, $1 \mathrm{BAg}, 1 \mathrm{~B}$.

\begin{tabular}{|r|c|c|c|}
\hline Mating. & Parents. & $B A g$. & $B$. \\
\hline 152 & $416 \times p 109 \ldots$ & 1 & 2 \\
83 & $163 \times p+12 \ldots$ & 2 & 3 \\
\hline & & 3 & 5 \\
\hline
\end{tabular}


I'ink-cyed black agouli $\times$ pink-cycd black.

Cross 33. Both parents homozygous. $Y_{2} B r_{2} B_{2} D_{2} p_{2} A_{2} \times I_{2} B_{2} B_{2} D_{2} p_{2}$. Expectation, all $p B A g$.

\begin{tabular}{|c|c|c|}
\hline Mating. & Parents. & $p B A g$. \\
\hline $\begin{array}{l}1 \pi 1 \\
171\end{array}$ & 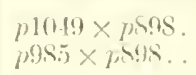 & $\begin{array}{l}4 \\
4\end{array}$ \\
\hline
\end{tabular}

Cross 31. Pink-eyed hlack agout heterozygous in black and agouti crossed with pink-eyed black heterozygous in black. $\mathrm{Y}_{2} \mathrm{Br}_{2} \mathrm{BD} \mathrm{D}_{2} \mathrm{p}_{2} \mathrm{~A} \times \mathrm{Y}_{2} \mathrm{Br}_{2} B \mathrm{~B}_{2} \mathrm{p}_{2}$. Expectation, $3 \mathrm{pBAg}$, $3 \mathrm{pBrAg}, 1 \mathrm{pB}, 1 \mathrm{plir}$.

\begin{tabular}{|c|c|c|c|c|}
\hline Mating. & P'arents. & $p B: 1 g$. & $p B$. & pBriAg. \\
\hline it & $z_{10}^{10} \times p: 12$ & 2 & 2 & 1 \\
\hline
\end{tabular}

Pink-cycd bleck agouti $\times$ dilute black.

Cross 35. Pink-eyed black agouti heterozygous in density crossed with dilute black heterozygous in dark eye. $Y_{2} \mathrm{Br}_{2} B_{2} D d p_{2} A_{2} \times Y_{2} B_{2} r_{2} B_{2} d_{2} P p$. Expectation, $1 B A g, 1 d B A g$, $1 p B A g, 1 p d B A g$.

\begin{tabular}{|c|c|c|c|c|c|}
\hline Mating. & I'arents. & $B A g$. & $d B A g$. & $p B A g$. & $p d B \perp g$. \\
\hline 413 & $3062 \times p 1922$. & 4 & 7 & .. & 7 \\
\hline
\end{tabular}

Pink-eyed black agouti $\times$ dilute broun agouti.

Cross 36. Both parents homozygous. $\mathrm{I}_{2} \mathrm{Br}_{2} \mathrm{~B}_{2} \mathrm{D}_{2} \mathrm{p}_{2} \mathrm{~A}_{2} \times \mathrm{Y}_{2} \mathrm{Br}_{2} \mathrm{~d}_{2} P_{2} \mathrm{~A}_{2}$. Expectation, $B A g$ only.

$$
\begin{aligned}
& \text { Mating. Iarents. Bilg. } \\
& \text { 1S } \quad(522 \times p 691 \ldots 15
\end{aligned}
$$

Cross 37. Homozygous pink-eyed black agouti crossed with dilute brown agouti hetero-

\begin{tabular}{|c|c|c|c|}
\hline Mating. & Parents. & $B A g$. & $p B A g$. \\
\hline 387 & $p$ unmarked $\times 1873$ & 4 & 2 \\
\hline
\end{tabular}
zygous in dark eye. $\mathrm{Y}_{2} \mathrm{Br}_{2} \mathrm{~B}_{2} \mathrm{D}_{2} \mathrm{p}_{2} \mathrm{~A}_{2} \times \mathrm{Y}_{2} \mathrm{Br}_{2} \mathrm{~d}_{2} \mathrm{Y}^{\prime} \mathrm{pA}$. Expectation, $1 \mathrm{BAg}, 1 \mathrm{pBAg}$.

Cross 3S. Pink-eyed black agouti heterozygous in density and agouti crossed with dilute brown agouti heterozygous in agouti. $\mathrm{I}_{2} \mathrm{Br}_{2} \mathrm{~B}_{2} D d p_{2} \mathrm{~A} \times \mathrm{Y}_{2} \mathrm{Br}_{2} d_{2} P_{2} A$. Expectation,

\begin{tabular}{|c|c|c|c|c|c|}
\hline Mintingr. & Parents. & $B .1 \mathrm{~g}$. & dB.tg. & IS. & $d B$. \\
\hline 506 & $p 1.1: 1 \times 460 s$ & 6 & 3 & 1 & 1 \\
\hline
\end{tabular}
$3 B A g, 3 d B A g, 1 B, 1 d B$. 
Cross 39. Pink-eyed black agouti heterozygons in black and density crossed with dilute brown agouti heterozygous in lark eye. $Y_{2} \mathrm{Br}_{2} B D d p_{2} A_{2} \times Y_{2} B r_{2} d_{2} P p A_{2}$. Expectation, $1 B A g, 1 \mathrm{pBAg}, 1 \mathrm{dBAg}, 1 \mathrm{BrAg}, 1 \mathrm{pBr} A g, 1 d B r A g, 1 \mathrm{pdBAg}, 1 \mathrm{pdBrAg}$.

\begin{tabular}{|c|c|c|c|c|c|c|c|c|c|}
\hline Mating. & Parents. & $B A g$. & $p B A g$. & $d B \perp g$ & Bratg. & protg. & ABPAg. & pdBAg. & $p d B r \Lambda g$ \\
\hline \multirow[t]{2}{*}{$\begin{array}{l}369 \\
302 \\
344\end{array}$} & $\begin{array}{l}\text { punmarked } \times 1873 \ldots \\
p 1923-p 1874 \times 1873 \ldots \\
p 1875 \times 1873 \ldots \ldots \ldots\end{array}$ & $\begin{array}{r}10 \\
13 \\
1\end{array}$ & $\begin{array}{l}15 \\
\cdots\end{array}$ & $\begin{array}{l}1 \\
4\end{array}$ & $\begin{array}{l}5 \\
2 \\
2\end{array}$ & & 5 & & . \\
\hline & & 24 & 15 & 5 & 9 & & $j$ & 4 & 1 \\
\hline
\end{tabular}

Pink-eyed black agouti $\times$ brown.

Cross 40. Both parents homozygous. $\mathrm{Y}_{2} \mathrm{Br}_{2} \mathrm{~B}_{2} \mathrm{D}_{2} \mathrm{p}_{2} \mathrm{~A}_{2} \times \mathrm{Y}_{2} \mathrm{Br}_{2} \mathrm{D}_{2} P_{2}$. Expectation, only $\mathrm{BAg}$.

\begin{tabular}{|c|c|c|}
\hline Mating. & Parents. & $B A g$. \\
\hline \multirow{9}{*}{$\begin{array}{l}252 \\
187 \\
286 \\
202 \\
223 \\
195 \\
207 \\
206 \\
235\end{array}$} & $p 1116 \times 1561$. & i) \\
\hline & $p 1125 \times 1527$ & 4 \\
\hline & $p 1533 \times 1405 \ldots \ldots$ & 8 \\
\hline & $p 1396 \times$ unmarked.. & s. \\
\hline & p1368 $\times$ unmarked.. & 5 \\
\hline & $p 1297 \times$ unmarked.. & 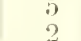 \\
\hline & $\begin{array}{r}1403 \times p 1099 \ldots \\
572 \times p 1099 \ldots \ldots\end{array}$ & $\overrightarrow{0}$ \\
\hline & $1403 \times p 001 \ldots$ & 16 \\
\hline & & 59 \\
\hline
\end{tabular}

Cross 41. Pink-eyed black agouti heterozygous in agouti erossed with homozygous brown. $\mathrm{Y}_{2} \mathrm{Br}_{2} \mathrm{~B}_{2} \mathrm{D}_{2} \mathrm{p}_{2} \mathrm{~A} \times \mathrm{Y}_{2} \mathrm{Br}_{2} \mathrm{D}_{2} \mathrm{P}_{2}$. Expectation, $1 \mathrm{BAg}, 1 \mathrm{~B}$.

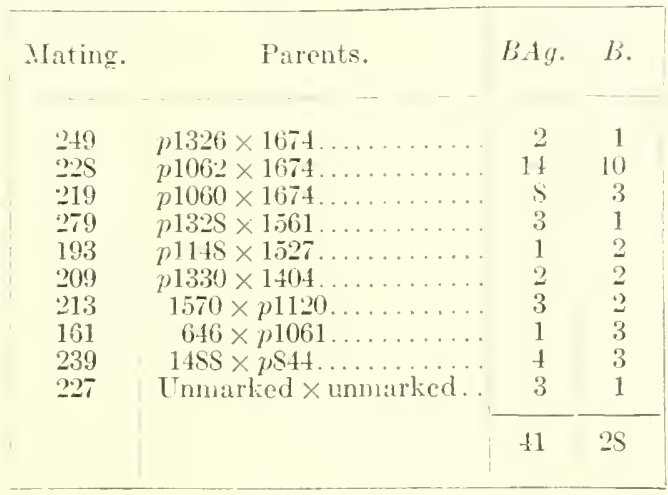

Cross 42. Pink-eyed black agouti heterozygous in black and agouti crossed with homozygous brown. $\mathrm{Y}_{2} \mathrm{Br}_{2} B D_{2} p_{2} \mathrm{~A} \times \mathrm{Y}_{2} \mathrm{Br}_{2} \mathrm{D}_{2} P_{2}$. Expectation, $1 \mathrm{BAg}, 1 \mathrm{~B}, 1 \mathrm{Br} A \mathrm{~g}, 1 \mathrm{Br}$.

\begin{tabular}{|c|c|c|c|c|c|}
\hline MIating. & Parents. & B.1g. & B. & Br. $g$. & $B r$ \\
\hline 253 & $p 1443 \times 1405 .$. & $\ldots$ & 1 & 1 & 2 \\
\hline 332 & $p 1972 \times 2071$. & 4 & 2 & 2 & $\cdots$ \\
\hline & & 4 & 3 & 3 & 2 \\
\hline
\end{tabular}


Cross 43. Pink-eyed black agouti heterozygous in agouti crossed with brown heterozygous in dark cye. $Y_{2} \mathrm{Br}_{2} B_{2} D_{2} p_{2} 1 \times Y_{2} \mathrm{Br}_{2} D_{2} P p$. Expectation, $1 \mathrm{BAg}, 1 \mathrm{~B}, 1 \mathrm{pBAg}, 1 \mathrm{pB}$.

\begin{tabular}{|c|c|c|c|c|c|}
\hline Mating & Parents. & $B A g$. & $p B .1 g$. & $B$. & $p B$. \\
\hline \multirow{4}{*}{$\begin{array}{l}130 \\
181 \\
0 * 31\end{array}$} & \multirow{4}{*}{$\begin{array}{l}1097 \times 1526 \\
1095 \times 1.526 \\
1125 \times 1526\end{array}$} & 1 & & & 1 \\
\hline & & 14 & 11 & 1 & 1 \\
\hline & & 2 & 1 & . & . \\
\hline & & 17 & 12 & 1 & 2 \\
\hline
\end{tabular}

Cross 44. Pink-cyed black agouti heterozygous in density crossed with brown heterozygous in density. $\quad Y_{2} B r_{3} B_{2} D d p_{2} A_{2} \times Y_{2} B_{2} D d P_{2}$. Expectation, $3 B A g, 1 d B A g$.

\begin{tabular}{|c|c|c|}
\hline Mating. & P'arents. & $B A q . \quad d B A q$. \\
\hline 209 & $2179 \times 1922$. & 4 \\
\hline
\end{tabular}

Cnoss 45. Pink-eyed black agouti heterozygous in black, density, and agouti erossed with brown heterozygous in density. $Y_{2} B r_{2} B D d p_{2} A \times Y_{2} B r_{2} D d P_{2}$. Expectation, $3 \mathrm{BAg}$, $3 \mathrm{BrAg}, 3 \mathrm{~B}, 3 \mathrm{Br}, 1 \mathrm{dBAg}, 1 \mathrm{dBr} A \mathrm{~g}, 1 \mathrm{~dB}, 1 \mathrm{dBr}$.

\begin{tabular}{|ccc|c|c|c|c|c|c|c|c|}
\hline Nating. & Parents. & B.1g. & Br.1g. & B. & Br. & dB.1g. & dBrag. & dB. & dBr. \\
\hline 229 & $1710 \times 1405 \ldots$ & $\ldots$ & 6 & 4 & 1 & 1 & $\ldots$ & $\ldots$ & $\ldots$ \\
\hline
\end{tabular}

Cross 46. Pink-eyed black agouti heterozygous in density and agouti, crossed with brown heterozygous in density. $Y_{2} B_{2} B_{2} D d p_{2} A \times Y_{2} B r_{2} D d P_{2}$. Expectation, $3 B A g, 3 B$, $1 d B A g, 1 d B$.

\begin{tabular}{|cc|cc|c|c|}
\hline Mating. & Parents. & B.1g. & d B.1 $g$. & B. & $d B$. \\
\hline & & & & & \\
317 & $1326 \times 1404 \ldots$ & 5 & 2 & 4 & 2 \\
221 & $1332 \times 1404 \ldots$ & 3 & $\because$ & $\because$ & 1 \\
291 & $1326-32 \times 1104$ & 1 & 2 & 4 & $\ldots$ \\
\cline { 3 - 6 } & & 9 & 4 & 8 & 3 \\
\hline
\end{tabular}

IV. Pink-eyed Dildte Black Agouti, YBBrdpA (Fig. 4).

Eycs pink; cars, feet, and tail apparently unpigmented. The color of the coat is markedly washed-out in quality. The agouti pattern is distinguishable, but not casily so, because of the "streaky" due to the abseuce of intense pigmentation. The whole coat resembles a little that of a very light dilute dark-eyed brown agouti. The ear tufts of yellowish hair are prominent. There are no crosses to be included under this variety, though some in which one parent is pink-eyed dilute black agouti have been recorded under the preceding varietics.

\section{T. Brown Agodti, YBrDPA (Fig. 5).}

Fyes a deep rich brown, ears brown pigmented. Hairs on ventral surface yellowish on tip, dull brown at base. Tail brown pigmented. Dorsal hairs brown at the tip, then a yellow band, and finally dull brown to the base, giving the unmistakable "ticked" or "agouti" coat. Whiskers and feet are brown. Light hairs around the anus and at the base of the ears. 
Broun agouti $x$ broun agouti.

Cross 47. One or both parents homozygous. $Y_{2} \mathrm{Br}_{2} \mathrm{D}_{2} \mathrm{P}_{2} \mathrm{~A}_{2} \times \mathrm{Y}_{2} \mathrm{Br}_{2} \mathrm{D}_{2} \mathrm{P}_{2} \mathrm{~A}_{2}$. Expectation, all brown agouti.

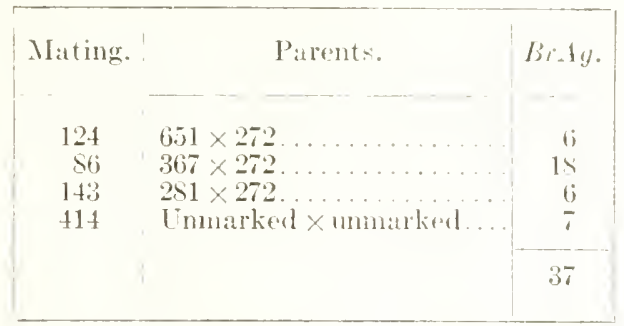

Cross 48. Both parents heterozygous in agouti. $\mathrm{Y}_{2} \mathrm{Br}_{2} \mathrm{D}_{2} \mathrm{P}_{2} \mathrm{~A} \times \mathrm{Y}_{2} \mathrm{Br}_{2} \mathrm{D}_{2} \mathrm{P}_{2} \mathrm{~A}$. Expectation, $3 \mathrm{Br} A g, 1 \mathrm{Br}$.

\begin{tabular}{|c|c|c|}
\hline Ma:ing. & P'arents. & $\mathrm{Br} 1 \mathrm{~g} . \mathrm{Br}$. \\
\hline 104 & in $6 \times 5 \mathrm{~s}$ & 3 \\
\hline
\end{tabular}

Cross 49. Both parents heterozygous in density and the color factor. ${ }^{\prime} \mathrm{Br}_{2} D d P_{2} \mathrm{~A}_{2} \times$ $\mathrm{IBr}_{2} \mathrm{DdY}_{2} \mathrm{~A}_{2}$. Expectation, $9 \mathrm{Br} A \mathrm{~A}, 3 \mathrm{dBrAg}, 4 \mathrm{~W}$.

\begin{tabular}{|c|c|c|c|c|}
\hline Matinge. & P:irents. & BiAg. & abratg. & 11. \\
\hline s. & $511.1 .1 \times 411$ & 3 & 2 & 2 \\
\hline
\end{tabular}

Cross $49 \mathrm{~A}$. Both parents heterozygous in density, dark eye, and agouti. $Y_{2} B r_{2} D d P p A$. Expectation, 27 BrAg, $9 \mathrm{dBr} A \mathrm{~g}, 9 \mathrm{pBr} \mathrm{g}, 9 \mathrm{Br}, 3 \mathrm{pBr}, 3 \mathrm{pdBrAg}, 3 \mathrm{dBr}, 1 \mathrm{pdBr}$.

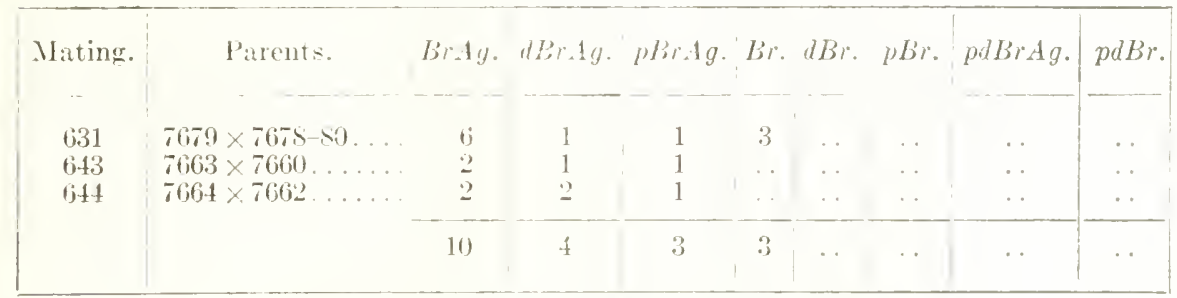

Brown agouti $\times$ pink-eyed brown agouti.

Cross 50. Brown agouti heterozygous in dark-eye, color factor, and agouti crossed with pink-eyed brown agouti heterozygous in the color factor and agouti. $Y^{\prime} B r_{2} D_{2} P p A \times$ $Y \mathrm{Br}_{2} \mathrm{D}_{2} \mathrm{p}_{2} \mathrm{~A}$. Expectation, $9 \mathrm{BrAg}, 9 \mathrm{pBr} \mathrm{Ag}, 3 \mathrm{Br}, 3 \mathrm{pBr}, \mathrm{SW}$.

\begin{tabular}{|c|c|c|c|c|c|c|}
\hline Mating. & Parents. & $\operatorname{Br} 1 \%$. & $B r$. & ${ }_{n} B r+1 g$ & $p B r$ & $W$. \\
\hline \multirow[t]{2}{*}{$\begin{array}{l}407 \\
365 \\
350\end{array}$} & $\begin{array}{l}p \text { unmarked } \times 2735 \ldots \\
p 2137 \times 2735 \ldots \ldots \ldots \\
p 2138 \times 2735 \ldots \ldots \ldots\end{array}$ & $\begin{array}{l}8 \\
\cdots\end{array}$ & $\begin{array}{l}t \\
1 \\
1\end{array}$ & $\begin{array}{l}2 \\
2 \\
2\end{array}$ & $\begin{array}{l}2 \\
\cdots \\
\cdots\end{array}$ & $\begin{array}{l}3 \\
1 \\
1\end{array}$ \\
\hline & & 8 & 6 & 6 & 2 & 5 \\
\hline
\end{tabular}


Brolen agouli $\times$ brown.

Cross 51. Homozygous brown agouti erossed with homozygous brown. $Y_{2} B r_{2} D_{2} P_{2} A_{2} \times$ $\mathrm{X}_{2} \mathrm{Br}_{3} \mathrm{D}_{2} P_{2}$. Expectation, all $\mathrm{Br} \cdot \mathrm{g} g$.

\begin{tabular}{c|c|c|} 
Mating. & l'arents. & Br. $1 g$. \\
90 & $4 S S \times 162 \ldots$ & 6 \\
\hline
\end{tabular}

Cross 52. Brown agonti heterozygous in dark eye and agouti crossed with brown heterozy-

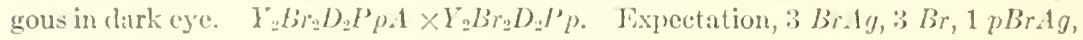
$1 \mathrm{pBr}$.

\begin{tabular}{|c|c|c|c|c|c|}
\hline Mating. & Parents. & BrA $1 \mathrm{~g}$. & $B r$. & $p \operatorname{Br} A g$ & $p B r$. \\
\hline \multirow[t]{2}{*}{$\begin{array}{l}405 \\
305 \\
34 i\end{array}$} & \multirow[t]{2}{*}{$\begin{array}{l}\text { Unmarked } \times \text { mnmarked. } \\
2129 \times 2130 \ldots \ldots \ldots \ldots \\
\text { Ummarked } \times 2130 \ldots \ldots\end{array}$} & 3 & $\begin{array}{l}3 \\
9 \\
6\end{array}$ & $\begin{array}{l}1 \\
5 \\
4\end{array}$ & $\frac{2}{3}$ \\
\hline & & J0) & $1 S$ & 10 & 5 \\
\hline
\end{tabular}

Broun agouti $\times$ pint-eyed brown.

Cross 53. Both parents homozygous. $Y_{2} \mathrm{Br}_{2} I_{2} P_{2} \mathrm{~A}_{2} \times \mathrm{Y}_{2} \mathrm{Br}_{2} \mathrm{D}_{2} \mathrm{p}_{2}$. Expectation, all $\mathrm{Br} / \mathrm{g}$

\begin{tabular}{|c|c|c|}
\hline Mattingr. & Parents. & jis lg. \\
\hline 859 & $p 23\left(0^{\prime}\right) \times 2131 \ldots$ & 4 \\
\hline
\end{tabular}

Brown agouti $\times$ dilute black.

Cross 54. Brown agouti heterozygous in density and agouti, crossed with dilute black heterozygous in black. $Y_{2} B r_{2} D d P_{2} A \times Y_{2} B_{2} B d_{2} P_{2}$. Expectation, $1 \mathrm{BAg}, 1 \mathrm{dBAg}$, $1 \mathrm{~B}, 1 \mathrm{~dB}, 1 \mathrm{BrAg}, 1 \mathrm{dBrAg}, 1 \mathrm{Br}, 1 \mathrm{dBr}$.

\begin{tabular}{|c|c|c|c|c|c|c|c|c|c|}
\hline Mating. & P'arcuts. & bilg. & dis.lg. & $\operatorname{lir}+g$. & mbr.ly. & li. & Br. & $1 / 2$. & $d B r$. \\
\hline 527 & $5351 \times 50303 \ldots$ & 6 & $\therefore$ & 1 & . & 1 & 1 & & .. \\
\hline
\end{tabular}

Brown agouti $\times$ pink-eycd dilute brown.

Cross 54.. Both parents homozygous, $Y_{2} B_{2} D_{2} P_{2} A_{2} \times Y_{2} B r_{2} d_{2} p_{3}$. Expectation, all BrAg.

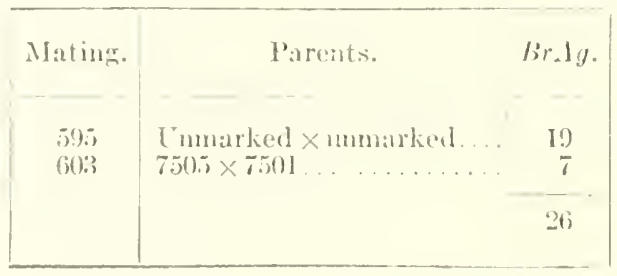

VI. Dilute Brown Agouti, YBrdPA (Fig. 6).

Eyes brown; ears, feet, and tail lightly pigmented with brown. Ventral hairs dull fawn

Dorsal hairs showing the agouti pattern. The whole appearance is that of a dull, faded, intense brown agouti. 
Dilute brown agouti $\times$ pink-eyed dilute brown agouti.

Conoss 55. Dilute brown agouti hetcrozygous in dark eye crosser with hornozygous pinkeyed dilute brown agouti, or pink-eyed dilute brown. $Y_{2} B r_{2} D D_{2} l^{\prime} p_{1} \Lambda_{2} \times Y_{2} B r_{2} d_{2} p_{2}\left(A_{2}\right)$. Expectation, $1 d B r A g, 1$ pdBrilg.

\begin{tabular}{|c|c|c|c|}
\hline Mating. & l'ulents. & dBitalg. & plside. \\
\hline \multirow[t]{2}{*}{$\begin{array}{l}.310 \\
612+2\end{array}$} & $\begin{array}{l}3439 \times 4519 \ldots \\
76,00 \times 8023 \ldots\end{array}$ & 12 & $\begin{array}{r}10 \\
?\end{array}$ \\
\hline & & 13 & 12 \\
\hline
\end{tabular}

Dilute broun agouti $\times$ brown.

Cross 56. Dilute brown agouti heterozygous in dark eye and agouti erossed with brown heterozygous in dark eye. $\mathrm{I}_{2} \mathrm{Br}_{2} d_{2} P p \mathrm{~A} \times \mathrm{Y}_{2} \mathrm{Br} r_{2} \mathrm{D}_{2} \mathrm{Pp}$. Expectation, $3 \mathrm{BrAg}, 3 \mathrm{Br}$, $1 \mathrm{pBrAg}, 1 \mathrm{pBr}$.

\begin{tabular}{|c|c|c|c|c|c|}
\hline Matiug. & Parents. & Firlg. & $B i$. & $p \operatorname{sir} 1 g$. & $p l s i$. \\
\hline t.28 & $3139 \times 3739$ & 12 & $i$ & 1. & 2 \\
\hline
\end{tabular}

VII. Pink-Eyed Brown Agouti, YBrDph (Fig. 7).

Eyes clear pink; ears apparently unpigmented, as are also feet and tail. Hairs on ventral surface indistinguishable superficially from a deep pink-eyed yellow. When examined more closely they are found to be darker at the base than at the tip, showing the presence of the agouti pattern. Dorsal hair a very rich brownish yellow and deeper colored at the base with dull brownish pigment. Because of the reduction of brown pigment at the tips of the hairs the appearance of banding or "ticking" is almost entirely" wanting. Whiskers, hairs at base of ears, and around the anus are yellow.

Pink-eyed broun agouti $\times$ pink-eyed brown agouti.

Clioss 57. Both parents heterozygous in agouti. $\mathrm{Y}_{2} \mathrm{Br}_{2} D_{22} p_{2} \mathrm{~A} \times \mathrm{Y}_{3} \mathrm{Br}_{2} D_{22} p_{2} \mathrm{~A}$. Expectation, $3 \mathrm{pBrAg}, 1 \mathrm{pBr}$.

\begin{tabular}{|c|c|c|c|}
\hline Mating. & Parents. & pBrAg. & $p B r$. \\
\hline 419 & $p$ unmarked $\times p 2903 \ldots$ & 6 & 1 \\
399 & $p 3109 \times p 2903 \ldots \ldots \ldots$ & 1 & 1 \\
& & 10 & 2 \\
\hline
\end{tabular}

Cross 58. Both parents heterozygous in density and agouti. $y_{2} \mathrm{Br}_{2} D d p_{2} \mathrm{~A} \times \mathrm{Y}_{2} B r_{2} D d p_{2} \mathrm{~A}$. Expectation, $9 \mathrm{pBr} A g, 3 \mathrm{pBr}, 3 \mathrm{pdBr} / \mathrm{g}, 1 \mathrm{pdBr}$.

\begin{tabular}{|c|c|c|c|c|c|}
\hline Mating. & Parentio & pbidg. & pBr. & pdBr.1g. & $p d B r$. \\
\hline 400 & $p 2904 \times p 2903 \ldots$ & 2 & 2 & 1 & $\ldots$ \\
\hline
\end{tabular}


l'ink-eyed brown agouti $\times$ brown.

Cross 59. Both parents homozygous. $\mathrm{Y}_{2} \mathrm{Br}_{2} \mathrm{D}_{2} \mathrm{p}_{2} \mathrm{~A}_{2} \times \mathrm{Y}_{2} \mathrm{Br}_{2} \mathrm{D}_{2} \mathrm{P}_{2}$. Expectation, $\mathrm{Br} \mathrm{Ag}$ only.

\begin{tabular}{|cc|c|}
\hline Mating. & l'arents. & BrAg. \\
\hline 360 & $p$ unmarked $\times 2393 \ldots$ & 1 \\
\hline
\end{tabular}

Cross 60. Homozygous pink-eyed brown agouti crossed with brown heterozygous in dark eye. $\mathrm{Y}_{2} \mathrm{Br}_{2} \mathrm{D}_{2} \mathrm{p}_{2} \mathrm{~A}_{2} \times \mathrm{Y}_{2} \mathrm{Br}_{2} \mathrm{D}_{2} \mathrm{P} \mathrm{p}$. Lxpectation, $1 \mathrm{BrAg}, 1 \mathrm{pBrAg}$.

\begin{tabular}{|c|c|c|c|}
\hline Maling. & larents. & $B r A g$. & $p B r A g$. \\
\hline 261 & $p 1395 \times 1526 \ldots \ldots \ldots$ & 9 & 4 \\
\hline
\end{tabular}

ViII. Pink-eyen Dilute Brown Agouti, YBrdpA (Fig. S).

Eyes pink; cars, tail, and feet very lightly pigmented with brown. In both ventral and dorsal hairs this form resembles a dull intense pink-eyed brown agouti, differing chiefly in the comparative laek of bright yellow pigment and in the mealy, washed-out look. The agouti pattern is very weak indeed.

Pink-eyed dilute brown agouti $\times$ pink-eyed dilute brown agouti.

Cross 61. Both parents heterozygous in agouti. $\mathrm{I}_{2} \mathrm{Br}_{2} d_{2} p_{2} \mathrm{~A} \times \mathrm{Y}_{2} \mathrm{Br}_{2} \mathrm{~d}_{2} \mathrm{p}_{2} \mathrm{~A}$. Expectation, 3 pdBrAg, 1 pdBr.

\begin{tabular}{|c|c|c|cc|}
\hline Mating. & l'arents. & $p d B r A g$. & $p d B r$. & $p ?$ \\
\hline 479 & Unmarked $\times p 4519 \ldots$ & 1 & 2 & $\ldots$ \\
\hline 535 & $p 4213 \times p 4519 \ldots \ldots$ & 1 & $\ldots$ & 3 \\
\hline & & 2 & 2 & 3 \\
\hline
\end{tabular}

Pink-eyed dilute brown agouti $\times$ dilute broun.

Cross 61 A. Pink-eyed dilute brown agouti heterozygous in agouti erossed with dilute brown heterozygous in dark ey'e. $\mathrm{Y}_{2} \mathrm{Br}_{2} d_{2} \mathrm{p}_{2} \mathrm{~A} \times \mathrm{Y}_{2} \mathrm{Br} r_{2} d_{2} \mathrm{Pp}$. Fxpeetation, $1 \mathrm{dBr} A \mathrm{~g}, 1 \mathrm{dBr}$, $1 p d B r A g, 1 p d B r$.

\begin{tabular}{|c|c|c|c|c|c|}
\hline Mating. & Parents. & ABrAg. & $d B r$. & pdBisy. & $p d B r$. \\
\hline \multirow[t]{2}{*}{$\begin{array}{l}596 \\
6965\end{array}$} & \multirow[t]{2}{*}{$\begin{array}{l}\text { Unmarked } \times \text { mmmarked } \\
7471 \times 7 \text { t } 6 . \ldots \ldots \ldots \ldots\end{array}$} & $\begin{array}{l}1 \\
2\end{array}$ & 3 & $\begin{array}{l}1 \\
2\end{array}$ & $\frac{2}{1}$ \\
\hline & & 3 & 3 & 3 & 3 \\
\hline
\end{tabular}

Cross $61 \mathrm{n}$. Both parents homozygous. $\mathrm{Y}_{2} \mathrm{Br}_{2} \mathrm{~d}_{2} p_{2} \mathrm{~A}_{2} \times \mathrm{Y}_{2} \mathrm{Br}_{2} \mathrm{~d}_{2} \mathrm{P}_{2}$. Expectation, all $\mathrm{d} \mathrm{Br} \mathrm{Ag}$.

\begin{tabular}{|c|c|c|}
\hline Mating. & l'arents. & $d B r A g$ \\
\hline 609 & Unmarked x unmarked. & 2 \\
\hline
\end{tabular}


IX. BLACK, YBIBDP' (IIT. 9).

Hairs on ventral surface not so heavily pigmented as the torsal hairs, and of a dull slaty

blaek. Tail dark. Dorsal hairs deep, glossy black. 'Tuft of yellowish hatirs at loase of ears. A few yellowish hairs seattered along the flimks, siles and foet. The hairs around the anus are light yellowish. The feet are dark.

\section{Black $\times$ black.}

Cross 62. One or both of the parents homozygous. $Y_{2} B_{2} B_{3} D_{2} P_{2} \times Y_{2} B_{3} B_{2} D_{2} P_{2}$. Lxpectation, all $B$.

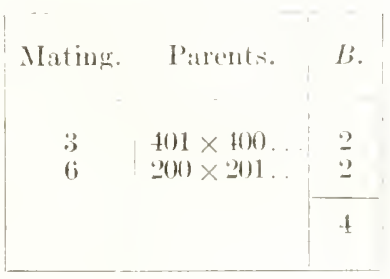

Cross 63. Both parents heterozygous in black. $Y_{2} B r_{2} B D_{2} P_{2} \times Y_{2} B r_{2} B D_{2} P_{2}$. Expectation, $3 B, 1 \mathrm{Br}$.

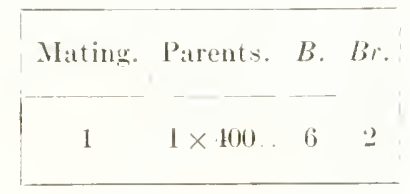

Cross 64. Both parents heterozygous in density. $Y_{2} B_{2} B_{2} B_{1} d P_{2} \times Y_{2} B r_{2} B_{2} D d P_{2}$. Expeetation, $3 B, 1 d B$.

\begin{tabular}{|cccc|}
\hline Mating. & Parents. & b. & $d B$. \\
\hline 577 & $7214 \times 7217 \ldots$ & 3 & 3 \\
\hline
\end{tabular}

Cross 65. Both parents heterozygous in lark eye. $\quad Y_{2} B r_{2} B_{2} D_{2} P p \times Y_{2} B r_{2} B_{2} D_{2} P p$. Expeetation, $3 B, 1 \mathrm{pB}$.

\begin{tabular}{|c|c|c|c|}
\hline Mating. & Parents. & b. & $p l$. \\
\hline 492 & Comarker $\times 2948$ & 3 & 1 \\
\hline 105 & $4.5 \times 9919 \ldots \ldots$ & 12 & 1 \\
\hline 189 & $450 \times 510 \ldots \ldots$ & ci & 2 \\
\hline 114 & Unmarked $\times 4.54$. & 12 & 1 \\
\hline 131 & $543 \times 144 \ldots \ldots$ & 2 & 1 \\
\hline 13.5 & $450 \times 414 \ldots \ldots \ldots \ldots$ & 7 & 1 \\
\hline \multirow[t]{2}{*}{379} & Unmarked $\times$ ummarked . & 60 & 2) \\
\hline & & 102 & 30) \\
\hline
\end{tabular}


Cross 66. Both parents heterozygous in dark eye and black. $\mathrm{Y}_{2} \mathrm{Br}_{2} \mathrm{BD}_{2} \mathrm{Pp} \times \mathrm{Y}_{2} \mathrm{Br}_{2} \mathrm{BD} \mathrm{D}_{2} \mathrm{Pp}$. Expectation, $9 \mathrm{~B}, 3 \mathrm{pl}, 3 \mathrm{Br}, 1 \mathrm{pBr}$.

\begin{tabular}{|c|c|c|c|c|c|c|}
\hline Mating. & Parents. & B. & $p B$. & $B r$. & $p B r$. & $p ?$ \\
\hline 361 & $2596 \times 2593 \ldots \ldots$ & 2 & 1 & & & \\
\hline $376 a$ & Unmarked $\times$ unmarked... & $7 S$ & 26 & 23 & 5 & 1 \\
\hline $376 b$ & Unmarked $\times$ unmarked.. & 13 & 7 & 5 & 2 & \\
\hline 247 & $1706 \times 541 \ldots \ldots \ldots \ldots \ldots$ & 2 & 1 & & 1 & .. \\
\hline 318 & $2031 \times 1942$. & S & 2 & 4 & & .. \\
\hline 316 & $194 S \times 1950 \ldots \ldots$ & 5 & 4 & 2 & 1 & .. \\
\hline $26 \pi$ & $19.48 \times 1949-1950$. & 3 & & 1 & . & . \\
\hline 361 & $2084 \times 2086 \ldots \ldots$ & 2 & $\ddot{3}$ & 2 & 1 & $\cdots$ \\
\hline $\begin{array}{l}303 \\
295\end{array}$ & $\begin{array}{l}2081-20 S 5 \times 2086 \\
21 S 6-87-S 8-89 \times 21 S t .\end{array}$ & $\begin{array}{l}11 \\
31\end{array}$ & $\begin{array}{r}3 \\
16\end{array}$ & $\begin{array}{l}3 \\
6\end{array}$ & $\begin{array}{l}1 \\
4\end{array}$ & $\cdots$ \\
\hline 349 & $2212 \times 2213 \ldots \ldots \ldots$ & $\tau$ & 4 & 2 & . & $\cdots$ \\
\hline 334 & $2218 \times 2213$ & 6 & 5 & 2 & & . \\
\hline 358 & $2210 \times 2219 \ldots$ & 4 & & 1 & 1 & .. \\
\hline 333 & $2210-14 \times 2219$. & 15 & 2 & 6 & & \\
\hline 444 & $2216 \times 2219 \ldots \ldots$ & 4 & 2 & & 1 & .. \\
\hline 336 & Unmarked $\times 2593 \ldots \ldots \ldots$ & 7 & 1 & 3 & 3 & . \\
\hline \multirow[t]{2}{*}{$44 \pi$} & \multirow[t]{2}{*}{$2945 \times$ ummarked......... } & 1 & 1 & 1 & . & $\cdots$ \\
\hline & & 199 & 75 & 61 & 19 & 1 \\
\hline
\end{tabular}

Cross 66A. Both parents heterozygous in black, dark eye, and density. $Y_{2} B r_{2} B D d P p$. Expectation, $27 \mathrm{~B}, 9 \mathrm{~dB}, 9 \mathrm{pB}, 9 \mathrm{Br}, 3 \mathrm{pBr}, 3 \mathrm{dBr}, 3 \mathrm{pdB}, 1 \mathrm{pdBr}$.

\begin{tabular}{|c|c|c|c|c|c|c|c|c|c|}
\hline Mating. & Parents. & $B$. & $d B$. & $p B$. & $B r$. & $p d B$. & $p B r$. & $d B r$. & $p d B r$. \\
\hline 619 & $7515 \times 7513-14-16 \ldots$ & 4 & 2 & 6 & 2 & 1 & $\ldots$ & $\ldots$ & $\ldots$ \\
645 & $7431 \times 7514 \ldots \ldots$ & 3 & $\ldots$ & $\ldots$ & 2 & 1 & $\ldots$ & $\ldots$ & $\ldots$ \\
\hline 646 & $7733 \times 7734 \ldots \ldots$ & 3 & $\ldots$ & $\ldots$ & $\ldots$ & $\ldots$ & $\ldots$ & $\ldots$ & $\ldots$ \\
\hline
\end{tabular}

Cross 66в. Both parents heterozygous in color factor, black, dark eye, and density. $Y B r_{2} B D d P p$. Expectation, $81 B, 27 d B, 27 p B, 27 B r, 9 p B r, 9 d B r, 9 p d B, 3 p d B r$, $64 \mathrm{~W}$.

\begin{tabular}{|c|c|c|c|c|}
\hline Mating. & Parents. & B. & Br. & $W^{+}$ \\
\hline 625 & $7430 \times 7428 \ldots$ & 5 & 5 & 3 \\
\hline
\end{tabular}

Black $\times$ dilute black.

Cross 67. Both parents homozygous, $Y_{2} \mathrm{Br}_{2} B_{2} D_{2} P_{2} \times Y_{2} \mathrm{Br}_{2} B_{2} d_{2} P_{2}$. Expectation, all $B$.

\begin{tabular}{|c|c|c|} 
Mating. & Parents. & $B$. \\
\hline 552 & $4865 \times 5789 \ldots$ & 2 \\
\hline
\end{tabular}


Cross 68. Both parents heterozygous in dark eye. $Y_{2} B r_{2} H_{2} H_{2} P p \times Y_{2} B_{r_{2}} B_{2} d_{2} P p$. Expectation, $3 B, 1 p B$.

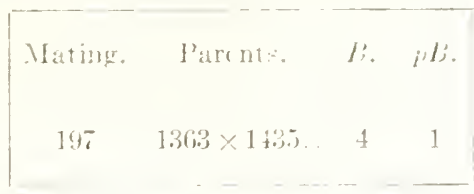

Black $\times$ pirk-eyed black.

Cross 69. Euth parents homozygous. $Y_{2} B_{2} B_{2} D_{2} P_{2} \times Y_{2} B_{2} H_{2} D_{2} p_{2}$. Expectation, all $B_{3}$.

\begin{tabular}{ccc} 
Miating. & l'arents. & B. \\
306 & $1695 \times p 1510 \ldots$ & 16 \\
\hline
\end{tabular}

Cross 70 . Black heterozygous in dark eye crossed with homozygous pink-eyed black. $Y_{2} \mathrm{Br}_{2} \mathrm{~B}_{2} \mathrm{D}_{2} \mathrm{Pp} \times \mathrm{Y}_{2} \mathrm{Br}_{2} \mathrm{~B}_{2} \mathrm{D}_{2} \mathrm{p}_{2}$. Expectation, $1 \mathrm{~B}, 1 \mathrm{pB}$.

\begin{tabular}{|c|c|c|c|}
\hline Mating. & l'arents. & $B$. & $p B$. \\
\hline \multirow[t]{2}{*}{$\begin{array}{l}548 \\
571 \\
220\end{array}$} & 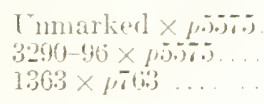 & $\begin{array}{r}13 \\
6 \\
7\end{array}$ & $\begin{array}{l}1 \\
1 \\
5\end{array}$ \\
\hline & & $2 i j$ & 10 \\
\hline
\end{tabular}

Black $\times$ broun.

Cross 71. Both parents homozygous. $Y_{2} B r_{2} B_{2} D_{2} P_{2} \times Y_{2} \mathrm{Br}_{2} D_{2} P_{2}$. Expectation, all $B$.

Niating. Parente B.

Cross 72. Black heterozygous in black crossed with homozygous brown. $\mathrm{Y}_{2} \mathrm{Br}_{2} \mathrm{BD}_{2} \mathrm{P}_{2} \times$ $\mathrm{Y}_{2} \mathrm{Br}_{2} \mathrm{D}_{2} \mathrm{P}_{2}$. Expectation, $1 \mathrm{~B}, 1 \mathrm{Br}$.

\begin{tabular}{|c|c|c|c|}
\hline Mating. & Parents. & $B$. & Br. \\
\hline $\begin{array}{l}306 \\
383 \\
2622 \\
396\end{array}$ & $\begin{array}{l}1631 \times 1050 \ldots . \\
1931 \times 1950 \ldots \\
1931 \times 1919-50 \\
2.523 \times 212.2 \ldots\end{array}$ & $\begin{array}{r}20 \\
10 \\
14\end{array}$ & $\begin{array}{r}1.5 \\
5 \\
5 \\
10\end{array}$ \\
\hline & & 51 & 35 \\
\hline
\end{tabular}

Cross 73. Black, heterozygous in black, dark eye, and the color factor crossed with finkeyed black heterozygous in the color factor and black. $Y \mathrm{Hr}_{2} B D_{2} P p \times \mathrm{IBr}_{2} B D_{2} p_{2}$. Expectation, $9 \mathrm{~B}, 9 \mathrm{pB}, 3 \mathrm{Br}, 3 \mathrm{pBr}, 8 \mathrm{~W}$.

\begin{tabular}{|ccccccc}
\hline Mating. & Parent. & B. & pB. & Br. & pBr. & H. \\
\cline { 3 - 6 } & Unmarked $\times 3306$ & 3 & 2 & 5 & 4 & 9 \\
\hline
\end{tabular}


Black $\times$ pink-eyed brown.

Cross 74. Black heterozygous in dark eye crossed with homozygous pink-eyed brown. $\mathrm{Y}_{2} \mathrm{Br}_{2} \mathrm{~B}_{2} \mathrm{D}_{2} \mathrm{Pp} \times \mathrm{Y}_{2} \mathrm{Br}_{2} \mathrm{D}_{2} \mathrm{p}_{2}$. Expectation, $1 \mathrm{~B}, 1 \mathrm{pB}$.

\begin{tabular}{|c|c|c|c|}
\hline Mating. & Parents. & B. & $p B$. \\
\hline 475 & $p$ immarked $\times 68$. & 1 & 4 \\
\hline
\end{tabular}

Cross 75. Black heterozygous in dark eye and black crossed with homozygous pink-eyed brown. $\mathrm{Y}_{2} \mathrm{Br}_{2} \mathrm{BD}_{2} \mathrm{Pp} \times \mathrm{Y}_{2} \mathrm{Br}_{2} \mathrm{D}_{2} \mathrm{p}_{2}$. Expectation, $1 \mathrm{~B}, 1 \mathrm{pB}, 1 \mathrm{Br}, 1 \mathrm{pBr}$.

\begin{tabular}{|c|c|c|c|c|c|}
\hline Mating. & Parents. & $B$. & $p B$. & $B i$ & $p B r$. \\
\hline 493 & $140 \times 7 \pi .$. & 2 & $\ldots$ & 1 & 2 \\
\hline
\end{tabular}

Black $\times$ pink-eycd dilute brown.

Cross $75 \mathrm{~A}$. Both parents homozygous. $\mathrm{Y}_{2} \mathrm{Br}_{2} \mathrm{~B}_{2} \mathrm{D}_{2} \mathrm{P}_{2} \times \mathrm{Y}_{2} \mathrm{Br}_{2} d_{2} p_{2}$. Expectation, all $\mathrm{B}$.

\begin{tabular}{|c|c|c|}
\hline Mating. & Parents. & $B$. \\
\cline { 2 - 3 } 582 & $7340 \times 7341 \ldots \ldots \ldots \ldots$ & 18 \\
589 & Unmarked $\times$ unmarked... & 4 \\
\hline & & 22 \\
\hline
\end{tabular}

Cross 75в. Black heterozygous in dark eye, crossed with homozygous pink-eyed dilute brown. $\mathrm{Y}_{2} \mathrm{Br}_{3} \mathrm{~B}_{2} \mathrm{D}_{2} \mathrm{Pp} \times \mathrm{Y}_{2} \mathrm{Br}_{2} \mathrm{~d}_{2} \mathrm{p}_{2}$. Expectation, $1 \mathrm{~B}, 1 \mathrm{pB}$.

\begin{tabular}{|c|c|c|c|}
\hline Mating. & Parents. & $B$. & $p B$. \\
\cline { 1 - 3 } 620 & $7472 \times 7475 \ldots$ & 5 & 11 \\
\hline
\end{tabular}

X. Dilute Black, YBrBdP (Fig. 10).

Eyes black; ears, tail, and fect moderately pigmented. Ventral hairs slate-colored. Dorsal hairs are deep blue slate, somewhat washed-out, and at times resembling a very deepcolored dilute black agouti. There is a small tuft of light hairs at the base of the ears. Light yellowish hairs scattered on sides and feet, and around the anus. Unlike the pink-eyed black form next to be deseribed, one would not hesitate in ealling the dilute black animal, black pigmented.

Dilute black $\times$ dilute black.

Cross 76. Both parents homozygous. $Y_{2} \mathrm{Br}_{2} B_{2} d_{2} P_{2} \times Y_{2} \mathrm{Br}_{2} B_{2} d_{2} P_{2}$. Expectation, all $d B$.

\begin{tabular}{|c|c|c|}
\hline Mating. & Parents. & $d B$. \\
\hline \multirow[t]{2}{*}{$\begin{array}{l}549 \\
457 \\
412\end{array}$} & \multirow[t]{2}{*}{$\begin{array}{l}\text { Unmarked } \times 4980 \text {. } \\
4502-03 \times 4497 \ldots \ldots \\
4502 \times 4497 \ldots \ldots\end{array}$} & $\begin{array}{r}15 \\
11 \\
5\end{array}$ \\
\hline & & 30 \\
\hline
\end{tabular}


Cross 77. Both parents heterozygous in the color factor, black and dark eye.

$\mathrm{YBr}_{2} \mathrm{Bd}_{2} \mathrm{Pp} \times \mathrm{YBr}_{2} \mathrm{Bd} \mathrm{d}_{2} \mathrm{Pp}$. Expectation, $2 \mathrm{~T} \mathrm{~dB}, 9 \mathrm{dBr}, 9 \mathrm{pdB}, 3 \mathrm{pdBr}, 1 \mathrm{ij}$.

\begin{tabular}{|c|c|c|c|c|c|c|}
\hline Mating. & Parents. & $d B$ & $\mathrm{ABr}$ & $m B$. & $p d B r$. & 11 . \\
\hline \multirow[t]{2}{*}{$\begin{array}{l}542 \\
511 \\
550\end{array}$} & \multirow[t]{2}{*}{$\begin{array}{l}5698 \times 5699 . \ldots \ldots \\
\text { Lnmarked } \times \text { ummarked. } \\
\text { Lnmarked } \times 5699 \ldots \ldots \ldots\end{array}$} & $\frac{2}{3}$ & $\begin{array}{l}1 \\
1 \\
2\end{array}$ & \begin{tabular}{l}
1 \\
\hdashline
\end{tabular} & $\begin{array}{l}1 \\
1\end{array}$ & $\begin{array}{l}\cdots \\
2\end{array}$ \\
\hline & & 11 & 4 & 5 & 2 & 2 \\
\hline
\end{tabular}

Dilute black $\times$ pink-eyed black.

Cross 78. Dilute black heterozygous in dark eye crossed with homozygous pink-eyed black. $\mathrm{Y}_{2} \mathrm{Br}_{2} \mathrm{~B}_{2} \mathrm{~d}_{2} \mathrm{Pp} \times \mathrm{Y}_{2} \mathrm{Br}_{2} \mathrm{~B}_{2} \mathrm{D}_{2} \mathrm{p}_{2}$. Expectation, $1 \mathrm{~B}, 1 \mathrm{pB}$.

\begin{tabular}{|c|c|c|c|}
\hline Malting. & Parents. & $B$. & $p B$. \\
\hline \multirow{3}{*}{$\begin{array}{l}33 \pi \\
\ldots\end{array}$} & \multirow{3}{*}{ Lnmarked $\times 14049 \times 1+3.5$} & & 3 \\
\hline & & 2 & 1 \\
\hline & & 2 & 4 \\
\hline
\end{tabular}

Cross 79. Dilute black heterozygous in black crossed with pink-eyed black heterozygous in density and black. $\mathrm{Y}_{2} \mathrm{Br}_{2} \mathrm{Bd}_{2} \mathrm{P}_{2} \times \mathrm{I}_{2} \mathrm{Br}_{2} \mathrm{BD} / \mathrm{p}_{2}$. Expectation, $3 \mathrm{~B}, 3 \mathrm{~dB}, 1 \mathrm{Br}, 1 \mathrm{dBr}$.

\begin{tabular}{|cc|ccc|c|}
\hline Mating. & Parents. & B. & Br. & $d B$. & $d B r$ \\
\hline $52 \times$ & $p+520 \times 4523 \ldots$ & 1 & 2 & 2 & $\ldots$ \\
\hline
\end{tabular}

Dilute black $\times$ broun.

Cross 80. Dilute black heterozygous in black, crossed with homozygous brown. $\mathrm{Y}_{2} \mathrm{Br}_{2} \mathrm{Bd}_{2} \mathrm{P}_{2} \times \mathrm{Y}_{2} \mathrm{Br}_{2} \mathrm{D}_{2} \mathrm{P}_{2}$. Expectation, $1 \mathrm{~B}, 1 \mathrm{Br}$.

\begin{tabular}{|ccccc}
\hline Mating. & Parents. & B. & Br. \\
\hline $4+1$ & $2563-61-89 \times 4495$ & 18 & 17 \\
\hline
\end{tabular}

Cross 81. Dilute black heterozygous in black crossed with brown heterozygous in density. $\mathrm{Y}_{2} \mathrm{Br}_{2} \mathrm{Bd}_{2} \mathrm{P}_{2} \times \mathrm{Y}_{2} \mathrm{Br}_{2} \mathrm{DdP}$. Expectation, $1 \mathrm{~B}, 1 \mathrm{Br}, 1 \mathrm{~dB}, 1 \mathrm{dBr}$.

\begin{tabular}{|c|c|c|c|c|c|}
\hline Mating. & Parents. & $B$. & $B r$. & $d B$. & $d B r$. \\
\hline \multirow[t]{2}{*}{$\begin{array}{l}4.51 \\
437\end{array}$} & $\begin{array}{l}4501 \times 48.55 \\
4501 \times 1404 .\end{array}$ & $\begin{array}{l}1 \\
3\end{array}$ & 2 & 1 & 2 \\
\hline & & $t$ & 2 & 1 & 2 \\
\hline
\end{tabular}


Dilute black $\times$ pink-eyed brown.

Cross 82 . Dilute black heterozygous in black erpssed with homozygous pink-eyed brown. $\mathrm{I}_{2} \mathrm{Br}_{2} \mathrm{Bd}_{2} \mathrm{P}_{2} \times \mathrm{Y}_{2} \mathrm{Br}_{2} \mathrm{D}_{2} \mathrm{p}_{2}$. Expeetation, $1 \mathrm{~B}, 1 \mathrm{Br}$.

\begin{tabular}{|c|c|c|c|}
\hline Mating. & Parents. & B. & $B r$. \\
\hline $55 \pi$ & Unmarked $\times p 5806 \ldots \ldots$ & 3 & 2 \\
\hline
\end{tabular}

Cross \$2A. Homozygous dilute black erossed with pink-eyed brown, heterozygous in density. $\quad \mathrm{Y}_{2} \mathrm{Br}_{2} \mathrm{~B}_{2} d_{2} \mathrm{P}_{2} \times \mathrm{Y}_{2} \mathrm{Br}_{2} \mathrm{Dd} p_{2}$. Expectation, $1 \mathrm{~B}, 1 \mathrm{~dB}$.

\begin{tabular}{|c|c|c|c|}
\hline Mating. & Parents. & $B$. & $A B$. \\
& Cnmarked $\times-7 \ldots \ldots$ & 7 & 5 \\
593 & $-8 \times$ unmarker $\ldots . .$. & 1 & 3 \\
\hline 612 & & 8 & 8 \\
\hline
\end{tabular}

Cross 83 . Dilute black heterozygous in dark eye crossed with pink-eyed brown heterozygous in density. $\mathrm{Y}_{2} \mathrm{Br}_{2} \mathrm{~B}_{2} d_{2} P p \times \mathrm{Y}_{2} \mathrm{Br}_{2} \mathrm{Ddp} \mathrm{p}_{2}$. Expectation, $1 \mathrm{~B}, 1 \mathrm{pB}, 1 \mathrm{~dB}, 1 \mathrm{pdB}$.

\begin{tabular}{|c|c|c|c|c|c|}
\hline Mating. & Parents. & B. & $p B$. & $d B$. & $p d B$. \\
\hline 503 & $4078 \times p 4298 \ldots$ & $\ldots$ & 2 & $\ldots$ & 4 \\
\hline
\end{tabular}

XI. P1NK-EYed BLACK, YBrBD (FIg. 11).

Eyes dcep pink; cars very lightly pigmented. Hairs on ventral surface light yellowish-gray.

Tail lightly pigmented. Dorsal hairs varying from a very light yellowish slate color to a deep lilac. The tufts of light hairs back of the ears are present. No appearance of black pigment in the dorsal hairs, to the unaided eye. The nose whiskers are light. almost yellow. The whole appearance resembles somewhat the dark-eyed dilute brown, The feet are slightly pigmented and the hairs around the anus are light.

Pink-eyed black $\times$ pink-eyed black.

Cross 84. Both parents heterozygous in black. $\mathrm{Y}_{2} \mathrm{Br}_{2} \mathrm{BD}_{2} \mathrm{p}_{2} \times \mathrm{Y}_{2} \mathrm{Br}_{2} B \mathrm{D}_{2} \mathrm{p}_{2}$. Expectation, $3 p B, 1 p B r$.

\begin{tabular}{|c|c|c|c|}
\hline Mating. & Parents. & $p B$. & $p B r$ \\
\hline 172 & $p s 45 \times p 763 \ldots \ldots$ & 2 & 2 \\
342 & $p 1812 \times 1764 \ldots \ldots$ & 6 & 1 \\
313 & $1421-1812 \times 1764$. & 10 & 6 \\
& & 18 & 9 \\
\hline
\end{tabular}

Pink-cyed black $\times$ brown.

Cross 85 . Both parents heterozygous in the color factor. $\mathrm{YBr}_{2} \mathrm{~B}_{2} \mathrm{D}_{2} \mathrm{p}_{2} \times \mathrm{YBr}_{2} \mathrm{D}_{2} \mathrm{P}_{2}$. Expectation, $3 B, 1 W$.

\begin{tabular}{|c|c|c|c|}
\hline Mating. & P'arents. & B. & \\
\hline 356 & $2178 \times 2175$. & 4 & \\
\hline
\end{tabular}


Cross 86. Both parents homozygous. $Y_{2} \mathrm{Br}_{2} B_{2} \mathrm{D}_{2} p_{2} \times Y_{2} \mathrm{Br}_{2} D_{2} P_{2}$. Expectation, all $B$.

\begin{tabular}{|c|c|c|}
\hline Mating. & Parents. & $B$. \\
\hline $\begin{array}{l}224 \\
211 \\
230 \\
215 \\
234 \\
270 \\
296 \\
282 \\
281 \\
196 \\
243 \\
236 \\
246 \\
205 \\
381\end{array}$ & $\begin{array}{r}1717 \times 1512 \ldots \ldots \\
1049 \times 1630 \ldots \ldots \\
1042 \times 1630 \ldots \ldots \\
985 \times 1630 \ldots \ldots \\
1638-40 \times 1610 \ldots \\
1721 \times 1609 \ldots \ldots \\
1765 \times 1603 \ldots \ldots \\
1608 \times 1603 \ldots \ldots \\
845 \times 1603 \ldots \ldots \\
\text { Unmarked } \times 1603 \\
1641 \times 1194 \ldots \ldots \\
1520 \times 1194 \ldots \ldots \\
\text { Unmarked } \times 1194 \\
1524 \times 1192 \ldots \ldots \ldots \\
1524 \times 2175 \ldots \ldots\end{array}$ & $\begin{array}{r}13 \\
2 \\
4 \\
14 \\
12 \\
9 \\
3 \\
3 \\
6 \\
7 \\
4 \\
9 \\
14 \\
12 \\
3\end{array}$ \\
\hline & & 115 \\
\hline
\end{tabular}

Cross 87. Pink-eyed black heterozygous in black crossed with homozygous brown.

$\mathrm{Y}_{2} \mathrm{Br}_{2} \mathrm{BD}_{2} \mathrm{p}_{2} \times \mathrm{Y}_{2} \mathrm{Br}_{2} \mathrm{D}_{2} \mathrm{P}_{2}$. Expectation, $\mathrm{I} \mathrm{B}, \mathrm{I} \mathrm{Br}$.

\begin{tabular}{|r|r|r|r|}
\hline Mating. & Parents. & $B$. & $B r$. \\
\hline 274 & Unnmarked $\times 1764 \ldots$ & 3 & 3 \\
258 & $1642 \times 1764 \ldots \ldots \ldots$ & 2 & 5 \\
245 & $572 \times 1394 \ldots \ldots \ldots$ & 2 & 1 \\
266 & $-16 \times 1394 \ldots \ldots \ldots$ & 2 & 3 \\
280 & $1421 \times$ unmarked . . & 2 & 3 \\
& & 11 & 15 \\
\hline
\end{tabular}

Cross 88. Pink-eyed black heterozygous in the color factor and black crossed with brown heterozygous in color factor. $\mathrm{YBr}_{2} \mathrm{BD}_{2} \mathrm{p}_{2} \times \mathrm{YBr}_{2} \mathrm{D}_{2} \mathrm{P}_{2}$. Expectation, $3 \mathrm{~B}, 3 \mathrm{Br}, 2 \mathrm{~W}$.

\begin{tabular}{c|cc|c|c|}
\hline Mating. & Parents. & $B$. & $B r$. & $W$. \\
\hline 269 & $1812 \times 1661 \ldots \ldots$ & 1 & 4 & 2 \\
\hline
\end{tabular}

Cross 89. Pink-eyed black heterozygous in black crossed with brown heterozygous in dark eye. $Y_{2} \mathrm{Br}_{2} \mathrm{BD}_{2} p_{2} \times Y_{2} \mathrm{Br}_{2} \mathrm{D}_{2} \mathrm{Pp}$. Expectation, $1 \mathrm{~B}, 1 \mathrm{pB}, 1 \mathrm{Br}, 1 \mathrm{pBr}$.

\begin{tabular}{|c|c|c|c|c|c|}
\hline Mating. & Parents. & $B$. & $p B$. & $B r$. & $p B r$. \\
\hline 257 & $1714 \times 1526 \ldots$ & 2 & 4 & 2 & 4 \\
\hline
\end{tabular}

Pink-eyed black $\times$ dilute brown.

CRoss $89 \mathrm{~A}$. Both parents homozygous. $Y_{2} \mathrm{Br}_{2} \mathrm{~B}_{2} \mathrm{D}_{2} r_{2} \times \mathrm{Y}_{2} \mathrm{Br}_{2} d_{2} \mathrm{P}_{2}$. Expectation, all $\mathrm{B}$.

\begin{tabular}{|c|c|c|}
\hline Mating. & Parents. & $B$. \\
\hline 648 & Unmarked $\times 318 \ldots$ & 19 \\
\hline
\end{tabular}


Pink-eycd black $\times$ pink-eyed brown.

Cross 90. Both parents homozygous. $Y_{2} \mathrm{Br}_{2} B_{2} D_{2} p_{2} \times Y_{2} \mathrm{Br}_{2} \mathrm{D}_{2} p_{2}$. Expectation, all $p B$.

\begin{tabular}{|c|c|c|}
\hline Mating. & Parents. & $p B$. \\
634 & $7804 \times 7806 \ldots$ & 4 \\
\hline
\end{tabular}

Cross 90A. Pink-eyed black heterozygous in black, crossed with homozygous pink-eyed brown. $\mathrm{Y}_{2} \mathrm{Br}_{2} \mathrm{BD}_{2} \mathrm{p}_{2} \times \mathrm{Y}_{2} \mathrm{Br}_{2} \mathrm{D}_{2} \mathrm{p}_{2}$. Expectation, $1 \mathrm{pB}, 1 \mathrm{pBr}$.

\begin{tabular}{|c|c|c|c|}
\hline Nating. & Parents. & $p B$. & $p B r$. \\
\hline 558 & $5721 \times 5806 \ldots$ & 1 & 2 \\
638 & $7807 \times 7803 \ldots$ & 4 & 5 \\
640 & $7809 \times 7803 \ldots$ & 4 & 5 \\
\hline & & 9 & 12 \\
\hline
\end{tabular}

XiI. Pink-eyed Dilute Black, $\operatorname{YBr} B d p$ (Fig. 12).

Eyes pink; ears, tail and feet extremely lightly pigmented. Coat clearly washed out in appearance, and a real bluish lilac, at times almost silvery. This variety is very characteristic, and is one which, when obtained, is easy to reeognize. No one would, without breeding tests, class this form as possessing black pigment.

\section{Pink-eyed dilute black $\times$ brown.}

Cross 91. Homozygous pink-eyed dilute black crossed with brown, heterozygous in density. $Y_{2} \mathrm{Br}_{2} \mathrm{~B}_{2} d_{2} p_{2} \times Y_{2} \mathrm{Br}_{2} D d P_{2}$. Expectation, $1 \mathrm{~B}, 1 \mathrm{~dB}$.

\begin{tabular}{|rr|r|r|}
\hline Mating. & Parents. & b. & dB. \\
& & & \\
449 & $3627 \times 1404 \ldots$ & 11 & 9 \\
594 & $19 \times 17 \ldots$ & 1 & $t$ \\
\hline & & 12 & 13 \\
\hline
\end{tabular}

Pink-eycd dilute black $\times$ dilute brown.

Cross 91A. Pink-eyed dilute black heterozygous in black erossed with dilute brown heterozygous in dark eye. $Y_{2} \mathrm{Br}_{2} B d_{2} p_{2} \times Y_{2} \mathrm{Br}_{2} d_{2} P p$. Expectation, $1 \mathrm{~dB}, 1 \mathrm{dBr}, 1 \mathrm{pdB}$, $1 p d B r$.

\begin{tabular}{|c|ccc|c|c|}
\hline Mating. & Parents. & $d B$. & $d B r$ & $p d B$. & $p d B r$. \\
\hline 601 & $7162 \times 7461 \ldots$ & 2 & 3 & $\ldots$ & 2 \\
\hline
\end{tabular}


XIII. Brown, $Y B r D P$ (Fig. 13).

Eyes deep brown; ears and tail brown pigmented. Hairs on the ventral surface are lighter than those on the dorsal surface, and are dull dirty brown. Dorsal hairs deep, glossy brown; lighter yellowish hairs occur, as in the black variety, at the base of the ears, scattered on the flanks, sides, and feet, as well as around the anus. The skin is brown pigmented.

Brown $\times$ brown.

Cross 92. One or both parents homozygous. $\mathrm{Y}_{2} \mathrm{Br}_{2} \mathrm{D}_{2} \mathrm{P}_{2} \times \mathrm{Y}_{2} \mathrm{Br}_{2} \mathrm{D}_{2} \mathrm{P}_{2}$. Expectation, only $\mathrm{Br}$.

\begin{tabular}{|c|c|r|}
\hline Mating. & Parents. & $B r$ \\
\hline 348 & Unmarked $\times 2291 \ldots$ & 5 \\
345 & Tnmarked $\times 2386 \ldots$ & 16 \\
525 & $5942 \times 5340 \ldots \ldots \ldots$ & 5 \\
& & 26 \\
& & \\
\hline
\end{tabular}

Cross 93. Both parents heterozygous for the color factor. $\mathrm{YBr}_{2} \mathrm{D}_{2} \mathrm{P}_{2} \times \mathrm{YBr}_{2} \mathrm{D}_{2} \mathrm{P}_{2}$. Expectation, $3 \mathrm{Br}, 1 \mathrm{~W}$.

\begin{tabular}{|ccc|c|}
\hline Mating. & Parents. & Br. & II. \\
\hline 551 & Unmarked $\times 32 \ldots$ & 4 & 2 \\
385 & $2365 \times 2374 \ldots \ldots$ & 1 & 2 \\
504 & $4859 \times 4298 \ldots \ldots$ & 11 & 2 \\
575 & $6225-27 \times 6226 \ldots$ & 11 & 3 \\
\cline { 2 - 4 } & & 30 & 9 \\
\hline
\end{tabular}

Cross 94. Both parents heterozygous in dark eye. $Y_{2} \mathrm{Br}_{2} \mathrm{D}_{2} \mathrm{Pp} \times \mathrm{Y}_{2} \mathrm{Br}_{2} \mathrm{D}_{2} \mathrm{Pp}$. Expectation, $3 \mathrm{Br}, 1 \mathrm{pBr}$.

\begin{tabular}{|c|c|r|r|}
\hline Mating. & Parents. & Bi. & $p B r$. \\
\hline 406 & Unmarked $\times$ ummarked... & 9 & 3 \\
\hline 108 & Unmarked $\times$ immarked.. & 22 & 7 \\
\hline & & 31 & 10 \\
\hline
\end{tabular}

Cross 95. Both parents heterozygous in dark eye and the color factor. $\mathrm{YBr}_{2} \mathrm{D}_{2} \mathrm{Pp} \times$ $\mathrm{YBr}_{2} \mathrm{D}_{2} \mathrm{Pp}$. Expectation, $9 \mathrm{Br}, 3 \mathrm{pBr}, 4 \mathrm{~W}$.

\begin{tabular}{|c|c|c|c|c|}
\hline Mating. & Parents. & $\mathrm{Br}$. & $\mathrm{pBr}$. & $\mathrm{I}$. \\
\hline 408 & Unmarked $\times$ ummarked & 22 & 7 & 2 \\
366 & Unmarked $\times 2392 \ldots \ldots$ & 15 & 4 & 3 \\
\hline & & 37 & 11 & 5 \\
\hline
\end{tabular}


Cross 96. Both parents heterozygous in density and dark eye. $Y_{2} \mathrm{Br}_{2} D d P p \times Y_{2} \mathrm{Br}_{3} D d P p$. Expectation, $9 \mathrm{Br}, 3 \mathrm{dBr}, 3 \mathrm{pBr}, 1 \mathrm{pdBr}$.

\begin{tabular}{|c|c|c|c|c|c|}
\hline Mating. & Parents. & $B r$. & $\mathrm{dBr}$. & $p B r$. & $p d B r$. \\
\hline \multirow{6}{*}{$\begin{array}{l}496 \\
569 \\
521 \\
541 \\
6332 \\
635\end{array}$} & \multirow{6}{*}{ 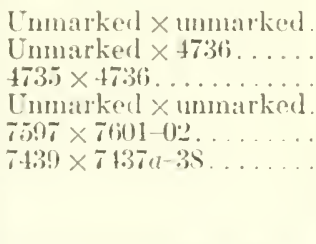 } & 40 & 16 & 2 & 1 \\
\hline & & 3 & 3 & & . \\
\hline & & 6 & 2 & 1 & \\
\hline & & 1.) & 8 & +7 & 1 \\
\hline & & 6 & 4 & 1 & 1 \\
\hline & & 81 & 35 & 8 & 3 \\
\hline
\end{tabular}

Broun $\times$ pink-eyed brown.

Cross 97. Brown heterozygous in density, dark eye and the color factor, crossed with pinkeyed brown heterozygous in density and the color factor. $Y B r_{2} D d P p \times Y B r_{2} D d p_{2}$. Expectation, $9 \mathrm{Br}, 9 \mathrm{pBr}, 3 \mathrm{dBr}, 3 \mathrm{pdBr}, 8 \mathrm{~W}$.

\begin{tabular}{|c|c|ccccc|}
\hline Matting. & Parents. & Br. & dBr. & plir. & $p d B r$. & Wr. \\
$\operatorname{sis}$ & $-35 \times 32 \ldots$ & 3 & $\ldots$ & 1 & 1 & 3 \\
\hline
\end{tabular}

Broun $\times$ pink-eyed dilute broun.

Cross $97_{\mathrm{A}}$. Both parents homozygous. $\mathrm{Y}_{2} \mathrm{Br}_{2} \mathrm{D}_{2} \mathrm{P}_{z} \times \mathrm{Y}_{2} \mathrm{Br}_{2} d_{2} p_{2}$. Expectation, all $\mathrm{Br}$.

\begin{tabular}{|c|c|c|}
\hline Mating. & Parents. & $B r$. \\
\hline $5 \$ 3$ & Unmarked $\times$ ummarked. & 13 \\
\hline
\end{tabular}

Cross 97в. Brown heterozygous in density erossed with homozygous pink-eyed dilute brown. $Y_{2} \mathrm{Br}_{2} \mathrm{DdP} \mathrm{P}_{2} \times \mathrm{Y}_{2} \mathrm{Br}_{2} d_{2} \mathrm{p}_{2}$. Expeetation, $1 \mathrm{Br}, 1 \mathrm{dBr}$.

\begin{tabular}{c|c|c|c|}
\hline Mating. & Parents. & $B r$. & $d B r$. \\
\hline 581 & Unmarked $\times$ unmarked ...... & 3 & 2 \\
\hline
\end{tabular}

XIV. Dilute Brown, YBrdP (Fig. 14).

Eyes brown; ears, tail and feet, as in the dilute brown agouti, are lightly pigmented with brown. Ventral hairs pale fawn. Dorsal hairs dull, washed-out brown, at times resembling a dark, pink-eyed black in general superfieial coloration. Ear tufts barely distinguishable from the rest of the coat. The skin is moderately pigmented with brown.

Dilute brown $\times$ pink-cyed brown.

Cross 98. Both parents homozygous. $Y_{2} \mathrm{Br}_{2} d_{2} P_{2} \times Y_{2} \mathrm{Br}_{2} \mathrm{D}_{2} p_{2}$. Expectation, all $\mathrm{Br}$.

\begin{tabular}{|c|c|c|}
\hline Mating. & Parents. & Br. \\
495 & $4416 \times-77$ & 13 \\
501 & $4859 \times 4298$ & 11 \\
\cline { 3 - 3 } & & 21 \\
\hline
\end{tabular}


Cross 98A. Dilute brown heterozygous in dark eye, crossed with pink-eyed browu heterozygous in density. $Y_{2} \mathrm{Br}_{2} d_{2} \mathrm{Pp} \times \mathrm{Y}_{2} \mathrm{Br}_{2} \mathrm{Dd} \mathrm{p}_{2}$. Expeetation, $1 \mathrm{Br}, 1 \mathrm{dBr}, 1 \mathrm{pBr}, 1 \mathrm{pdBr}$.

\begin{tabular}{|c|c|cc|cc|}
\hline Mating. & Parents. & $\mathrm{Br}$. & $\mathrm{dBr}$. & $\mathrm{plir}$. & $\mathrm{m} / \mathrm{Br}$. \\
\hline $60 \mathrm{~s}$ & $7479 \times 7478 \ldots$ & 3 & 1 & 1 & $\mathrm{~B}$ \\
\hline
\end{tabular}

XV. Pink-Eyed Brown, YBrDp (Fig. 15).

Eyes elear pink. Ears, tail, and feet unpigmented. Hairs on ventral surfaee dull yellowish throughout their length. The yellow hairs at the base of the ears and around the anus are very similar to the rest of the coat, but are, nevertheless, distinguishable from it. The dorsal hairs are rich fawn colored, lighter than the coat of the pink-eyed brown agouti.

$$
\text { Pink-eyed brown } \times \text { pink-eyed brown. }
$$

Cross 99. One or both of the parents homozygous. $\mathrm{Y}_{2} \mathrm{Br}_{2} \mathrm{D}_{2} p_{2} \times \mathrm{Y}_{2} \mathrm{Br}_{2} \mathrm{D}_{2} \mathrm{p}_{2}$. Expectation, only $p B r$.

\begin{tabular}{|c|c|c|}
\hline Mating. & Parents. & $p B r$. \\
\hline 391 & Unmarked $\times 3002$. & 24 \\
\hline 390 & Unmarked $\times 2821$. & 10 \\
\hline 377 & $2799 \times 3002 \ldots \ldots$ & 3 \\
\hline 426 & $3310 \times 3309$. & $\overline{1}$ \\
\hline \multirow[t]{2}{*}{524} & $580.5 \times 5945 \ldots$ & 11 \\
\hline & & 55 \\
\hline
\end{tabular}

Pink-eyed broun $\times$ albino.

(Test matings to determine the gametic constitution of the albinos.)

Cross 100. Pink-eyed brown heterozygous in the eolor factor crossed with an albino, potentially a homozygous brown agouti. $\mathrm{YBr}_{2} \mathrm{D}_{2} \mathrm{p}_{2} \times \mathrm{Br}_{2} \mathrm{D}_{2} \mathrm{P}_{2} \mathrm{~A}_{2}$. Expectation, $1 \mathrm{BrAg}, 1 \mathrm{~W}$

\begin{tabular}{|c|c|c|c|}
\hline Mating. & Parents. & BrAg. & II. \\
\hline 457 & $5245 \times 4984$. & 4 & 6 \\
\hline
\end{tabular}

Cross 101. Pink-eyed brown heterozygous in the color factor, erossed with an albino, potentially a homozygous brown. $\mathrm{YBr}_{2} \mathrm{D}_{2} p_{2} \times \mathrm{Br}_{2} \mathrm{D}_{2} \mathrm{P}_{2}$. Expectation, $1 \mathrm{Br}, 1 \mathrm{~W}$.

\begin{tabular}{|c|c|c|cc|}
\hline Mating. & Parents. & $\mathrm{Br}$. & $\mathrm{Hr}$ & ? \\
\hline 509 & $4082 \times 4286 \ldots$ & 13 & 2 & 4 \\
\hline
\end{tabular}

XVI. Pink-eyed Dilute Brown, YBrdp (Fig. 16).

Eyes elear pink. Very pale pigmentation throughout hairs and skin, a elose approximation to a dirty brownish cream but still preserving the streaky washed-out appearance clearly. This form is as eharaeteristie and easily distinguished as the pink-eyed dilute blaek. The ear tufts are indistinguishable from the rest of the eoat. Pink-eyed dilute browns crossed inter se have given 120 recorded young, all pink-eyed dilute brown.

It must be remembered that all these descriptions of color varieties are intended to be merely as they appear to the unaided eye. Many of the regions here spoken of as pink or unpigmented have, upon microscopic examination, yielded a small amount of pigment. 


\section{RESTRICTED SERIES.}

All animals in this series, that is to say, all yellow animals, are of the zygotic formula $R r$.

The combination $R R$, if formed, fails to develop.

(a) Dark-eyed intense series.

This series eonsists of four types of yellows:

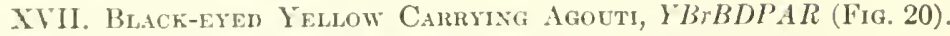

XVIII. Blach-eyed Yellow Without Agouti, YBrBDPR (Fig. 17).

XIX. Brow-ered Yellow Carrying Agouti, YBrDPAR.

XX. Brow-eyed Yhlow Without Agouti, YBrDPR (Fig. 18).

Types XYII and XVII are similar in appearanee, and are indistinguishable save by breeding tests. Types XIX and XX also are only to be distinguished from each other by suitable test matings.

(b) Pink-eyed intense serics.

This scries consists of four types of yellow which are indistinguishable in external appearance:

XXi. I'ixk-eyed Yellow Carrying Black Agouti, y BrBDpAR.

XXII. Pink-eyed Yellow Carring Black, YBrBDpR.

XXili. Pink-eyed Yellow Carrying Brown Agouti, y BrDpAR.

Mitiv. Pink-eyed Yellow Carrytag Brown, yBrDpR.

Test matings are necessary before these forms can be distinguished from each other.

(c) Dark-eyed dilute series.

In this series also there are four types:

XXY. Black-eyed Dilute Yellow Carrying Agouti, YBrbdPAR.

XXVI. Black-eyen Dilute Yellow Wtthout Agouti, YBrBdPR.

XXYil. Brown-eyed Dilute Yellow Carryisg Agouti, Y'BrdPaR.

XXViII. Browe-eyen Dilete Yellow Without Agouti, YBrdPR (Fig. 19).

In this series types XXY and XXVI are distinguishable from types XXYII and XXYIII by a careful examination of the eyes. Such a test, however, is not certain enough to be considered final, and a breeding test forms the only sure basis for a permanent elassification.

(d) Pink-eyed dilute series.

As in the pink-eyed intense series the four forms of this series are indistinguishable save by breeding tests. This is because of the fact that the total amount of pigment in the eye is so small that it is impossible to determine whether it is brown or black by anything short of a microscopir examination. The gametic formula follow:

XAix. Pink-eyen Dilete Yellow Carrying Black Agouti, yBrBdpaR.

Axx. Pink-eyeid Dilute Yellow Cambing Black, ÝbrbdpR.

XXXi. Pink-eyed Dilute Yellow Caminisg Brown Agouti, YBrdpaR.

XXXil, Pink-eyed Dilete lilliow Carrying Brown, YBrdpr.

Each of these series may now be eonsitered separately.

$\mathrm{Up}_{\mathrm{p}}$ to a certain point there were no pink-eyed or dilute mice, yellow or non-yellow in my stock. All the yellows were therefore intense dark-eyed yellows and would group themselves under one of the first four types (XVII, XVIII, XIX, or XX). To test them a cross with any type of brown animal lacking the agouli factor would suffice.

A list of such crosses follows. Yellows which proved to be of type XVII are ineluded in the folluwing table: 


\begin{tabular}{|c|c|c|c|c|}
\hline liating. & Parents. & $i$ & $B . i g$ & $\begin{array}{l}\text { \%yonice formula } \\
\text { of yollow parest. }\end{array}$ \\
\hline $\begin{array}{l}29 \\
34 \\
36\end{array}$ & $\begin{array}{l}700-702 \text { l.r. } \times 505 \text { yed } \\
707 \text { br. } \times 502.41 \text { yel. } \\
5(12.2 .1 \text { yel. } \times \text { br } \ldots \ldots\end{array}$ & $\begin{array}{l}2 \\
6 \\
1\end{array}$ & $\begin{array}{l}5 \\
2 \\
3\end{array}$ & 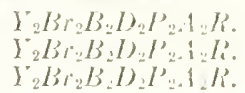 \\
\hline & & 9 & 10 & \\
\hline
\end{tabular}

All these yellows seem to have been homozygous in the factors for black and for agouti Yellows of type XIX folluw:

\begin{tabular}{|c|c|c|c|c|c|}
\hline Mating. & Parents. & $Y$. & BrAg. & $\mathrm{Br}$. & $\begin{array}{l}\text { 7ygotic formula } \\
\text { of yellow parent. }\end{array}$ \\
\hline \multirow[t]{2}{*}{$\begin{array}{l}15-111-85 \\
18-19 \\
56 \\
82\end{array}$} & \multirow[t]{2}{*}{$\begin{array}{l}140 \text { yel. } \times \text { brown } \\
\text { br. } \times 5 \text { y yel.... } \\
\text { br. } \times 1 \text { is yel } \\
502.11 \text { yet. } \times \text { br. }\end{array}$} & $\begin{array}{r}12 \\
1 \\
2 \\
2\end{array}$ & $\begin{array}{l}\$ \\
5 \\
1 \\
3\end{array}$ & $\begin{array}{l}1 \\
\cdots \\
2\end{array}$ & \multirow[t]{2}{*}{ 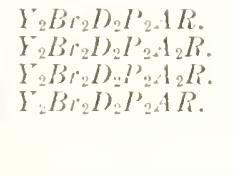 } \\
\hline & & 17 & 17 & 3 & \\
\hline
\end{tabular}

There are two types of zygotes here, those homozygous in the agouti pattern $(A)$ and those heterozygous, the latter giving non-agouti, as well as agouti young.

The yellows of type XVIII are also of two sorts, those homozygous in the factor for the production of black $(B)$ and those heterozygous in this factor. Thus in the following table 502.21A yollow is known to be an animal homozyous in the factor $B$, while all the other yellow animals are heterozygous, producing browns as well as blacks.

\begin{tabular}{|c|c|c|c|c|c|}
\hline Matingr. & l'arents. & $I$. & $B$. & $B r$. & $\begin{array}{l}\text { \%yotic formula } \\
\text { of yellow parent. }\end{array}$ \\
\hline $\begin{array}{r}03 \\
11 \\
37 \\
112 \\
10(1) \\
320\end{array}$ & 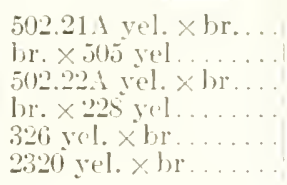 & $\begin{array}{l}2 \\
1 \\
1 \\
1 \\
1 \\
4\end{array}$ & $\begin{array}{l}1 \\
1 \\
2 \\
2 \\
1 \\
1 \\
2\end{array}$ & $\begin{array}{l}1 \\
2 \\
1 \\
1 \\
1 \\
1\end{array}$ & $\begin{array}{l}Y_{2} B r_{2} B_{2} D_{2} P_{2} R \\
Y_{2} B r_{2} L D D_{2} I_{2} R \\
Y_{2} B r_{2} B D D_{2} I_{2} R \\
Y_{2} B r_{2} B D_{2} I_{2} R \\
Y_{2} B r_{2} B D_{2} P_{2} R \\
Y_{2} B r_{2} B D D_{2} P_{2} R .\end{array}$ \\
\hline & & 10 & 9 & 6 & \\
\hline
\end{tabular}

Type XX, yellows which give browns only, are seen in the following table:

$$
\text { Yellow } \times \text { broun. }
$$

\begin{tabular}{|c|c|c|c|c|}
\hline Mating. & Parents. & $Y$. & Br. & $\begin{array}{l}\text { Zygotic formula } \\
\text { of yellow parent. }\end{array}$ \\
\hline $\begin{array}{c}62 \\
232 \\
293 \\
329 \\
331 \\
304-314 \\
327-222 \\
141-142 \\
151-170 \\
597 \\
601 \\
602\end{array}$ & 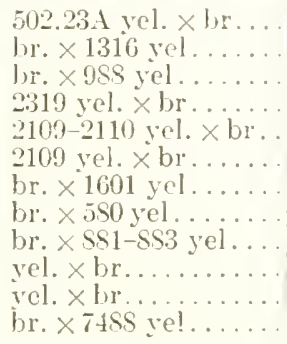 & $\begin{array}{r}2 \\
1 \\
3 \\
3 \\
1 \\
13 \\
5 \\
11 \\
4 \\
6 \\
6 \\
6 \\
1\end{array}$ & $\begin{array}{l}1 \\
7 \\
2 \\
4 \\
7 \\
3 \\
4 \\
5 \\
9 \\
1 \\
3 \\
6\end{array}$ & 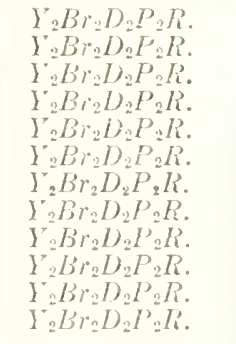 \\
\hline & & 56 & 49 & \\
\hline
\end{tabular}


It laas been shown, then, that yellows of the four dark-eyed intense pigmented types exist.

The pink-eyed yellows (types XXI-XXIV inelusive) have been crossed only inter se or with black pigmented forms, but it is certain that they also can oceur in the four types comparable to the dark-eyed intense series.

The dark-eyed dilute yellows have been erossed with brown only in a few eases. Chiefly they have been bred inter se to determine whether the $2: 1$ ratio holds good in their case as in the intense forms. Of those tested, one, 97298 , is of the zygotic formula $Y_{2} B_{2} B d_{2} P p A_{2} R$ and when crossed with a pink-eyed brown has given 1 yel, 1 pdyel, $1 B A g, 2 B r A g, 1 p B A g$. This shows that types XXV and XXVII ean exist. The other animal, also a female, gave by a pink-eyed brown male, 7 yel, 2 pyel, $2 \mathrm{Blk}, 2 \mathrm{Br}$, $3 \mathrm{pB}$. This animal was of the formula $\mathrm{Y}_{2} \mathrm{Br}_{2} B d_{2} P \mathrm{P}$, and argues strongly in favor of the existence of types XXVI and XXVIII.

Of the pink-eyed dilute yellows few have been tested, but I have, at present, a race of animals which give only two sorts of young, viz, pink-eyed dilute yellows and pink-eyed dilute browns; such pink-eyed dilute yellows are the ultimate recessives of the yellow series belonging to type XXXlI, formula $Y_{2} B r_{2} d_{2} p_{2} R$.

From the few matings given above, together with the larger number of yellow matings which follow, it is easy to see that yellows may be obtained of the various zygotic compositions found in the non-yellow varieties, differing from them only by the addition of the restriction factor, $R$.

We shall first consiler the crosses between yellow animals of these four varieties, which form the intense dark-eyed series.

Yellon' $\times$ yellow, giving only dark-cyed intense young.

C'moss 102. Giving $Y$ and $B r$.

\begin{tabular}{|c|c|c|c|}
\hline . Matting. & Parents. & $I^{\prime}$. & $B r$. \\
\hline 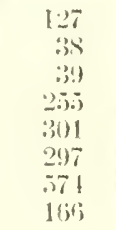 & 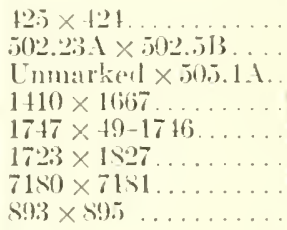 & $\begin{array}{r}1 \\
5 \\
1 \\
3 \\
6 \\
12\end{array}$ & $\begin{array}{l}3 \\
3 \\
3 \\
1 \\
1 \\
2 \\
1 \\
1 \\
7\end{array}$ \\
\hline & & $3 i$ & 21 \\
\hline
\end{tabular}

Cross 103. Giving $Y, B r$, and $W^{r}$ (and in one case Br.lg).

\begin{tabular}{|c|c|c|c|c|c|}
\hline Mating. & Parents. & $Y$. & Brag. & $B r$. & $W$. \\
\hline $\begin{array}{l}384 \\
118 \\
145 \\
175 \\
185 \\
183 \\
320 \\
352\end{array}$ & 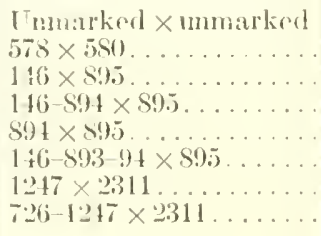 & $\begin{array}{r}22 \\
3 \\
5 \\
3 \\
1 \\
3 \\
3 \\
5 \\
3\end{array}$ & $\begin{array}{l}1 \\
\ldots \\
\cdots \\
\ldots\end{array}$ & $\begin{array}{l}7 \\
1 \\
1 \\
5 \\
5 \\
i \\
1 \\
1\end{array}$ & $\begin{array}{l}6 \\
1 \\
7\end{array}$ \\
\hline & & 46 & 1 & 26 & 18 \\
\hline
\end{tabular}


Cross 104. Giving $Y, B A g, B$, and $W$.

\begin{tabular}{|c|c|c|c|c|c|}
\hline Mating. & Parents. & $Y$. & $B A g$. & B. & W. \\
\hline$s$ & $502.1 \mathrm{~A} \times 502.5 \mathrm{~A}$ & 3 & & & 3 \\
\hline 9 & $502.2 \Lambda \times 502.5 \Lambda$ & 10 & 2 & 1 & 3 \\
\hline 10 & $502 \times 511 \ldots \ldots$ & 7 & & & 2 \\
\hline 15 & $509 \times 511 \ldots$ & 2 & 2 & & 1 \\
\hline 245 & $1247 \times 1316 \ldots \ldots$ & 5 & . & & 3 \\
\hline \multirow[t]{2}{*}{570} & \multirow[t]{2}{*}{ Unmurked $\times 3297$. } & 2 & . & $\therefore$ & 1 \\
\hline & & 29 & 4 & 1 & 13 \\
\hline
\end{tabular}

Cross 105. Miscellaneous yellows giving $Y, B A g$, and $B$.

\begin{tabular}{|c|c|c|c|c|c|}
\hline Mating. & Parents. & $Y$. & $B A g$. & b. & $B A g$ or $B$. \\
\hline \multirow{9}{*}{$\begin{array}{r}529 \\
283 \\
264 \\
27 \\
14 \\
7 \\
22 \\
29\end{array}$} & \multirow{9}{*}{$\begin{array}{l}\text { Unmarked } \times 193 \mathrm{~s} . \\
1723 \times \text { unmarked } \\
1666 \times 1667 \ldots \ldots \\
509.1 \mathrm{~A} \times 511 \ldots \ldots \\
509 \times 510 \ldots \ldots \\
502 \times 503 \ldots \\
514.6 \mathrm{~A} \times 505.1 \mathrm{~A} \ldots \\
514.4 \mathrm{~A} \times 505.1 \mathrm{~A} \ldots\end{array}$} & 38 & 1 & 11 & 4 \\
\hline & & & & 1 & $\ldots$ \\
\hline & & $i$ & & & . \\
\hline & & 3 & 1 & . & . \\
\hline & & 3 & 1 & & $\ldots$ \\
\hline & & 5 & & & \\
\hline & & 1 & . & $\ldots$ & .. \\
\hline & & 4 & & & \\
\hline & & 55 & 3 & 12 & $t$ \\
\hline
\end{tabular}

Sooly yellow $\times$ sooty yellow, giving only dark-eyed intense young.

Cross 106. Giving $Y, s Y, B$, and $B, 1 g$.

\begin{tabular}{|c|c|c|c|c|c|c|}
\hline Mating. & Parents. & $Y$. & $s Y$. & $B A g$. & B. & $B$ or $B A g$. \\
\hline \multirow[t]{2}{*}{$\begin{array}{l}440 \\
471 \\
502\end{array}$} & \multirow[t]{2}{*}{$\begin{array}{l}3196 \times 3777 \\
\text { Unmarked } \times 3957 \\
\text { Unmarked } \times 3777\end{array}$} & $\begin{array}{r}3 \\
1 \\
15\end{array}$ & $\begin{array}{r}1 \\
8 \\
13\end{array}$ & $\begin{array}{l}3 \\
4\end{array}$ & 10 & 1 \\
\hline & & 19 & 22 & 7 & 12 & 1 \\
\hline
\end{tabular}

Cream $\times$ cream, giving nothing but durk-eyed intense young.

Cross 107. Giving eream, or light yellow, $B$ and $B r$.

\begin{tabular}{|c|c|c|c|c|}
\hline Mating. & Parents. & Crcam $Y$. & $B$. & $B r$ \\
\hline 284 & $1248 \times 1414 \ldots$ & 4 & $\ddots$ & $\ddots$ \\
445 & $3907 \times 875 \ldots \ldots$ & 2 & 1 & 2 \\
122 & $648 \times 647 \ldots \ldots$ & $\ddots$ & 2 & $\because$ \\
285 & $1750 \times 1745-16$. & 2 & $\cdots$ & 2 \\
\hline & & $S$ & 3 & 4 \\
\hline
\end{tabular}


Cross 108. Giving eream, $B A g, B, B r$, and $W$.

\begin{tabular}{|c|c|c|c|c|c|c|}
\hline Mating. & Parents. & Cream $Y$. & $B A g$. & B. & $\mathrm{Br}$. & $\mathrm{W}$. \\
\hline \multirow[t]{2}{*}{$\begin{array}{l}397 \\
469 \\
325 \\
185 \\
415\end{array}$} & $\begin{array}{l}3905 \times 855 \ldots \ldots \ldots \\
4068 \times 4796 \ldots \ldots \ldots \\
2050 \times 575 \ldots \ldots \ldots \\
1248 \times 580 \ldots \ldots \\
\text { Inmarked } \times 875 \ldots\end{array}$ & $\begin{array}{l}4 \\
\frac{1}{7} \\
3 \\
3\end{array}$ & $\begin{array}{l}2 \\
1 \\
\cdots \\
\cdots\end{array}$ & $\begin{array}{l}2 \\
\dddot{2} \\
\ddot{2}\end{array}$ & $\begin{array}{l}\cdots \\
4 \\
1 \\
2\end{array}$ & $\begin{array}{l}1 \\
1 \\
1 \\
1 \\
1\end{array}$ \\
\hline & & 15 & 3 & 6 & 7 & 5 \\
\hline
\end{tabular}

Ycllow $\times$ eream, giving nothing but dark-eyed intense young.

Cross 109. Giving $Y, l, B r A g$, and $B r$.

\begin{tabular}{|c|c|c|c|c|c|}
\hline Mating. & Parents. & $Y$. & $B$. & $B r A g$. & $B r$. \\
\hline \multirow[t]{2}{*}{$\begin{array}{l}450 \\
233\end{array}$} & \multirow[t]{2}{*}{$\begin{array}{l}\text { Inminked } \times 3906 . \\
882 \times 601 \ldots \ldots \ldots .\end{array}$} & $\begin{array}{r}36 \\
1\end{array}$ & $\begin{array}{l}10 \\
\cdots\end{array}$ & 3 & $\begin{array}{l}5 \\
1\end{array}$ \\
\hline & & 37 & 10 & 3 & 6 \\
\hline
\end{tabular}

Cross 110. Giving $Y, B, B r A g, B r$ ?, and $W$.

\begin{tabular}{|c|c|c|c|c|c|c|}
\hline Mating. & Parents. & I. & $B$. & $\operatorname{BrAg} g$. & $B$ or $B r$. & $W^{\prime}$. \\
\hline \multirow[t]{2}{*}{$\begin{array}{l}273 \\
272\end{array}$} & \multirow[t]{2}{*}{$\begin{array}{l}2049 \times 875 \\
20.4 \times 875\end{array}$} & $\begin{array}{l}5 \\
4\end{array}$ & 1 & I & $\begin{array}{c}1 \\
\ldots\end{array}$ & 4 \\
\hline & & 9 & 1 & 1 & 1 & 4 \\
\hline
\end{tabular}

Cross 111. Giving $Y$, cream, $B, B r$, and $W^{r}$.

\begin{tabular}{|c|c|c|c|c|c|c|}
\hline Mating. & Parents. & $Y$. & Cream $Y$. & $B$. & $B r$. & $\mathrm{H}$. \\
\hline \multirow[t]{2}{*}{$\begin{array}{l}145 \\
123 \\
15 !\end{array}$} & \multirow[t]{2}{*}{$\begin{array}{l}284 \times 875 \\
281 \times 617 \\
8 \$ 2 \times 881 .\end{array}$} & 10 & $\begin{array}{l}5 \\
5 \\
2\end{array}$ & $\begin{array}{l}2 \\
1 \\
1\end{array}$ & $\begin{array}{l}3 \\
8\end{array}$ & 3 \\
\hline & & 11 & 12 & 4 & 11 & 3 \\
\hline
\end{tabular}

Yellow $\times$ yellow, giring intense and dilute durk-cyed young.

Cross 112. Giving $Y, B A g, B r A g, B r, d Y, d B A g$.

\begin{tabular}{|c|c|c|c|c|c|c|c|}
\hline Mating. & Parents. & $Y$. & $d Y$. & $B A g$. & $d B A g$. & BrAg. & $B r$. \\
\hline \multirow[t]{2}{*}{$\begin{array}{l}361 \\
250\end{array}$} & \multirow[t]{2}{*}{$\begin{array}{r}620 \times 621 \\
165 \% \times 1660\end{array}$} & (i) & 3 & $\begin{array}{l}2 \\
\therefore\end{array}$ & $\begin{array}{l}1 \\
\ldots\end{array}$ & $\begin{array}{l}1 \\
\ldots\end{array}$ & 1 \\
\hline & & 12 & 3 & 2 & 1 & 1 & 1 \\
\hline
\end{tabular}


Cross 113. Giving $Y, b i g$, albig, and $14^{\circ}$.

\begin{tabular}{|cccccc}
\hline Mating. & Parenti. & i. & B.1\% & HSilg. & W. \\
\hline 23 & $530 \times 511 \ldots$ & 5 & 3 & 1 & 5 \\
\hline
\end{tabular}

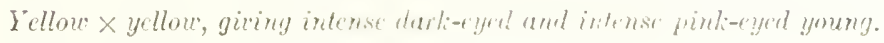

Cross 114. Giving $Y, p Y, B, p l$, Br, and $p B r$.

\begin{tabular}{|c|c|c|c|c|c|c|c|}
\hline Mating. & Parmits. & $i$ & p) 5 & b. & bir. & plis. & plir. \\
\hline 321 & $2198 \times 2197$ & 7 & & $\bar{j}$ & 2 & 2 & \\
\hline 311 & $1947 \times 1577 \ldots \ldots \ldots \ldots$ & t & 2 & lj & . & $\ddot{2}$ & 1 \\
\hline \multirow[t]{2}{*}{393} & Unmarked $\times$ unmirked. & 3 & 2 & 1 & $\cdots$ & . & \\
\hline & & 14 & 4 & 12 & $\ddot{2}$ & -1 & 1 \\
\hline
\end{tabular}

Cross 114. Giving $Y, s Y, p Y^{*}, B d g, B, B r A g, B r, p L A g, p B$, pBr, and $p l$.

\begin{tabular}{|c|c|c|c|c|c|c|c|c|c|c|c|c|}
\hline Mating. & Parents. & $Y$ & $s Y$. & $\mu Y$ & $B A y$ & $B$ & Br.1g. & Er. & pliso. & $p B$. & plir. & $p ?$ \\
\hline $\begin{array}{l}477 \\
459 \\
256 \\
244 \\
257\end{array}$ & $\begin{array}{l}\text { Unmarked } \times 5226 \ldots \\
\text { Unmarked } \times 4631 \ldots \\
1722 \times 1527 \ldots \ldots \ldots \\
1724 \times 1527 . \ldots \ldots \\
1722-24 \times 1527 \ldots \ldots\end{array}$ & $\begin{array}{l}45 \\
7 \\
7 \\
4 \\
4\end{array}$ & $\begin{array}{l}3 \\
1 \\
1 \\
1 \\
\cdots\end{array}$ & $\begin{array}{l}2 \\
2 \\
2 \\
2 \\
\vdots \\
2 \\
2\end{array}$ & $\begin{array}{c}11 \\
\ldots \\
\ldots\end{array}$ & $\begin{array}{l}11 \\
\because \\
1 \\
2\end{array}$ & $\begin{array}{l}4 \\
\ldots \\
\ldots \\
\ldots\end{array}$ & $\begin{array}{l}6 \\
1 \\
\because\end{array}$ & $\begin{array}{l}1 \\
\cdots \\
\cdots \\
\cdots\end{array}$ & $\begin{array}{l}\cdots \\
\cdots \\
\ddot{3}\end{array}$ & $\begin{array}{l}1 \\
\cdots \\
\cdots \\
\cdots \\
\cdots\end{array}$ & $\ddot{1}$ \\
\hline & & 67 & 6 & 13 & 11 & 16 & 4 & 9 & 1 & 3 & 1 & 1 \\
\hline
\end{tabular}

Cross 115. Giving $Y, p Y, B A g, B r A g, B, B r, p B$, and $W^{r}$.

\begin{tabular}{|c|c|c|c|c|c|c|c|c|c|}
\hline Mating. & Parents. & $Y$. & $p Y$. & $B .1 g$. & Bralg. & $b$. & Br. & $i B$. & 11. \\
\hline \multirow{3}{*}{$\begin{array}{l}430 \\
159\end{array}$} & $3299 \times 3297$. & $j$ & 1 & & & 4 & & 1 & 3 \\
\hline & $786 \times 751$ & 4 & 1 & 1 & 2 & & 1 & & 1 \\
\hline & & 9 & 2 & 1 & 2 & $t$ & 1 & 1 & 4 \\
\hline
\end{tabular}

Sooty yellow $\times$ yellow, gieing intense dorti-eyerl and intchse ginti-ezed young.

Ciross 116.

\begin{tabular}{|c|c|c|c|c|c|c|c|c|c|c|c|}
\hline Mating. & Parents. & $Y$ & $S Y$. & $p Y$. & $B: 1 g$ & Bi.1g. & $B$ & $B r$ B & $p B .1 g$ & $p B$. & $p B r$ \\
\hline 251 & $1826 \times 1529$ & 2 & & 1 & . & $\ldots$ & 1 & 1 & & & \\
\hline 240 & $1828 \times 1829 \ldots$ & 5 & 1 & 4 & $\cdots$ & $\because$ & 1 & 1 & $\ddot{1}$ & $\because$ & $\begin{array}{l}\cdots \\
\cdots\end{array}$ \\
\hline 275 & $1826-25 \times 1529$. & 3 & & 3 & $\ldots$ & $\cdots$ & & & $\ldots$ & 1 & $\cdots$ \\
\hline 325 & $2666-67 \times 1829$ & i & 1 & & & & 2 & 3 & . & & $\ldots$ \\
\hline 362 & $2666 \times 1529 \ldots \ldots$ & 1 & 1 & & . & & 1 & 1 & . & 1 & \\
\hline 367 & Unmarked $\times 1829$. & 3.5 & 11) & 13 & . & & $1 S$ & 5 & & 6 & 1 \\
\hline 339 & $2665 \times 1529 \ldots \ldots \ldots \ldots$ & 6 & & & . & . & & 1 & . & . & . \\
\hline 353 & $2667 \times 1829 \ldots \ldots \ldots \ldots$ & 1 & . & & . & & 1 & 1 & . & . & . \\
\hline 354 & $2665 \times 1829 \ldots \ldots \ldots \ldots$ & 5 & $\ddot{2}$ & & . & & 3 & 2 & & . & . \\
\hline 460 & Unmarked x unmarkred. & 4 & & . & . & & 2 & . & 1 & . & . \\
\hline 415 & Unmarked $\times 3160 \ldots \ldots$ & 10 & 3 & 1 & . & & & . & . & . & . \\
\hline 411 & Unmarked $\times 3640 \ldots \ldots$ & 3 & 1 & & $\cdots$ & & $\cdots$ & . & . & . & . \\
\hline 485 & Unmarked $\times 3777 \ldots \ldots$ & 4 & 1 & & 1 & & 3 & $\cdots$ & . & . & $\ldots$ \\
\hline \multirow[t]{2}{*}{472} & Unmarked $\times 3957 \ldots \ldots$ & 24 & 9 & & 14 & 6 & 2 & 2 & $\ldots$ & $\ldots$ & $\cdots$ \\
\hline & & 112 & 32 & 22 & 1.5 & 6 & 34 & 17 & 2 & 10 & 1 \\
\hline
\end{tabular}


Yellow $\times$ yellow, giving intense and dilute dark-eyed and pink-eyed young.

Cross 117 .

\begin{tabular}{|c|c|c|c|c|c|c|c|c|c|c|}
\hline Mating. & Parents. & $Y$. & $p Y$. & $B A g$. & $d B A g$. & $p B A g$. & $p d B A g$. & $p d B$. & $p d B r$. & IV. \\
\hline 446 & Unmarked $\times 4051 .$. & 6 & 2 & 2 & 2 & 1 & 1 & 1 & 1 & 1 \\
\hline
\end{tabular}

Yellow $\times$ yellow, misecllaneous.

Cross 118. No color varieties recorded.

\begin{tabular}{|c|c|c|c|c|}
\hline Mating. & Parents. & $Y$. & non $Y$. & $W$. \\
\hline $\begin{array}{l}556 \\
555 \\
579 \\
544 \\
568 \\
543 \\
565 \\
572\end{array}$ & $\begin{array}{l}\text { Unmarked } \times 4331 \ldots \ldots \\
\text { Unmarked } \times 4523 \ldots \ldots \\
\text { Unmarked } \times 4631 \ldots \ldots \ldots \\
\text { Unmarked } \times 4712 \ldots \ldots \ldots \\
\text { Unmarked } \times 4891 \ldots \ldots \ldots \\
\text { Unmarked } \times 4905 \ldots \ldots \ldots \\
\text { Unmarked } \times 4149 \ldots \ldots \ldots \\
\text { Unmarked } \times \text { unmarked. }\end{array}$ & $\begin{array}{r}4 \\
9 \\
11 \\
5 \\
5 \\
2 \\
3 \\
77\end{array}$ & $\begin{array}{r}2 \\
3 \\
9 \\
\ddot{2} \\
4 \\
\ddot{3} \\
\ddot{3}\end{array}$ & $\begin{array}{l}. \\
\because \\
\therefore \\
\therefore \\
\therefore \\
2\end{array}$ \\
\hline & & 116 & 58 & 2 \\
\hline
\end{tabular}

Iellow $\times$ dilute yellow, giving nothing but intense dark-eyed young.

Cross 119. Giving $Y, B A g$ ? $B, B r A g$, and $B r$.

\begin{tabular}{|c|c|c|c|c|c|c|}
\hline Mating. & Parents. & $Y$. & $B A g$ or $B$. & $B$. & $B r A g$. & $B r$. \\
\hline \multirow[t]{2}{*}{$\begin{array}{l}546 \\
564 \\
520\end{array}$} & \multirow[t]{2}{*}{$\begin{array}{l}\text { Unmarked } \times 5155 \text {. } \\
\text { Unmarked } \times 4710 \text {. } \\
\text { Unmarked } \times 4334\end{array}$} & $\begin{array}{r}14 \\
2 \\
1\end{array}$ & $\begin{array}{l}1 \\
\cdots \\
\cdots\end{array}$ & $\begin{array}{l}2 \\
\cdots \\
\cdots\end{array}$ & $\begin{array}{l}3 \\
.\end{array}$ & $\begin{array}{l}2 \\
\ddot{1}\end{array}$ \\
\hline & & 17 & 1 & 2 & 3 & 3 \\
\hline
\end{tabular}

Yellow $\times$ dilute yellow, giving intense and dilute dark-eycd young.

Cross 120. Giving $Y, d Y, d B A g, B r A g$, and $d B r A g$.

\begin{tabular}{|c|c|c|c|c|c|c|}
\hline Mating. & Parents. & $Y$. & $d Y$ & $d B A g$. & $B r A g$. & $d B r A g$. \\
\hline \multirow[t]{2}{*}{$\begin{array}{l}567 \\
566 \\
553\end{array}$} & \multirow[t]{2}{*}{$\begin{array}{l}\text { Unmarked } \times 4146 \ldots \\
\text { Unmarked } \times 4712 . \\
\text { Unmarked } \times 4905 .\end{array}$} & $\begin{array}{l}2 \\
6 \\
2\end{array}$ & $\begin{array}{l}\cdots \\
\because 6\end{array}$ & $\ddot{1}$ & 1 & $\begin{array}{l}1 \\
1 \\
1\end{array}$ \\
\hline & & 10 & 6 & 1 & 1 & 3 \\
\hline
\end{tabular}

Yellow $\times$ dilute yellow, giving only intense dark-eycd and pink-eyed young.

Cross 121. Giving $Y, p Y, B A g, B r A g, B$, and $W$.

\begin{tabular}{|c|c|c|c|c|c|c|c|}
\hline Mating. & Parents. & $Y$. & $p Y$. & $B A g$. & $B r A g$. & $B$. & $W$. \\
\hline 476 & Unmarked $\times 4710 \ldots$ & 10 & 1 & 2 & 2 & 1 & 1 \\
\hline
\end{tabular}


Yellow $\times$ dilute yellow, giving intense and dilute derk-eyed and pink-cyed young.

Choss 122. Giving $Y, p Y, d Y, p d Y, B A g, d B r A g, d B$, or $d B A g$.

\begin{tabular}{|c|c|c|c|c|c|c|c|c|}
\hline Mating. & Parents. & $Y$. & $d Y$. & $p Y$. & $p d Y$. & $B .19$. & dBrAg. & $A B$ or $d B A g$. \\
\hline \multirow[t]{2}{*}{$\begin{array}{l}563 \\
533\end{array}$} & \multirow[t]{2}{*}{$\begin{array}{l}\text { Unmarked } \times 4631 \\
\text { Unmarked } \times 5008 .\end{array}$} & $\begin{array}{r}1 \\
11\end{array}$ & $\begin{array}{l}1 \\
5\end{array}$ & 1 & $\begin{array}{l}1 \\
. .\end{array}$ & 1 & $\begin{array}{l}1 \\
. .\end{array}$ & 2 \\
\hline & & 12 & 6 & 1 & 1 & 1 & 1 & 2 \\
\hline
\end{tabular}

Y'cllow $\times$ ditule sooty yellow, giving intense and ditute dark-cyed young.

Cross 123. Giving $Y, s Y, d Y, d s Y, B A g, B r A g, d B A g$, and $d B r A g$.

\begin{tabular}{|c|c|c|c|c|c|c|c|c|c|c|}
\hline Mating. & Parents. & $Y$. & $s Y$. & $d \mathrm{~S}$. & $d s Y$. & $B i g$. & $B r A g$. & $B A g$ or $B r A g$. & $d B A g$. & $d B r A g$. \\
\hline \multirow{2}{*}{$\begin{array}{l}463 \\
514\end{array}$} & $\begin{array}{l}\text { Unmarked } \times 4346 \text {. } \\
\text { Unmarked } \times 2348 \text {. }\end{array}$ & 9 & 2 & 1 & 3 & $\begin{array}{c}6 \\
2\end{array}$ & 4 & 3 & 1 & 1 \\
\hline & & 14 & 3 & 6 & 7 & $\delta$ & 5 & 3 & 2 & 1 \\
\hline
\end{tabular}

Yellow $\times$ pink-cyed yellow, giving only intensc tark-eyed young.

Cross 124. Giving $Y$ and $B A g$.

\begin{tabular}{|c|c|c|c|}
\hline Mating. & Parents. & $Y$. & $B A g$. \\
\hline \multirow[t]{2}{*}{$\begin{array}{r}554 \\
99\end{array}$} & $\begin{array}{l}\text { Unmarked } \times 4149 \ldots \ldots \\
227 \times 413 \ldots \ldots \ldots \ldots\end{array}$ & $\begin{array}{l}3 \\
4\end{array}$ & 1 \\
\hline & & 7 & 1 \\
\hline
\end{tabular}

Yellow $\times$ pink-eyed yellow, giting intense and dilute dark-eyed young.

Cross 125. Giving $Y, B$, and $d B$.

\begin{tabular}{|c|c|c|c|c|}
\hline Mating. & Parents. & $Y$. & $B$. & $d B$. \\
\hline 125 & $326 \times 563 \ldots$ & 4 & 1 & 2 \\
\hline
\end{tabular}

Yellow $\times$ pink-eyed yellow, giving intense pink-eyed and dark-cyed young.

Cross 126. Giving $Y, p Y, B$ or $B A g, B, B r, p B r A g$, and $p B$.

\begin{tabular}{|c|c|c|c|c|c|c|c|c|c|}
\hline Mating. & Parents. & $Y$. & $p Y$. & $B A g$ or $B$. & $B$. & $\mathrm{Br}$. & pBrAg. & $p B$. & $p$ : \\
\hline \multirow[t]{2}{*}{$\begin{array}{l}200 \\
216 \\
514 \\
473\end{array}$} & \multirow[t]{2}{*}{$\begin{array}{l}1282 \times 1389 \ldots \ldots \ldots \ldots \\
1283 \times 1389 \ldots \ldots \ldots \ldots \\
\text { Unmarked } \times 4523 \ldots \ldots \\
\text { Unmarked } \times \text { unmarked. }\end{array}$} & $\begin{array}{l}1 \\
1 \\
2 \\
2\end{array}$ & $\begin{array}{l}1 \\
2 \\
2 \\
\cdots\end{array}$ & $\begin{array}{l}2 \\
\cdots \\
\cdots \\
\cdots\end{array}$ & $\begin{array}{l}3 \\
1 \\
\ldots\end{array}$ & $\begin{array}{l}\cdots \\
\cdots \\
\dddot{1}\end{array}$ & $\begin{array}{l}\cdots \\
\because \\
i\end{array}$ & $\begin{array}{l}\ddot{3} \\
\cdots\end{array}$ & $\begin{array}{l}1 \\
\cdots \\
\cdots \\
\cdots\end{array}$ \\
\hline & & 6 & 5 & 2 & $\dot{4}$ & 1 & 1 & 3 & 1 \\
\hline
\end{tabular}


Cross 127. Giving $Y, p Y, B A g, B, B r, p B$, and $H$.

\begin{tabular}{|c|c|c|c|c|c|c|c|c|}
\hline Mating. & Parents. & $Y$. & $p Y$. & $B A g$. & B. & Lrr. & $p B$. & W. \\
\hline \multirow[t]{2}{*}{$\begin{array}{l}501 \\
532\end{array}$} & \multirow[t]{2}{*}{$\begin{array}{l}\text { (a) } \text { unmarkerl } \times 3297 \ldots \\
\text { (b) unmarker! } \times 3297 \ldots\end{array}$} & $\begin{array}{l}1 \\
4\end{array}$ & $\begin{array}{l}1 \\
2\end{array}$ & 1 & 1 & 1 & 1 & $\frac{2}{2}$ \\
\hline & & j & 3 & 1 & 1 & 1 & 1 & 4 \\
\hline
\end{tabular}

Yellow $\times$ pink-eyed yellow, giving ints'nse and dilute dark-eyed and pink-eyed young.

Cross 12S. Giving $Y, p Y, d B A g$, and $p d B A g$.

\begin{tabular}{|c|cc|c|c|c|}
\hline Mating. & Parents. & Y. & $p Y$. & dBA $1 g$. & $p$ IBAg. \\
\hline 530 & Unmarked $\times 4152 \ldots$ & 1 & 2 & 1 & 1 \\
\hline
\end{tabular}

Cream $\times$ pink-eyed yellou, giving nothing but derk-eyed intense young.

Cross 129. Giving $Y^{r}$ and $B A g$.

\begin{tabular}{|c|c|c|c|}
\hline Mating. & Parents. & $Y$. & $B$ B g. \\
\hline 181 & $1223 \times 1074 \ldots$ & 3 & $\ddots$ \\
210 & $1223 \times 1064 \ldots$ & 14 & 1 \\
\hline & & 17 & 1 \\
\hline
\end{tabular}

In the following erosses, between yellow and non-yellow animals, equality of yellow and non-yellow young is to be expected. These matings, like the yellow $\times$ yellow mating just eited are planned chiefly to test the relation of yellow to non-yellow forms, not with an eye to producing any certain color variety.

Yellow $\times$ blach agouti, giving only dark-eyed intense young.

Cross 130. Giving $Y$ and $B A g$.

\begin{tabular}{|c|c|c|c|}
\hline Mating. & Parents. & Y. & B.ig. \\
\cline { 1 - 2 } 12 & $506 \times 530.5 \mathrm{~A} \ldots$ & 3 & 4 \\
24 & $530.1 \mathrm{~A} \times 630 \ldots$. & 1 & 7 \\
\hline & & 4 & 11 \\
\hline
\end{tabular}

Cross 131. Giving $Y, B A g$, and $W$.

\begin{tabular}{|c|c|c|c|c|}
\hline Niating. & Parents. & Y. & B.A $g$. & $W$ \\
\hline 15 & $608 \times 570 \ldots$ & 2 & 1 & 1 \\
\hline
\end{tabular}


Cross 132. Giving $Y, B A g, B r A g$, and $W$.

\begin{tabular}{|c|c|c|c|c|c|}
\hline Mating. & Parents. & I. & BAg. & BrAg. & H. \\
\hline 95 & $622 \times 624 \ldots$ & 2 & 1 & 1 & 1 \\
\hline
\end{tabular}

Yellow $\times$ black agouti, giving intense and dilute dart-eycd young.

Cross 133. Giving $Y, B A g$, and $d B A g$.

\begin{tabular}{|c|c|c|c|c|}
\hline Mating. & Parents. & $Y$. & BAg. & $d B A g$. \\
\hline 26 & $530.1 \mathrm{~A} \times 530.5 \mathrm{~A} \ldots$ & 1 & 5 & 1 \\
\hline
\end{tabular}

Yellow $\times$ black agouti, giving intense and dilute durk-eyed and pink-eyed young.

Cross 134. Giving $Y, d Y, p Y, B A g, d B A g, B r A g$, $d B r A g . B, p B$, and $B r$.

\begin{tabular}{|c|c|c|c|c|c|c|c|c|c|c|c|c|}
\hline Mating. & Parents. & $Y$. & $d Y^{\circ}$ & $p Y$. & $p d Y$. & $B A g$. & $d B . i g$. & BrAg. & $d B r+1 g$. & B. & $p B$. & $\mathrm{Br}$. \\
\hline \multirow[t]{2}{*}{$\begin{array}{l}459 \\
375\end{array}$} & \multirow[t]{2}{*}{$\begin{array}{l}\text { Unmarked } \times 3114 \ldots \\
\text { Unmarked } \times 3114-15\end{array}$} & $\begin{array}{l}11 \\
24\end{array}$ & $\begin{array}{l}1 \\
8\end{array}$ & 2 & . & $\begin{array}{r}4 \\
10\end{array}$ & $\begin{array}{l}3 \\
5\end{array}$ & $\frac{2}{8}$ & $\begin{array}{l}1 \\
1\end{array}$ & $\frac{2}{1}$ & 1 & 2 \\
\hline & & 35 & 9 & 2 & . & 14 & $S$ & 10 & 2 & 3 & 1 & 3 \\
\hline
\end{tabular}

Cream $\times$ black agouti, giving intense dark-eyed young only.

Cross 135. Giving cream and $B A g . *$

\begin{tabular}{|c|c|c|c|}
\hline Mating. & Parents. & Cream $Y$. & $B A g$. \\
\hline \multirow{3}{*}{$\begin{array}{l}443 \\
431\end{array}$} & \multirow{3}{*}{$\begin{array}{l}\text { Unmarked } \times \text { unmarked } \\
2108-09 \times 3917 \ldots \ldots \ldots \ldots\end{array}$} & 1 & 1 \\
\hline & & 2 & 1 \\
\hline & & 3 & 2 \\
\hline
\end{tabular}

*The black agoutis used in this cross were wild.

Cross 136. Giving $Y, B A g$, and $B$.

\begin{tabular}{|c|c|c|c|c|}
\hline Mating. & Parent. & Y. & BAg. & B. \\
\hline \multirow{2}{*}{265} & $917 \times 1550 \ldots \ldots$ & 3 & 2 & 1 \\
\hline
\end{tabular}

Cross 137. Giving $Y, B A g$, and $B r A g$.

\begin{tabular}{|c|c|c|c|c|}
\hline Mating. & Parents. & I. & BAtg. & BrAg. \\
\hline 534 & $4798 \times 4796 \ldots$ & 2 & 1 & 1 \\
\hline
\end{tabular}


Yellow $\times$ dilute black agouti, giving only intense dark-eysd young.

Cross 13S. (iiving $Y^{*}, B .1 g$, and BrAg.

\begin{tabular}{|c|c|c|c|c|}
\hline Nating. & Parents. & $Y$. & BAg. & BrAg. \\
& & & - & \\
322 & $215 t \times 1571 \ldots \ldots \ldots \ldots \ldots$ & 4 & 2 & 2 \\
412 & Cnmarked $\times$ inmarked ... & 2 & $\ldots$ & $\ldots$ \\
\hline & & 6 & 2 & 2 \\
\hline
\end{tabular}

Yellow $\times$ dilute black agouti, giving intense and dilute dark-eyed young.

Cross 139. Giving $Y, d Y, B A g, d B A g, B, d B, B r A g$, and $B r$.

\begin{tabular}{|c|c|c|c|c|c|c|c|c|c|}
\hline Mating. & Parents. & $Y$. & $d Y$. & $B A g$. & dBA. & B. & $d B$ & Br.Ag. & $B r$. \\
\hline \multirow[t]{2}{*}{$\begin{array}{l}438 \\
432 \\
409 \\
421\end{array}$} & $\begin{array}{l}4435 \times 2829 \ldots \ldots \\
4434-35 \times 2 \$ 29 \ldots \\
\text { Unmarked } \times 2829 \\
2352 \times 2 \$ 59 \ldots \ldots\end{array}$ & $\begin{array}{r}4 \\
4 \\
10 \\
2\end{array}$ & $\begin{array}{l}1 \\
1 \\
8 \\
\cdots\end{array}$ & $\begin{array}{l}\cdots \\
3 \\
\cdots\end{array}$ & $\begin{array}{l}\cdots \\
\cdots \\
1\end{array}$ & 1 & $\begin{array}{l}3 \\
\ldots\end{array}$ & $\begin{array}{l}3 \\
1\end{array}$ & $\begin{array}{c}1 \\
1 \\
\cdots\end{array}$ \\
\hline & & 20 & 10 & 3 & 1 & 1 & 3 & 4 & 2 \\
\hline
\end{tabular}

Cream $\times$ dilute black agouti, giving intenst and dilute dark-eyed young.

Cross 140. Giving $Y, d Y, d s Y$, and $B r$.

\begin{tabular}{|c|ccccc|} 
Mating. & Parents. & $Y$. & $M Y$ & $d s Y$. & $B r$ \\
373 & $2348 \times 2829$. & 4 & 2 & 1 & 1 \\
\hline
\end{tabular}

Cross 141. Giving $Y, B A g$, $d B r A g$, and $W$.

\begin{tabular}{|ccccc|c|}
\hline Mating. & Parents. & Y. & BAg. & ABrAg. & $W$. \\
402 & $2255 \times 1935 \ldots$ & 4 & 3 & 1 & 3 \\
\hline
\end{tabular}

Sooty yellow $\times$ dilute black agouti, giving intense dark-cyed and pink-eyed young.

Cross 142. Giving $Y, s Y, p Y, B A g$, and $p B A g$.

\begin{tabular}{|cccccccc|}
\hline Mating. & Parents. & $Y$. & $s Y$. & $p Y$. & BAg. & B or BAg. & PBAg. \\
346 & $2411 \times 2609 \ldots$ & 11 & 7 & 3 & 17 & 6 & 2 \\
\hline
\end{tabular}

Yellow $\times$ pink- yed black agouti, giving only intense durk-eyed young.

Cross 143. Giving $Y, B A g$, and $B$.

\begin{tabular}{|c|c|c|c|c|}
\hline Mating. & Parents. & $Y$. & BAg. & $B$. \\
\hline 76 & $509.2 \mathrm{~B} \times 409 \ldots$ & $\ddots$ & 9 & 6 \\
\hline is & $227 \times 412 \ldots \ldots$ & 9 & 8 & 5 \\
\hline & & & 17 & 11 \\
\hline
\end{tabular}


Yellow $\times$ pink-cycd black agouti, gicing interse and dilute durli-ryed young.

Cross 144. Giving $Y^{*}, B A g$, $I B A g$, and Br. $1 g$.

\begin{tabular}{|cccccc|}
\hline Mating. & Parents. & Y. & B.Ag. & HB.1g. & BrAg. \\
330 & $1667 \times 1576 \ldots$ & 9 & 2 & 1 & 3 \\
\hline
\end{tabular}

Ycllow $\times$ pink-eycd hlack agouti, giving intense and ditute dark-eyed and pink-cycd young. Cross 145. Giving $Y, B A g, d B A g, p B A y, B$, and $p B$.

\begin{tabular}{|cccccccc|}
\hline Mating. & Parents. & $Y$. & $B .4 g \cdot$ & $p B A g$. & HB.ig. & B. & $p B$. \\
\cline { 2 - 4 } & $1806 \times 2339 \ldots$ & $s$ & 1 & 1 & 1 & 2 & 1 \\
\hline
\end{tabular}

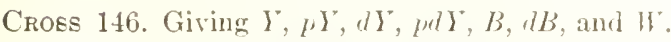

\begin{tabular}{|c|c|c|c|c|c|c|c|c|}
\hline Mating. & I'arents. & 1 & $p l$. & $d Y$ & $p d y$ & $B$. & $d B$ & Wr. \\
\hline 433 & $4051 \times$ unmarked & 5 & 4 & 1 & 1 & 2 & 2 & 4 \\
\hline
\end{tabular}

Yallow $\times$ black, gining only darli-eyed intense young.

Cross 147. Giving $I$ and $B A g$.

\begin{tabular}{|c|c|c|c|}
\hline Mating. & Parents. & $Y$. & $B A g$. \\
\hline \multirow{5}{*}{$\begin{array}{l}54 \\
49 \\
90 \\
61\end{array}$} & \multirow{5}{*}{$\begin{array}{l}502 \times 175 \ldots \ldots \\
185 \times 315 \ldots \ldots \\
\text { Ummarked } \times 502.513 . \\
502.313 \times \text { unmarked. }\end{array}$} & 5 & 2 \\
\hline & & 4 & 3 \\
\hline & & 2 & 5 \\
\hline & & 3 & 2 \\
\hline & & 14 & 12 \\
\hline
\end{tabular}

Croes 148. Giving only $Y$ and $B$.

\begin{tabular}{|c|c|c|c|}
\hline Mating. & Parents. & I. & $B$. \\
& & & \\
370 & $1977 \times 2046 \ldots \ldots \ldots$ & 3 & 2 \\
52 & $502.22 \mathrm{~B} \times 182 \ldots \ldots \ldots$ & 2 & 3 \\
53 & $509 \times 152 \ldots \ldots \ldots \ldots$ & 2 & 4 \\
88 & Unmarked $\times 321 \ldots \ldots$ &. & 2 \\
137 & $224 \times 347 \ldots \ldots .5 .1$ & 4 & 1 \\
40 & Unmarked $\times 505.1$. & $\ldots$ & 2 \\
& & 11 & 14 \\
& & & \\
\hline
\end{tabular}


C'ross 149. Giving $Y, B A g$, and $B$.

\begin{tabular}{|c|c|c|c|c|}
\hline Mating. & Parents. & $I^{\circ}$. & $B A g$. & $B$. \\
\hline \multirow[t]{2}{*}{$\begin{array}{r}35 \\
103\end{array}$} & \multirow[t]{2}{*}{$\begin{array}{l}207 \times 502.6 \mathrm{~B} . \\
225 \times 347 \ldots \ldots\end{array}$} & $\begin{array}{l}3 \\
2\end{array}$ & $\begin{array}{l}2 \\
1\end{array}$ & $\frac{2}{5}$ \\
\hline & & j & 3 & 7 \\
\hline
\end{tabular}

Cross 150. Giving $Y, B$, and $B r$.

\begin{tabular}{|c|c|c|c|c|}
\hline Mating. & Parents. & $I^{*}$. & $B$. & $B r$. \\
\hline \multirow[t]{2}{*}{$\begin{array}{l}117 \\
292 \\
238\end{array}$} & $\begin{array}{l}325 \times 323 \ldots \ldots \\
1662 \times 1660 \ldots \\
1662-63 \times 1660\end{array}$ & $\frac{2}{7}$ & $\begin{array}{l}5 \\
3 \\
3\end{array}$ & $\begin{array}{l}1 \\
1 \\
1\end{array}$ \\
\hline & & 16 & 11 & 3 \\
\hline
\end{tabular}

Cross 151. Giving $Y, B . A g$, and $W$.

\begin{tabular}{|c|c|c|c|c|}
\hline Mating. & Parents. & $Y$. & $B A g$. & II. \\
\hline \multirow[t]{2}{*}{$\begin{array}{l}46 \\
47 \\
17 \\
42 \\
43\end{array}$} & \multirow[t]{2}{*}{$\begin{array}{l}178 \times 530.01 \mathrm{~B} \\
509.3 \mathrm{~B} \times 17 \mathrm{~K} \\
206 \times 510 \ldots \ldots \\
201.1 \mathrm{~A} \times 511 . \\
201.2 \mathrm{~A} \times 511 .\end{array}$} & $\begin{array}{l}3 \\
3 \\
2 \\
2 \\
1\end{array}$ & $\begin{array}{l}1 \\
1 \\
3 \\
1 \\
1\end{array}$ & $\begin{array}{l}1 \\
3 \\
2 \\
3 \\
3\end{array}$ \\
\hline & & 11 & 7 & 12 \\
\hline
\end{tabular}

Cross 152. Giving $Y, B$, and $\Pi$.

\begin{tabular}{|c|c|c|c|c|}
\hline Mating. & Parents. & Y. & B. & H. \\
\hline 59 & Cnmarked $\times 141 \ldots$ & 4 & 1 & 1 \\
21 & $206 \times 514 \ldots \ldots \ldots$ & 3 & 2 & 3 \\
72 & $178 \times 320 \ldots \ldots \ldots$ & 6 & 8 & 3 \\
58 & $168-170-171 \times 185$. & 3 & 1 & 2 \\
51 & $206 \times 172 \ldots \ldots \ldots$ & 1 & 2 & 2 \\
\hline & & 17 & 14 & 11 \\
\hline
\end{tabular}

Cross 153. Giving $Y$, cream, $B A g, B r A g, B$, and $B r$.

\begin{tabular}{|c|c|c|c|c|c|c|c|}
\hline Mating. & Parents. & I. & Cream $Y$. & $B .1 \mathrm{~g}$. & $B r d g$. & $B$. & $B r$. \\
\hline \multirow[t]{2}{*}{$\begin{array}{r}73 \\
71 \\
108 \\
357 \\
91\end{array}$} & \multirow[t]{2}{*}{$\begin{array}{l}-67 \times \text { unmarked } \\
284 \times 182 . \ldots \\
\text { Unmarked } \times 323 . \\
1978 \times 2.106 \ldots \ldots \\
325 \times 502.513 \ldots\end{array}$} & $\begin{array}{r}5 \\
15 \\
7 \\
3 \\
5\end{array}$ & $\begin{array}{l}1 \\
\cdots \\
\cdots\end{array}$ & $\begin{array}{l}5 \\
\because \\
1 \\
3\end{array}$ & $\begin{array}{l}1 \\
\dddot{1} \\
1 \\
2\end{array}$ & $\begin{array}{l}\ddot{4} \\
\ddot{1} \\
\cdots\end{array}$ & $\begin{array}{l}\dddot{4} \\
3 \\
\cdots \\
\cdots\end{array}$ \\
\hline & & 35 & 1 & 9 & 5 & 5 & 7 \\
\hline
\end{tabular}




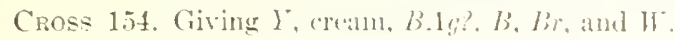

\begin{tabular}{|c|c|c|c|c|c|c|c|}
\hline Mating. & Parents. & 1. & Cream $Y$. & $B A g$ ir $B$ & bi. & $\mathrm{Br}$. & H. \\
\hline 57 & $152 \times 1.11$ & 4 & & & 3 & 1 & 1 \\
\hline 80 & $14 i \times 319 \ldots$ & 4 & & & 5 & 1 & I \\
\hline \multirow[t]{2}{*}{94} & $1.5 \times 34>\ldots$ & 9 & 3 & 1 & !) & 2 & 10 \\
\hline & & 17 & 3 & 1 & 17 & 4 & 12 \\
\hline
\end{tabular}

Cross 155. Giving I, B.1g, BrAt. B. and 17 .

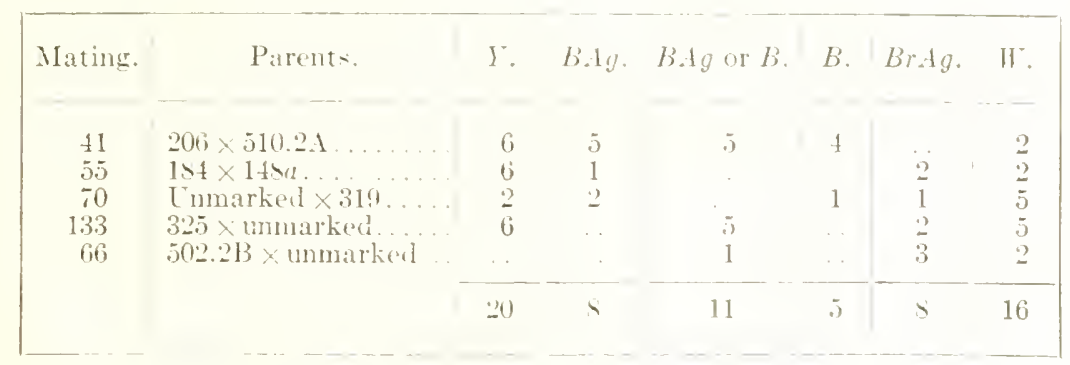

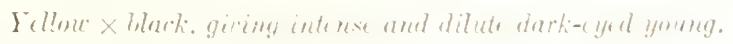

Cross 150 . Giving $1, B, b r$ and $d B$.

\begin{tabular}{|c|c|c|c|c|c|}
\hline Natins. & Parents. & $Y$ & $l i$. & $B i$. & $A B$. \\
\hline 276 & $16133 \times 1660$ & 2 & i) & 2 & 1 \\
\hline
\end{tabular}

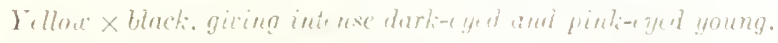

Cross 157. Giving $Y, p, b$, and $p l i$.

\begin{tabular}{|c|c|c|c|c|c|}
\hline Matiner. & Parent - & 1. & 115 & Is. & $p l$. \\
\hline $\begin{array}{l}341 \\
491 \\
456\end{array}$ & $\begin{array}{l}2195 \times 2197 \ldots \\
1 \text { nmater } \\
2803 \times 2945 \ldots\end{array}$ & $\frac{2}{5}$ & $\because$ & $\begin{array}{l}3 \\
6 \\
2\end{array}$ & $\begin{array}{l}1 \\
1 \\
1\end{array}$ \\
\hline & & 10) & 2 & 11 & 3 \\
\hline
\end{tabular}

Cross 158 . Giving $Y$, ream, $p), B, B r, p b$, and $p b r$.

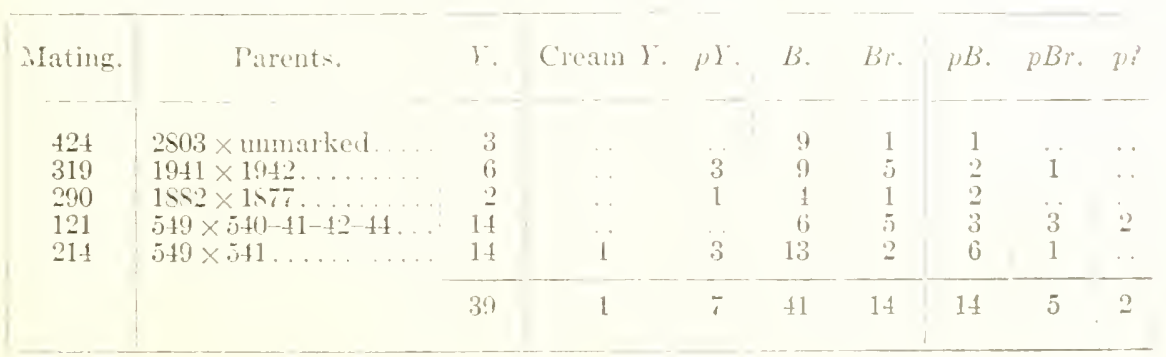


Cream $\times$ black, giming only inlense darli-eyrul young.

Ciross 159. (iving $Y, B$, and $B r$.

\begin{tabular}{|c|c|c|c|c|}
\hline Mating. & Parents. & $Y$. & b'. & $B r$. \\
\hline \multirow{2}{*}{$\begin{array}{l}217 \\
2 \times 5\end{array}$} & \multirow{2}{*}{$\begin{array}{l}\text { Unmarkend } \times 998 \\
29992 \times 949\end{array}$} & 3 & $\begin{array}{l}1 \\
2\end{array}$ & $\begin{array}{l}1 \\
2\end{array}$ \\
\hline & & 6 & 3 & 3 \\
\hline
\end{tabular}

Cunss 160. (Giving $Y, B, B r$, and $\|^{\circ}$.

\begin{tabular}{|cccccc|} 
Mating. Parents. & b. & B. & Br. & H. \\
$156 j$ & $325 \times 945 .$. & 11 & 3 & 10 & 7 \\
\hline
\end{tabular}

Cream $\times$ dilute bluck, giting only intense durli-eyed young.

Cross 161. Giving $Y$ and :

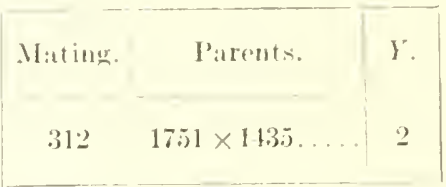

Yellou $\times$ ditute bark, giving intense and dilute dork-eyed young.

Cross 162. Giving $Y$, $d Y$, $d B$, and $d B r$.

\begin{tabular}{|c|cccc|c|}
\hline Mating. & l'arents. & $Y$. & $d Y$. & $d B$. & $d B r$. \\
\hline 145 & $4199 \times 4196 \ldots$ & 1 & 2 & 3 & 1 \\
\hline
\end{tabular}

Yellow $\times$ pink-ryed bluck, giving onty durk-eyed intense young.

C'ross 163. Giving $Y$ and $B$.

\begin{tabular}{|c|c|c|c|}
\hline Mating. & Parents. & $Y$. & $B$. \\
\hline 271 & $1639 \times 1587 \ldots$ & 2 & 1 \\
289 & $1666 \times 1610 \ldots$ & 5 & $\frac{5}{3}$ \\
307 & $2049 \times 1610 \ldots$ & 1 & 5 \\
& & 8 & 13 \\
\hline
\end{tabular}

Yellow $\times$ pink-eyed blach, gining intense dark-ryod and pink-eyed young. Cross 164. Giving $Y, B r$, and $p B$.

\begin{tabular}{|c|c|c|c|c|}
\hline Mating. & Pitrents. & Y. & Br. & $p B$. \\
309 & $2050 \times 2062 \ldots \ldots \ldots$ & 1 & 1 & 1 \\
\hline
\end{tabular}




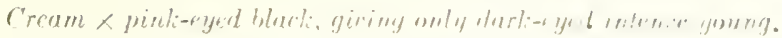

('irosis 16.5. Giving Y, croum, and b'.

\begin{tabular}{|c|c|c|c|c|}
\hline Mating. & P'urant- & $y$. & 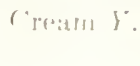 & Is. \\
\hline 2991 & \multirow{6}{*}{ 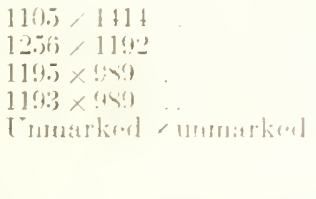 } & 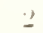 & & ; \\
\hline 1,80 & & 1i) & & $1 . j$ \\
\hline 201 & & 1 & $;$ & 5 \\
\hline 2.25 & & 7 & & 1 \\
\hline \multirow[t]{2}{*}{$\cdots$} & & $y$ & $\ddot{\prime}$ & 10) \\
\hline & & 24 & ,j & 37 \\
\hline
\end{tabular}

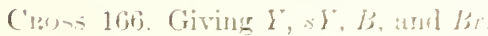

\begin{tabular}{|c|c|c|c|c|}
\hline Milling. & Parenta. & $i$ & $y$ & u \\
\hline 2() & $1111,1: 311$ & $t$ & 1 & 1 \\
\hline
\end{tabular}

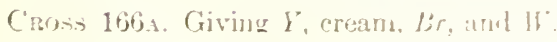

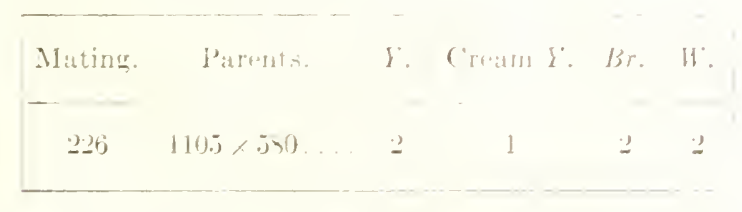

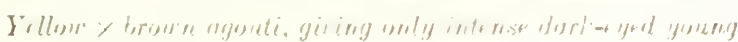

Cieosis 167. Giving $y$ and ls.1y.

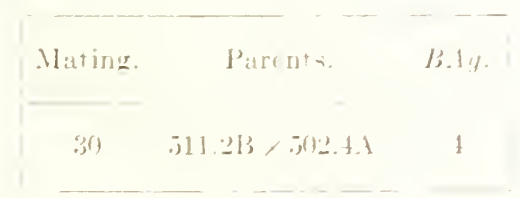

Corsis 169. Civing Y and birlg.

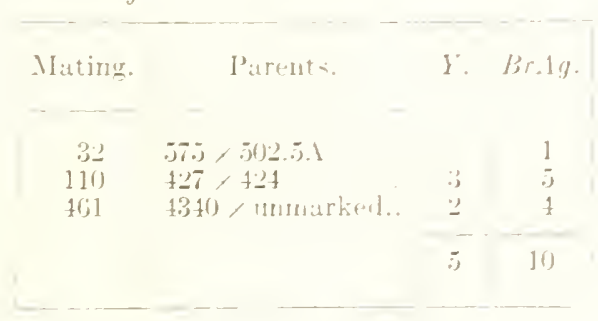

Censs 169. Civing $Y$, B.1y, and

\begin{tabular}{|c|c|c|c|c|}
\hline Matilus. & Purents. & $Y$. & $B .1 g$. & bi. \\
\hline 5$)$ & $511.11 / 140$. & i & 1 & 2 \\
\hline
\end{tabular}


Cross 170. Giving $Y, B r A g$, and $B r$.

\begin{tabular}{|c|c|c|c|c|}
\hline Mating. & Parents. & Y. & BrAg. & Br. \\
\hline 191 & $892 \times 895 \ldots \ldots$ & 2 & 3 & 1 \\
\hline
\end{tabular}

Cross 171. Giving $Y, B r A g$, and $W$.

\begin{tabular}{|c|c|c|c|c|}
\hline Mating. & Parents. & Y. & BrAg. & W. \\
\hline 75 & $170 \times 410 \ldots \ldots$ & 1 & 5 & 2 \\
\hline
\end{tabular}

Cross 172. Giving $Y, B r A g, B r$, and $W$.

\begin{tabular}{|c|c|c|c|c|c|}
\hline Mating. & Parents. & Y. & BrAg. & Br. & W. \\
\hline 176 & $\$ 91 \times 895 \ldots$ & 9 & 2 & 5 & 6 \\
\hline
\end{tabular}

Yellow $\times$ brown agouti, giving intense and dilute dark-eyed young.

Cross 173. Giving $Y, B A g, B r A g$, and $A B r A g$.

\begin{tabular}{c|cc|c|c|c|}
\hline Mating. & Parents. & $Y$. & BAg. & BrAg. & dBrAg. \\
\hline 69 & $171 \times+11 \ldots$ & 7 & 5 & 5 & 1 \\
\hline
\end{tabular}

Cross 174. Giving $Y, d Y$, and $d B r A g$.

\begin{tabular}{|c|cc|cc|}
\hline Mating. & Parents. & $Y$. & $d Y$. & $d B r A g$. \\
\hline 423 & $3414 \times 3413 \ldots$ & 1 & 2 & 4 \\
\hline
\end{tabular}

In the following matings the yellow parents were dilute, and of four different sorts, viz:

Dilute black-cyed yellow, $\mathrm{I}_{2} \mathrm{Br}_{2} B_{2} d_{2} P_{2} \mathrm{~A}_{2} R$;

Dilute black-cyed yellow, $Y_{2} B_{2} B_{2} d_{2} P_{2} R$;

Dilute brown-eyed yellow, $Y_{2} B_{2} r_{2} P_{2} A_{2} R$;

Dilute brown-eyed yellow, $Y_{2} \mathrm{Br}_{2} d_{2} P_{2} R$.

These four varieties are extremely diffieult, if not impossible, to tell from one another by superficial examination. The two brown-eyed types may, however, be distinguished at times by their eye-color, which is, as in the corresponding intense types, always brown. The following description will apply then to these four varieties:

Hyes black or brown, ears pink. Ventral hairs much the same as in the intense yellow type. Tail unpigmented. Dorsal hairs a dull heavy yellow with the characteristic washed-out appearance of all dilute forms. Hairs at the base of the ears and around the anus are indistinguishable from the rest of the coat. 
Dilute yellow $\times$ dilute yellow; giving only dilute dark-eycd young.

Cross 175. Giving $d Y$ and $d B .1 g$.

\begin{tabular}{|cccc|}
\hline Mating. & Parents. & $d Y$. & $d B A g$. \\
\hline 499 & Cnmarked $\times 3575 \ldots$ & 9 & 2 \\
\hline
\end{tabular}

Cross 176. Giving $d Y^{*}$ and $d B$.

\begin{tabular}{|ccc|c|}
\hline Mating. & Parents. & $d Y$. & $d B$. \\
& & & \\
& & & \\
\hline
\end{tabular}

Cross 177. Giving $d Y, d B A g$, and $d B r A g$.

\begin{tabular}{|c|c|c|c|c|}
\hline Mating. & Parents. & $d I^{\circ}$. & $A B .1 \mathrm{~g}$. & $A B r A g$ \\
\hline \multirow{4}{*}{$\begin{array}{l}382 \\
481 \\
482\end{array}$} & \multirow{4}{*}{$\begin{array}{l}3101 \times 2233 \\
\text { I mmarked } \times 1156 . \\
\text { Lnmarked } \times 1712 .\end{array}$} & $?$ & 2 & 3 \\
\hline & & 1.5 & $\delta$ & 1 \\
\hline & & 2.5 & 2 & 9 \\
\hline & & 49 & 12 & 16 \\
\hline
\end{tabular}

Cross 178. Giving $d Y$, $d B A g, d B r A g$, and $d B r$.

\begin{tabular}{|rc|ccc|c|}
\hline Mating. & Parent.. & dY. & dBA $g$. & dBr. $g$. & ABr. \\
\hline 484 & Inmarked $\times 1331$ & 8 & 1 & 3 & 3 \\
\hline
\end{tabular}

Cross 179. Giving $d Y, d B r .1 g$, and $W$.

\begin{tabular}{|cc|c|c|c|}
\hline Mating. & Parcnts. & A & ABrAg. & $W$. \\
\hdashline $4 \$ 3$ & $414 \pi \times 1146 \ldots$ & 4 & 2 & 3 \\
\hline
\end{tabular}

Cross 180. Giving $d Y, d B A g, d B r \cdot 1 g$, and $W^{r}$.

\begin{tabular}{|c|c|c|c|c|c|}
\hline Nating. & Parents. & $d Y$. & $d B A g$ & $d B r i g$. & II. \\
\hline 531 & Lnmarked $\times 1116$. & 9 & 1 & 2 & 4 \\
\hline
\end{tabular}

Dilute yellow $\times$ pink-eyed ycllow, giving intense and dilute dark-eyed young.

Cross 181. Giving $d Y, B A g, B, d B .1 g$, and $d B r A g$.

\begin{tabular}{|c|c|c|c|c|c|c|}
\hline Mating. & Parents. & $d Y$. & $B A g$. & $B$. & $\| B A g$. & $d B r i g$. \\
\hline 500 & Unmarked $\times 1152$. & 2 & 1 & 1 & 1 & 1 \\
\hline
\end{tabular}


Dilute yellow $\times$ pink-eyed yellox, giving intense and dilute dark-eyed and pink-eycd young. Cross 152. Giving $Y, p Y, d Y, p d Y, B A g, d B A g, B$, and $p B$.

\begin{tabular}{|c|c|c|c|c|c|c|c|c|c|c|}
\hline Mating. & Parents. & $Y$. & $p Y$. & $d Y$. & $p d Y$. & $B A g$. & $d B A g$. & B. & $p B$. & $B A g$ or $B$. \\
\hline \multirow[t]{2}{*}{$\begin{array}{l}515 \\
480 \\
467 \\
539\end{array}$} & \multirow[t]{2}{*}{$\begin{array}{l}\text { Unmarked } \times 4152 \\
\text { Unmarked } \times 3875 \\
4524 \times 1523 \ldots \\
\text { Unmarked } \times 4523\end{array}$} & $\begin{array}{l}2 \\
1 \\
2 \\
\cdots\end{array}$ & $\begin{array}{l}2 \\
3 \\
3\end{array}$ & $\begin{array}{l}3 \\
1 \\
1\end{array}$ & $\ddot{1}$ & $\begin{array}{l}2 \\
\cdots \\
\cdots \\
\cdots\end{array}$ & 1 & $\begin{array}{l}1 \\
\cdots \\
2\end{array}$ & $\ddot{1}$ & $\begin{array}{l}2 \\
\cdots \\
\cdots\end{array}$ \\
\hline & & 5 & $S$ & 5 & 3 & 2 & 1 & 3 & 1 & 2 \\
\hline
\end{tabular}

Dilute ycllow $\times$ pink-cyed dilute yellow, giring only dilute dark-cyed young.

Cross 183. Giving $d Y, d B A g$, and $d B$.

\begin{tabular}{|c|cc|c|c|}
\hline Mating. & Parents. & $d Y$. & $d B A g$. & $d B$. \\
\hdashline 512 & Unmarked $\times 3875 \ldots$ & 15 & $S$ & 2 \\
\hline
\end{tabular}

Dilide yellow $\times$ will black agouti, giving intonse dark-cycd young.

Cross 184. Giving $Y$ and ?

\begin{tabular}{|c|c|c|}
\hline Mating. & Parents. & $\%$ \\
\hline 523 & $4315 \times 5160-5161 \ldots$ & 1 \\
\hline
\end{tabular}

Dilute yellow $\times$ dilute black agouti, giving dilute dark-cycd young.

Cross 185. Giving $d Y$, $d s Y$, and $d B A g$.

\begin{tabular}{|c|c|cc|c|}
\hline Miating. & Parents. & $d Y$. & $d s Y$. & $d B A g$. \\
439 & $3553 \times 3876 \ldots \ldots$ & 7 & $\ddots$ & 5 \\
417 & $3554 \times 3875 \ldots \ldots$ & 5 & 1 & 3 \\
\hline & & 12 & 1 & $\delta$ \\
\hline
\end{tabular}

Dilute yellow $\times$ dilute broun agouti, giving only ditute dark-eycd young.

Cross 1@6. Giving $d Y, d B A g$, and $d B r A g$.

\begin{tabular}{|c|c|c|c|c|}
\hline Mating. & Parents. & $d Y$. & $d B A g$. & $d B r A g$. \\
\hline 450 & $4023-24 \times 4021-22 \ldots$ & 1 & 5 & 5 \\
427 & $4024 \times 4021-22 \ldots \ldots$ & 8 & $\ddots$ & 5 \\
431 & $4023 \times 4021-22 \ldots \ldots$ & 6 & 4 & 1 \\
343 & $2259 \times 2233 \ldots \ldots \ldots$ & 6 & 4 & 3 \\
\cline { 2 - 5 } & & 21 & 13 & 14 \\
\hline
\end{tabular}


Dilute sooty yellow $\times$ dilute brown agouti, giving dilute dark-eyed and pink-eyed young.

Cross 1s7. Giving $d s Y, p d Y$, $d B A g$, and $d B r A g$.

\begin{tabular}{|c|c|c|c|c|c|}
\hline Mating. & Parents. & $d s Y^{\prime}$. & $p d Y^{\prime}$. & $d B A g$. & $d B r A g$. \\
\hline $\begin{array}{c}490 \\
465\end{array}$ & $\begin{array}{l}4503 \times 4573 \ldots \ldots \ldots \\
\text { Unmarked } \times 4753 \ldots\end{array}$ & 3 & 1 & 1 & 1 \\
\hline & & 5 & 2 & 1 & 1 \\
\hline
\end{tabular}

In the following crosses, the yellow parents were pink-eyed, and of four different types, viz.:

Pink-eyed yellow, $\mathrm{K}_{2} \mathrm{Br}_{2} \mathrm{~B}_{2} D_{2} \mathrm{p}_{2} \mathrm{~A}_{2} R$;

Pink-eyed yellow, $Y_{2} B_{r_{2}} B_{2} D_{2} p_{2} R$;

Pink-eyed yellow, $\mathrm{Y}_{2} \mathrm{Br}_{2} \mathrm{D}_{2} p_{2} \mathrm{~A} \mathrm{R}_{2}$;

Pink-eyed yellow, $\mathrm{Y}_{2} \mathrm{Br}_{2} \mathrm{D}_{2} \mathrm{p}_{2} \mathrm{R}$.

The eyes of the two varieties last named contain only a small number of granules, all of which are brown. They are indistinguishable from the eyes of the first two varieties, which, however, contain black granules. The following description will serve for all four varieties:

Eyes elear teep pink. Ears pink and umpigmented. In every other way these pink-eyed types resemble elosely the dirk-eyed yellow types. They occur in all grades from a deep orange to light crean, as do the dark-eyed forms. Because of the reduction of black and brown granules sooty pink-eyed yellows are seldom if ever obtained.

Pink-eyed yellow $\times$ pink-eyed yellow, giring only intense pink-eyed young.

Cross 188. Giving $p Y, p B A g$, and $p B$.

\begin{tabular}{|c|c|c|c|c|c|}
\hline Mating. & Parents. & $p Y$. & $p B A g$. & $p B$. & $p ?$ \\
\hline $\begin{array}{l}155 \\
195 \\
160 \\
173 \\
113\end{array}$ & $\begin{aligned} 1066 & \times 1064 \ldots \\
801 & \times 1064 \ldots \\
1067 & \times 1064 \ldots \\
1074 & \times 563 \ldots \\
562 & \times 563 \ldots\end{aligned}$ & $\begin{array}{l}3 \\
2 \\
2 \\
2 \\
6\end{array}$ & $\ddot{1}$ & $\begin{array}{l}\cdots \\
\ddot{2} \\
\ddot{2} \\
2\end{array}$ & $\begin{array}{l}\dddot{1} \\
\dddot{2} \\
1\end{array}$ \\
\hline & & 15 & 9 & 4 & 4 \\
\hline
\end{tabular}

Pink-eyed yellow $\times$ pink-eyed yellow, giving intense and dilute pink-eyed young.

Cross 189. Giving $p Y, p d Y$, and $p d B$.

\begin{tabular}{|c|c|c|c|c|}
\hline Mating. & Parents. & $p I$. & $p d Y$. & $p d B$. \\
\hline 468 & Unmarked $\times 4523 \ldots$ & 1 & 1 & 1 \\
\hline
\end{tabular}

Pink-eyca yellow $\times$ pink-eyed dilute yellow, giving intense and dilute pink-eyed young.

Cross 190. Giving $p Y, p d Y, p B$, and $p d B$.

\begin{tabular}{|c|c|c|c|c|c|c|c|}
\hline Mating. & Parents. & $p Y$. & $p d Y$ & $p B$. & $p d B$. & $p B$ or $p d B$. & $p ?$ \\
\hline 351 & $2342 \times 2343 \ldots$ & 13 & 1 & 1 & 2 & 3 & 2 \\
\hline
\end{tabular}


Pink-eyed yellow $\times$ black agouti, giving intense dark-eyed and pink-eyed young.

Cross 191. Giving $Y, p Y, B A g$, and $B$.

\begin{tabular}{|c|c|c|c|c|c|c|}
\hline Mating. & Parents. & $Y$. & $p Y$. & $B .1 g$. & $B$. & Dark-eyed. \\
\hline 126 & $414 \times 563$. & 8 & 1 & 5 & 5 & 2 \\
\hline
\end{tabular}

Pink-eyed yellow $\times$ dilute black, giving intense and dilute dark-e yed and pink-eyed young. Cross 191A. (iiving $Y, p Y, B$, dL or $d E A g, p d B A g$.

\begin{tabular}{|c|c|c|c|c|c|c|c|}
\hline Mating. & Parenti. & $Y$. & $p Y$ & B. & $d B$ or $d B A g$. & $p d B A g$. & $p ?$ \\
\hline 254 & $685 \times 1435 \ldots$ & 1 & 2 & 3 & 1 & 3 & 1 \\
\hline
\end{tabular}

Pinli-eyed yellow $\times$ broun, giving intense darli-eyed young.

Cross 192. Giving $Y$ and B.Ag.

\begin{tabular}{|c|c|c|c|}
\hline Mating. & Parents. & Y. & BAg. \\
\hline 201 & $1489 \times 1+37 \ldots$ & 5 & 3 \\
\hline
\end{tabular}

Pink-eyed yellow $\times$ pink-eyed black agouli, giving only pink-eyed inlense young. Cross 193. Giving $p Y$ and $p B A g$.

\begin{tabular}{|r|r|r|r|r|}
\hline Mating. & Parents. & $p Y$. & $p B A g$. & $p ?$ \\
\hline 79 & $413 \times 412 \ldots \ldots \ldots$ & 16 & 14 & $\ldots$ \\
167 & $1062 \times 1065 \ldots \ldots$ & 2 & 4 & 3 \\
157 & $1060 \times 1065 \ldots \ldots$ & 3 & 4 & 3 \\
& & 19 & 22 & 3 \\
\hline
\end{tabular}

Cross 194. Giving $p Y, p B A g$, and $p B$.

\begin{tabular}{|c|c|c|c|c|}
\hline Mating. & Parents. & $p Y$. & $p B A g$. & $p B$. \\
\hline 102 & $55 \pi \times 563 \ldots \ldots$ & 23 & $\mathrm{~S}$ & 2 \\
\hline
\end{tabular}

Pinli-eyed yellow $\times$ pinti-eyed brown agouli, giring only pinli-eyed intense young. Cross 19j. Giving $p Y^{\prime}$ and $p B A g$.

\begin{tabular}{|c|c|c|c|}
\hline Mating. & Parents. & $p Y$. & $p B A g$. \\
\cline { 1 - 2 } 194 & $139 i \times 14+1 \ldots$ & 3 & 2 \\
\hline
\end{tabular}


Pink-eyod yellow $\times$ pink-eyed black, giring only intense pink-eyed young.

Cross 196. (iiving $p B A g$ and $p Y^{2}$ ?

\begin{tabular}{rcc|}
\hline Mating. & Parents. & $p B .1 \mathrm{~g}$. \\
237 & $684 \times 763 \ldots$ & 3 \\
\hline
\end{tabular}

In the following croszes the vellow parents woukd fall into one of the four following classes:

Pink-eyed dilute yellow, $Y_{2} B r_{2} B d_{2} p_{2} A_{2} R$;

Pink-eyed dilute yellow, $Y_{2} B r_{2} B_{2} d_{2} p_{2} R$ :

Pink-eyed dilute yellow, $Y_{2} B r_{2} p_{2} A R_{2}$;

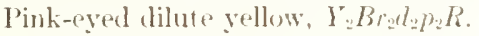

These four types, as in the intense pink-eyed forms, are indistinguishable from one another by superficial examination.

Eyes pink, otherwise indistinguishable from the dark-eyed dilute yellows already described.

No case of a pink-eyed dilute sooty yellow has been reeorded in these experiments.

Pink-eyed dilute yellowe $x$ dilute block agouli, giving diluk dorli-eryed and dilute pink-eyed young,

Cross 197. Giving $d Y, p l Y$, $d B A g, p d B A g, d B, p d B$, $d B r A g$, and $d B r$.

\begin{tabular}{|c|c|c|c|c|c|c|c|c|c|c|}
\hline Mating. & Parents. & $d Y$. & $m i S$. & $d B .1 g$. & $p d B . t g$. & $d B$. & $m i B$. & dBrag. & $d B r$. & $p d ?$ \\
\hline \multirow[t]{2}{*}{$\begin{array}{l}435 \\
425 \\
430\end{array}$} & \multirow[t]{2}{*}{$\begin{array}{l}\text { Ynmarket } \times 2458 . \\
3493 \times 2458 \ldots \ldots \\
3490 \times 2455 \ldots \ldots\end{array}$} & $\begin{array}{l}3 \\
1 \\
4\end{array}$ & $\begin{array}{l}5 \\
3 \\
4\end{array}$ & $\begin{array}{l}2 \\
1 \\
1\end{array}$ & $\begin{array}{l}1 \\
1 \\
3\end{array}$ & 1 & 3 & $\begin{array}{l}1 \\
\text {. }\end{array}$ & $\begin{array}{l}1 \\
\cdots \\
\cdots\end{array}$ & $\begin{array}{l}\cdots \\
\because\end{array}$ \\
\hline & & 8 & 12 & 4 & j) & 1 & 7 & 1 & 1 & 1 \\
\hline
\end{tabular}

Pink-eyed dilute yellow $\times$ black, giving intense and ditute darli-eyed and pink-eyed young.

Cross 19S. Giving $Y, p Y^{*}, \mu l Y^{*}, B, p B$, and $d B$.

\begin{tabular}{|c|c|c|c|c|c|c|c|c|}
\hline Mlating. & Parents. & Y. & $p Y$. & $p d Y$. & $B$. & $p B$. & $d B$. & $p ?$ \\
\hline 359 & $2345 \times 2343 \ldots$ & 4 & 5 & 1 & 4 & 3 & 2 & 1 \\
\hline
\end{tabular}

We may now consider a few tests of albinos which have been made. 1 ll of these seem to show that albinos may be potentially any of the 32 color varieties alrealy mentioned or any of their heterozygous combinations. None of the following allinos were tested for dilution and therefore they are treated as intense in their formulie, though if the proper test was made they might not turn out so. 
Cross 199.

Albino $\times$ pink-eyed broun.

\begin{tabular}{|c|c|c|c|c|c|c|c|c|c|}
\hline Mating. & Parents. & $Y$ & $B$. & BrAg. & $B r$. & $p B$. & pBrAg. & $p B r$. & $\begin{array}{l}\text { Formula of } \\
\text { albino parent. }\end{array}$ \\
\hline $\begin{array}{l}517 \\
536 \\
458 \\
540 \\
466 \\
518 \\
498 \\
170 \\
516 \\
497 \\
478 \\
508 \\
705 \\
429 \\
575\end{array}$ & 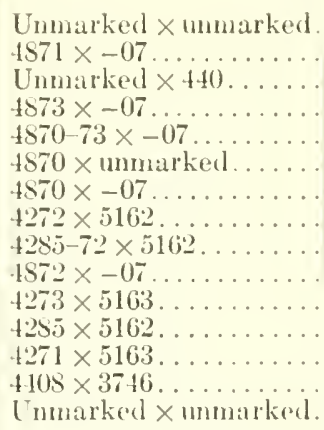 & $\begin{array}{l}\cdots \\
\cdots \\
\cdots \\
\cdots \\
\cdots \\
\cdots \\
\cdots \\
\cdots \\
\cdots \\
\because \\
2 \\
2\end{array}$ & $\begin{array}{l}\cdots \\
\cdots \\
4 \\
3 \\
4 \\
3 \\
\cdots \\
\because \\
\cdots \\
\cdots \\
\because \\
1\end{array}$ & $\begin{array}{l}\cdots \\
\cdots \\
\cdots \\
\cdots \\
\cdots \\
\cdots \\
\cdots \\
\cdots \\
\cdots \\
\cdots \\
\cdots \\
\cdots \\
\cdots\end{array}$ & $\begin{array}{l}8 \\
7 \\
6 \\
1 \\
9 \\
3 \\
1 \\
6 \\
5 \\
1 \\
\cdots \\
\cdots \\
2 \\
2 \\
2\end{array}$ & $\begin{array}{l}\cdots \\
\cdots \\
\cdots \\
\cdots \\
\cdots \\
\cdots \\
\cdots \\
\ddot{2} \\
\cdots \\
\cdots \\
\cdots \\
\cdots\end{array}$ & $\begin{array}{l}\cdots \\
\cdots \\
\cdots \\
\cdots \\
\cdots \\
\cdots \\
2 \\
\ddot{8} \\
3 \\
5 \\
\cdots \\
\cdots\end{array}$ & $\begin{array}{l}\cdots \\
\cdots \\
\cdots \\
\cdots \\
\cdots \\
3 \\
6 \\
2 \\
7 \\
3 \\
\cdots \\
\cdots\end{array}$ & 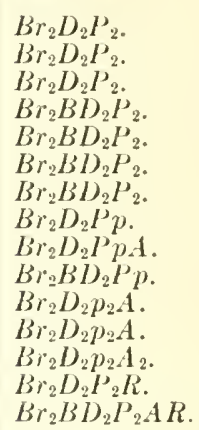 \\
\hline
\end{tabular}

A sinall number of more aecurate tests of albinos follow:

Cross 200 .

Albinos $\times$ pink-eyed dilute brown.

\begin{tabular}{|c|c|c|}
\hline Mating. & Parents. & $d B r$. \\
\hline 614 & Unmarked $\times 7551$ albino..... & 4 \\
626 & Unmarked $\times 7865$ albino..... & 15 \\
& & 22 \\
& & \\
\hline
\end{tabular}

Both 7551 and 7868 albiros turned out potentially homozygous dilute brown animals.

Two crosses between homozygous dilute brown animals earrying albinism, and 7868 albino, together with another all,ino (7748) of similar constitution, follow:

Cross 201.

\begin{tabular}{|c|c|c|c|}
\hline Mating. & Parents. & $d B r$. & $W$. \\
628 & 7749 dil. br. $\times 7748$ albino.... & 6 & 4 \\
$63 \pi$ & 7677 dil. br. $\times 7868$ albino... & 2 & 7 \\
\hline & & 8 & 11 \\
\hline
\end{tabular}

The expectation is equality of white and dilute brown young.

The following ease may in one sense be considered as uneonformable. It seens probable, however, that the aninal recorded as yollow was a dilute form, for the experiment oceurred early in the series (1907) before I had learned to recognize dilute animals by sight when young. This animal did not live more than two weeks and conld not therefore be tested by breeding.

Cross 202.

Pink-eyed black agouti $\times$ brown.

\begin{tabular}{|c|c|c|c|c|}
\hline Mating. & Parents. & $Y ?$ & B.Ag. & B. \\
\cline { 1 - 2 } 77 & $415 \times 409 \ldots$ & $* 1$ & 3 & 1 \\
\hline
\end{tabular}

* Probible incorrect classification. 


\section{BIBLIOGRAPHY.}

Alles, G. M., 1904. The heredity of coat color in mice. I'roc. Am. Acad. Arts and Sci., vol. 40, No. 2, pp. 61-163.

Bateson, W., 1903. The present state of knowledge of colour-heredity in mice and rats. Proc. Zool. Soc., vol. 2, pu. 71-78.

1909. Mendel's prineiples of heredity. Cambridge (Eng.) University Press, $396 \mathrm{pp}$.

Castle, W. E., 1905. Heredity of coat characters in guinea-pigs and rabbits. Carnegic Institution of Washington Publication No. 23, 78 pr., 6 plates.

1906. Yellow mice and gametic purity. Science, N. S., vol. 24, pp. 275-280.

1907a. On a case of reversion induced by cross-brecling and its fixation. Science, N. S., vol. 25, pp. 151-153.

$1907 b$. Color varieties of rabbits and other rodents, their origin and inheritance. Science, N. S., vol. 26, pp. 287-291.

1909. Studies of inheritance in rabbits. Carnegie Institution of Washington Publication No. 114, 68 pp., 4 plates.

1912a. On the origin of a pink-eyed guinca-pig with colored coat. Science, N. S.. vol. 35 , pp. 508-510.

1912b. On the origin of an albino race of deer-mouse. Sieience, N. S., vol. 35, pp. 346-348.

1912c. The inconstancy of unit characters. Am. Nat., rol. 46, pp. 351-362.

1912d. On the inheritance of the tri-color eoat in guinea-pigs and its relation to Galton's Law of Ancestral Heredity. Am. Nat., vol. 46, pp. 437-140.

Castle, W. E., and Little, C. C., 1909. The peculiar inheritance of pink eyes among colored mice. Scienee, N. S., vol. 30, pp. 313-314.

-1910. On a modified mendelian ratio among yellow mice. Scienec, N. S., rol. 32, pp. 868-870.

Castle, W. E. and MacCurdy, H. (See MacCurdy, H.)

Crampe, 1883. Zuchtsversuche mit zahmen Wanderratten, Landwirths. Jahrb., xir, p. 389.

1884. Second paper, Landwirths. Jahrb., xıI, p. 699.

Cuе́кот, L., 1902. La loi de Mendel et l'hérédité de la pigmentation chez les souris. Arch. Zool. Exp. et Gén. [3], vol. 10, Notes et revue, p. xxvi1.

1903. 2me note. Arch. Zool. Exp. et Gén. [4], vol. 1, Notes et revuc, p. xxxi11.

1904. 3me note. Ibid., Notes et revue [4], vol. 2, pp. XLV-LYI.

1905. 4me note. Ibid., Notes et revue [4], vol. 3, pp. cxxiII-cxxxII.

1907. 5me note. Ibid., Notes et revue [4], vol. 5, p. 1.

1908. 6me note. Sur quelque anomalies apparentes de proportions mendéliennes. Ibid. [4], vol. 6, Notes et revue, pp. viI-xv.

1911. 7me note, Les déterminants de la coulcur chez les souris, étude comparative. Ibid., Notes et revie [4], vol. 8, pp. xL-LVI.

Darbismire, A. D., 1902, 1903 . Notes on the results of crossing Japanese waltzing mice with European races, Biometrika, 11, pp. 101-104. Ibid., pp. 165-173, pp. $282-285$.

-1904. [Second paper], Biometrika, III, pp. 1-51.

Davenport, C. B., 1904. Color inheritance in mice. Science, N. S., rol. 19, pp. 110-114.

Doncaster, L., 1906. On the inheritance of coat colour in rats. Proc. Camb. Phil. Soc., vol. 13 , pp. $215-227$.

Derham, F. M., 1908. A preliminary account of the inheritance of coat colour in mice. Rep. Evol. Comm., 4, p. 41.

1911. Further experiments on the inheritance of coat colour in mice. Journ. Genet. vol. 1, pp. 159-178.

East, E. M., and Hayes, H. K., 1911. Inheritance in maize. Conn. Agri. Exp. Station, Bull. No. 167. 
Gortser, 1R. A., 1911a. Studies on Nelanin 1V. Am. Nat., vol. 45, pp. 743-753. 1911b. On Melanin. Biochem. Bull., vol. 1, pp. 207-215.

Gualta, G. von, 189S. Versuche mit Kreuzungen von versehiedenen Rassen des Hausmaus. Ber. Naturf. Ges. Freiburg, Bd. 10, p. 317.

- 1900. Zweite Mit theilung über Versuche mit Kireuzungen von versehiedenen Rassen des Hausmaus. Ibid., Bel. 11, p. 131.

If nzs, C. C., 1905. Experimental studles on heredity in rabbits. Limn. Soc. Journ. Zool., vol. 29, p. $2 \times 3$.

Keeble, F., and Arustrox(i, E. F., 1912. The rôle of oxydases in the formation of the anthocyan pigments of plants. Journ. Genetics, vol. 2, No. 3, pp. 2i -306.

Littre, C. C., 1911a. The "dilute" forms of yellow inice. Science, N. S., vol. 33, pp. $896-897$.

- 1911b. The influence of heredity and of environment in determining the coat colors in mice. Science, N. S., vol. 34 , p. 563.

-1912. Yellow and agouti factors in mice not associated. Am. Nat., vol. 46, pp. 491-193.

MacCurdy, HI., and C.stue, W. E., 1907. Sclection and cross-breceling in relation to the inheritance of coat-pigment and coat-patterns in rats and guinca-pigs. Carnegic Institution of Washington Publication No. 70, 50 pp., 2 plates.

Morgax, T. H., 1911 . The influence of heredity and of environment in determining the coat color in mice. Annals N. Y. Acad. of Sci., vol. 21, pp. 87-117, 3 plates.

-1911b. An attempt to analyze the constitution of the chromosomes on the basis of sex-limited inheritaner in Drosophila. Journ. Exp. Zool., vol. 11,pp. 365-412, 1 plate.

-1911c. Moulting and change of color of coat in mice. Science, N. S., vol. 34, p. 918.

Mudge, G. P., 190S $\pi$. On the hereditary transmission of ecrtain coat characters in rats. Proc. Roy. Soc., Series B, vol. 80, pp. 97-121.

-1908b. [Second paper, same title.] Proc. Roy. Soc., Scrics B, vol. 80, pp. 388-393.

1909a. Note on the chemical nature of albinism. Proc. Physiol. Soc., March 27, p. Lxvil.

-1909b. Further note on the chemical nature of albinism. Proc. Physiol. Soc., Oetober 23 , p. xrin.

Plate, L., 1910. Die Erbformeln der Farbenrassen von Mus musculus. Zool. Anz., vol. 35, No. 20, pp. 634-640.

RiddLe, O., 1909. Our knowledge of mclanin color formation and its bearing on the Mendclian description. Biol. Bull., vol. 16, pp. 316-351.

Sturtevant, A. H., 1912. Is there association between the ycllow and agouti factors in mice? Am. Nat., vol. 46, pp. 368-371. 

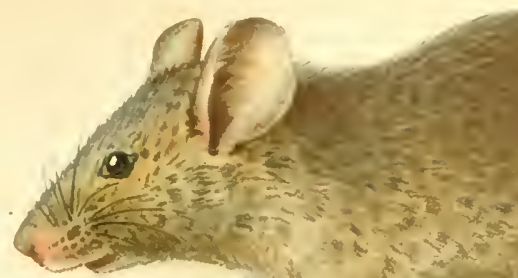

PLATE 1.
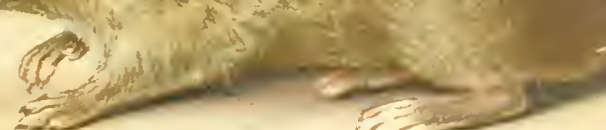

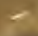

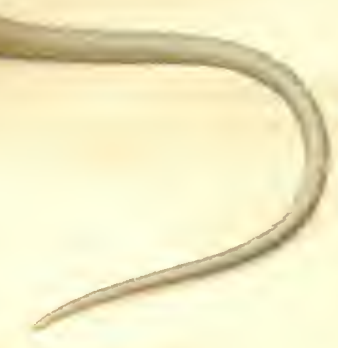

(2)
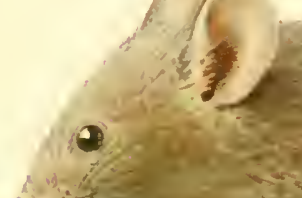

$\frac{1}{10}$
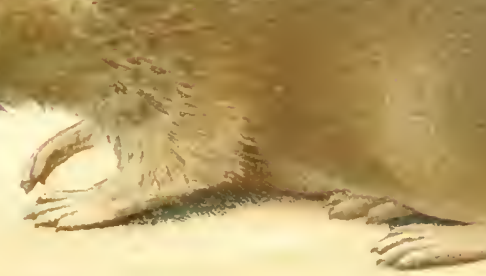

(4)
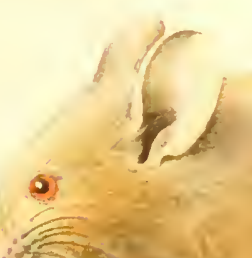

$\sum_{\infty \rightarrow \infty}$
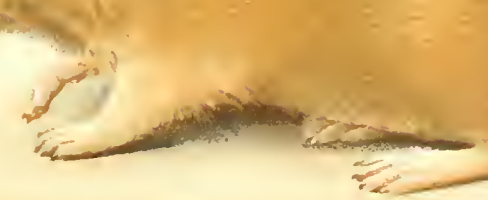

9

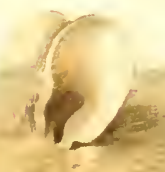

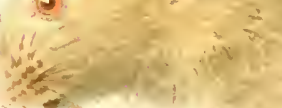

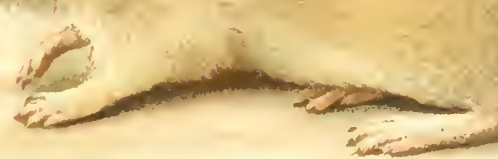

2

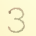

1. Wild type Black Agouti (Mus musculus), YBrBDPA

2. Dilute Black Agouti, YBrBdPA.

3. Pink-eyed Black Agouti, YBrBDpA.

4. Pink-eyed dilute Black Agouti, YBrBdpA.

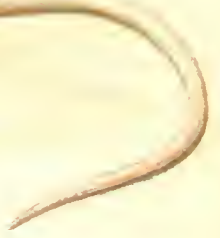

4

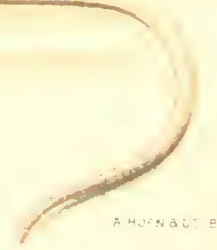




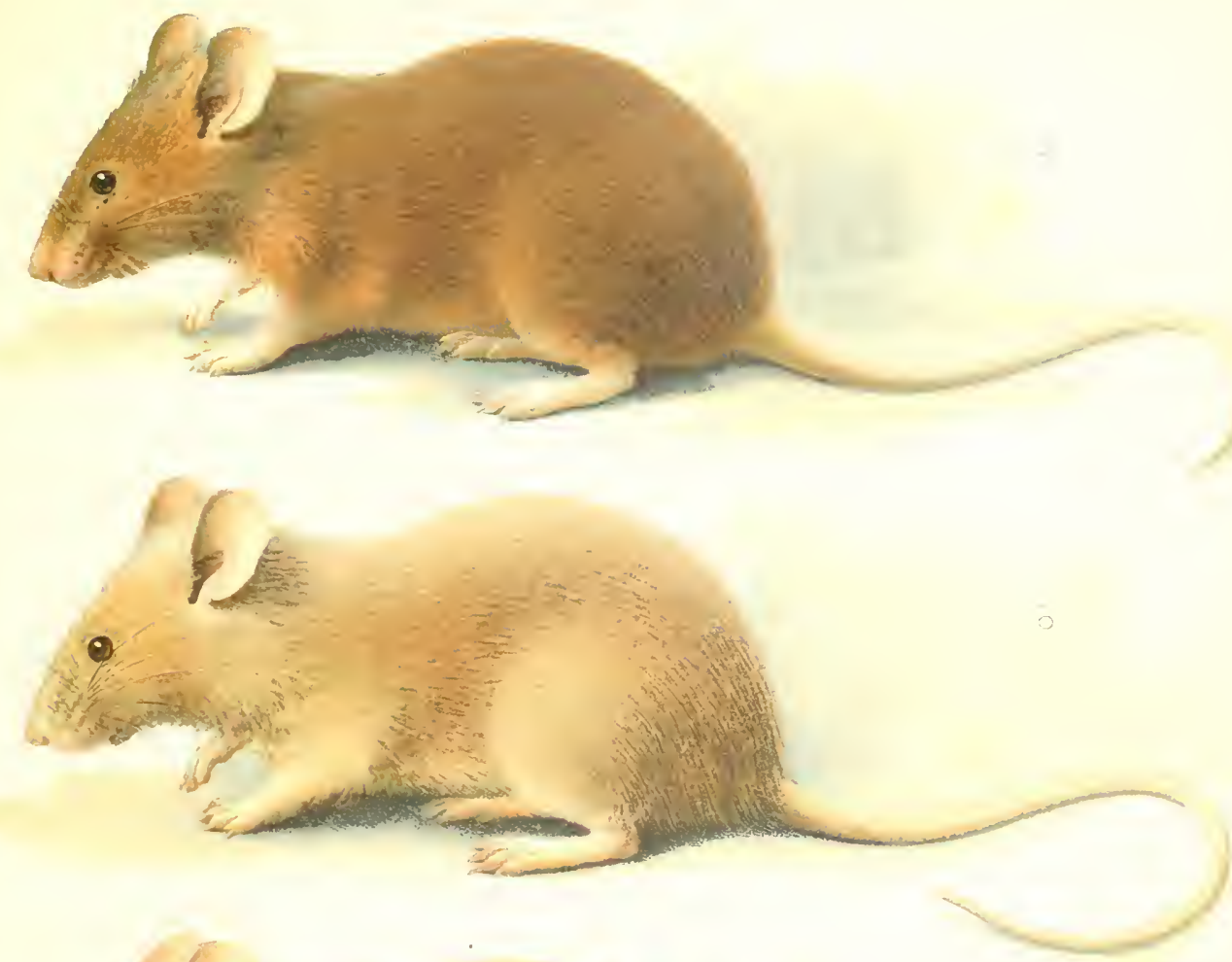

(9)

3

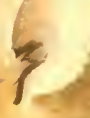

8
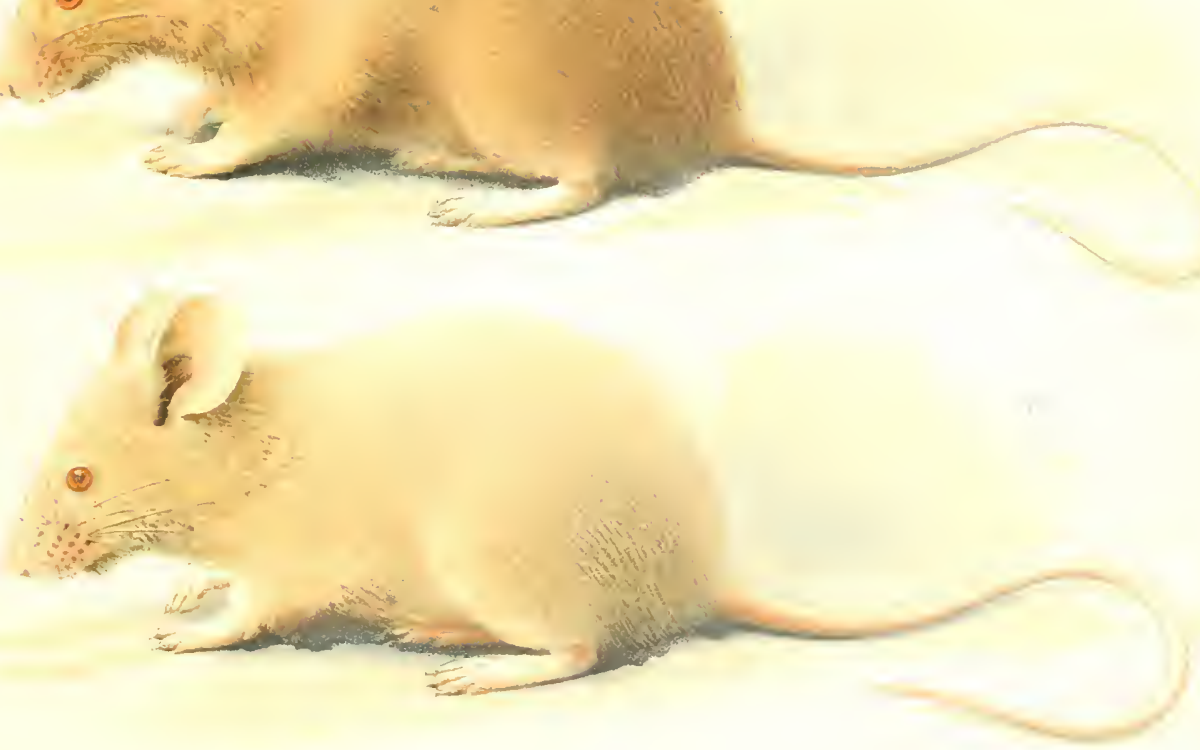

5. Brown Agoutı, YBrDPA.

6. Dilute Brown Agouti, YBrdPA.

7. Pink.eyed Brown Agouti, YBrDpA.

8. Pink-eyed dilute Brown Agouti, YBrdpA 


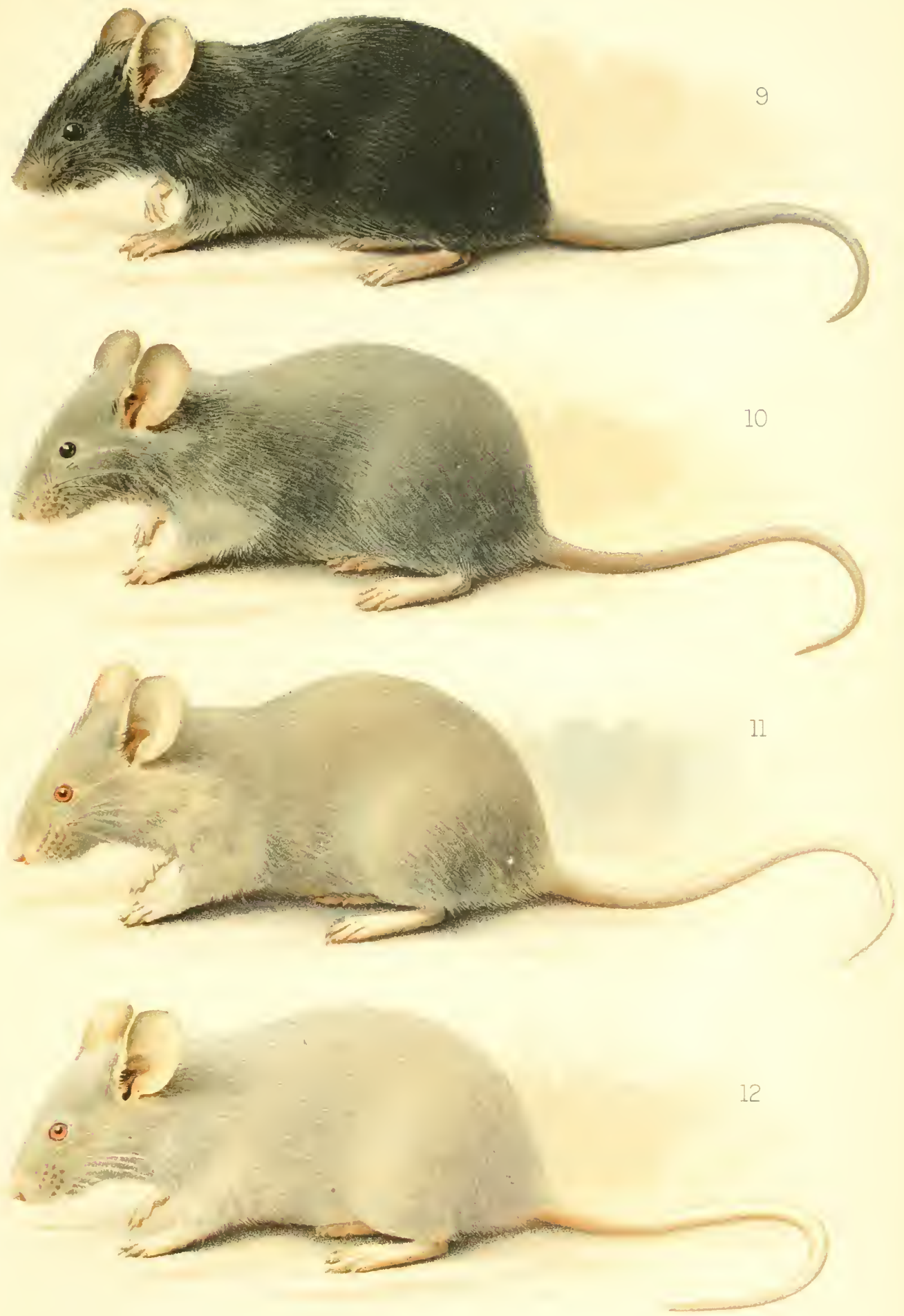

9. Black, YBrBDP.

10. Dilute Black, YBrBdP.

11. Pink-eyed Black, YBrBDp.

12. Pink-eyed dilute Black, YBrBdp. 
. 


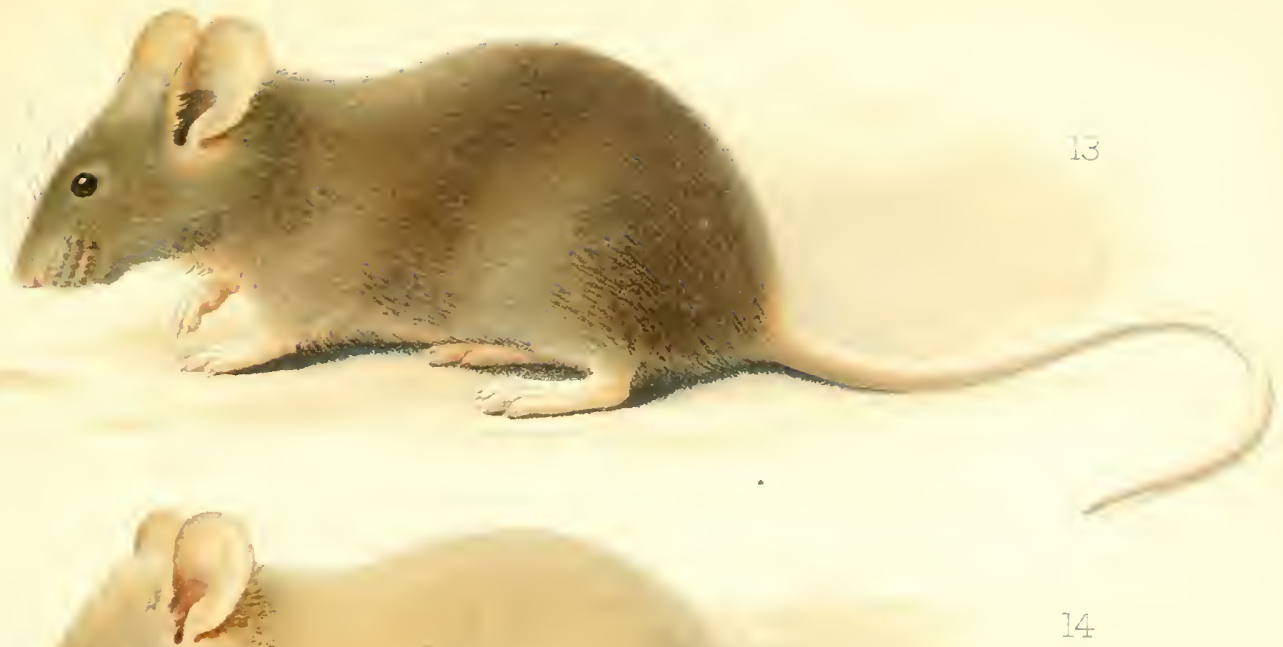

-
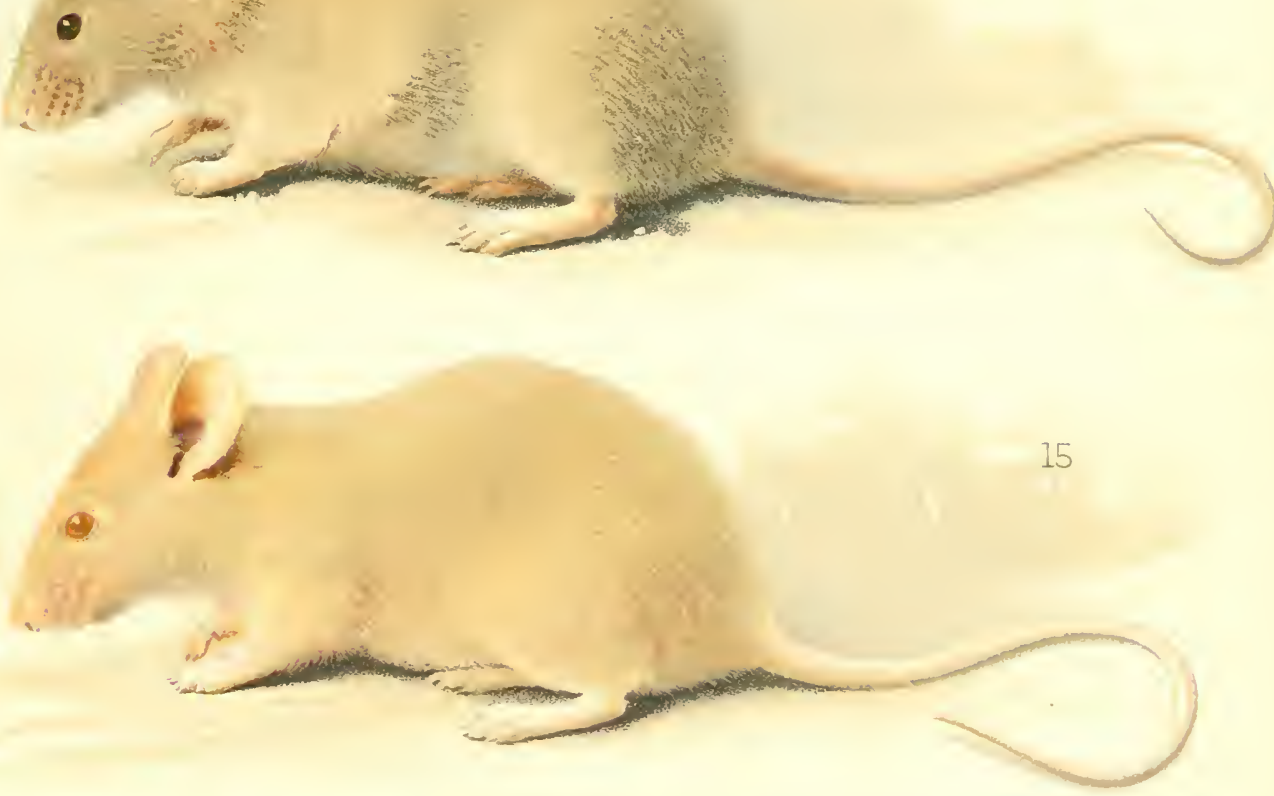

(1)

and

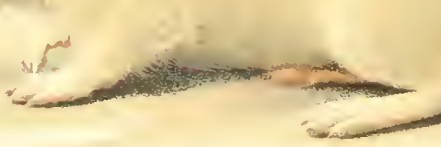

13. Brown, YBrDPr.

14. Dilute Brown, YBrdP

15. Pink-eyed Brown, YBrDp.

16. Pink-eyed dilute Brown, YBrdp. 



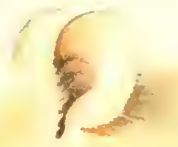

e

a
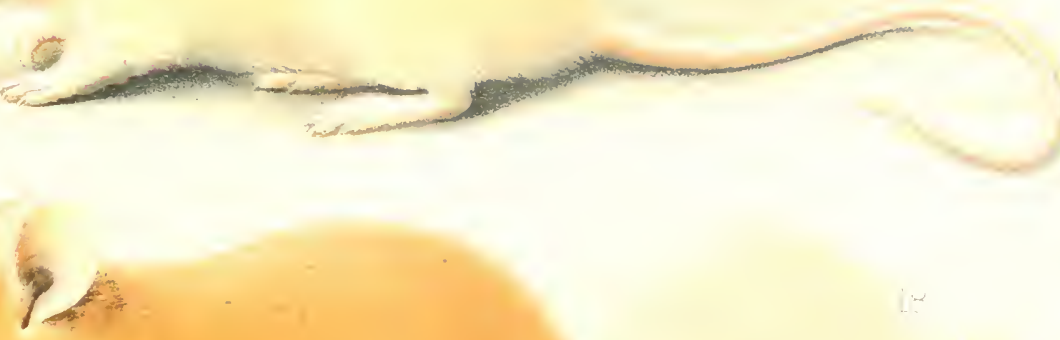

c

s.
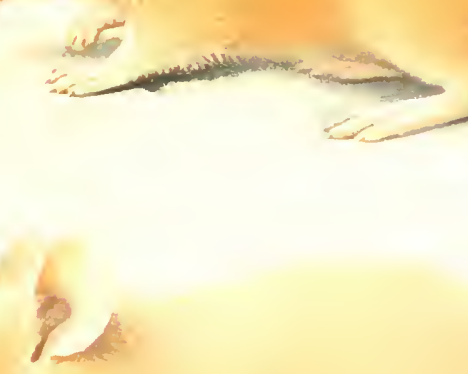

\section{-}
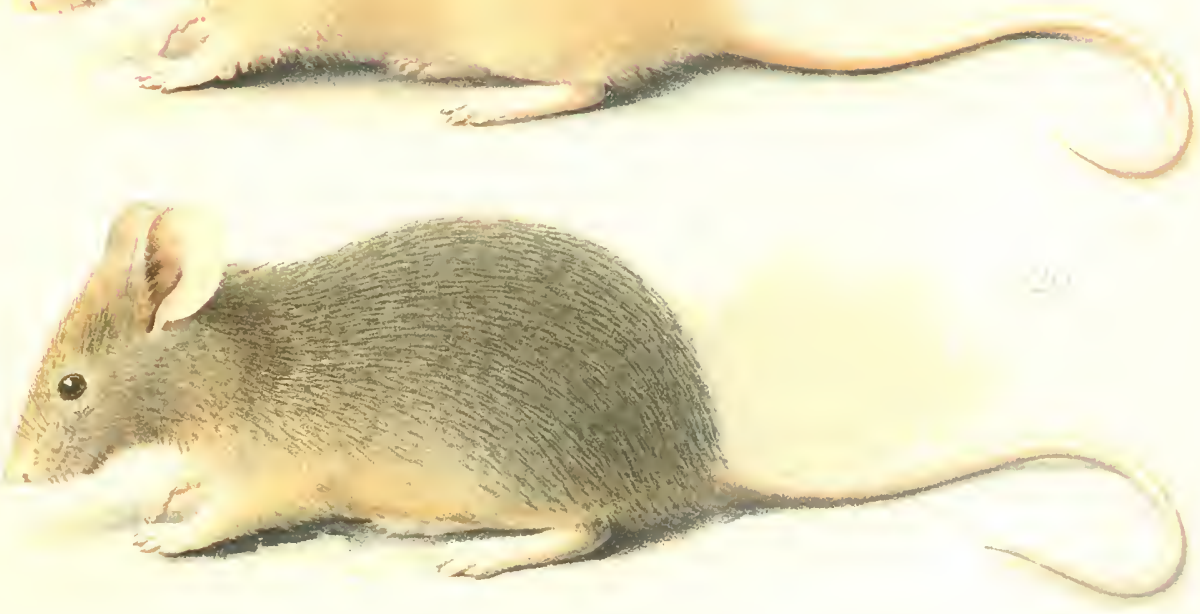

17. Black-eyed Cream (Yellow), YBrBDPR

18. Brown.eyed Yellow, YBrDPR.

19. Dilute Brown-eyed Yellow, YBrdPR.

20. Sooty Yellow, YBrDPR. 




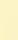


in Gastle, Nilizam Drrest

एदह 5

Bioles.

PLEASE DO NOT REMOVE

CARDS OR SLIPS FROM THIS POCKET

UNIVERSITY OF TORONTO LIBRARY 
